\title{
Some Overlooked Sources of the Elements of Theology: The Noetic Triad, Epistrophé, Apokatastasis, Bodies, God "All in All" and the Possible Reception of Origenian Themes
}

\author{
Ilaria Ramelli \\ Catholic University of Sacred Heart, Milano / Durham University
}

Proclus developed a system of Triads, in which he expanded the Plotinian protological Triad (One-Nous-Soul) through the Noetic Triad (Being-Life-Nous, which will be analysed below and paralleled with a similar triad in Origen) as a development of Plotinus' second hypostasis (Nous). Proclus was also aware of the parallel Neoplatonic Triad Being-Power-Activity (ousia, dynamis, energeia), which was also found in Christian Platonists such as Gregory of Nyssa, who was in turn impacted by both Origen and Iamblichus. The latter indeed introduced this triad into Platonism. ${ }^{1}$

The general hierarchy that Proclus indicates in the Elements of Theology 20 is the same as Plotinus': One, Intellect, Soul, and body. Within this arrangement, every order begins with a monad ( $\mu$ ovás) and continues with the multiplicity:

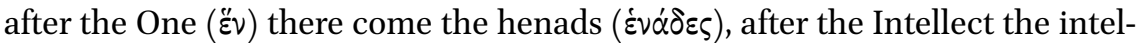
lects, after the Soul souls, and after Nature a plurality of natures (Elements of

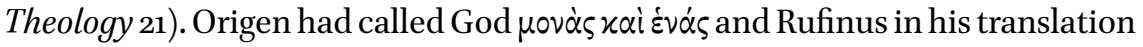

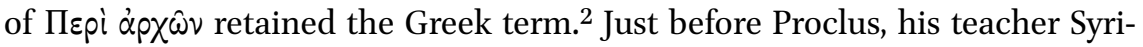

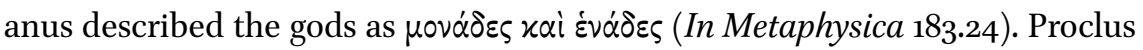
ascribes to someone "venerable to us", that is, again, Syrianus, the doctrine that

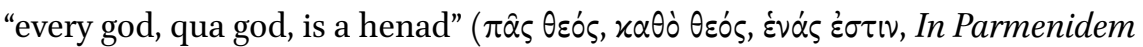
1066.16). Like Iamblichus, and like Origen, Proclus describes God as $\alpha \pi \lambda \omega \varsigma$ हैv, "absolutely and simply One", and $\dot{\alpha} \pi \lambda \circ \hat{v} v$, "simple" (Elements of Theology 127 ; cf. also 1, 6 and 26), as well as timeless and strictly eternal. Proclus, unlike Origen, is

1 As I argued in Ramelli forthcoming - a. On Proclus' thought see, e.g. Chlup 2012.

2 Discussion in Ramelli 2012a. 
no Christian or Jewish monotheist, but a henotheist or polylatric monotheist, ${ }^{3}$ so he does not postulate a single henad, but many henads, which are gods (Ele-

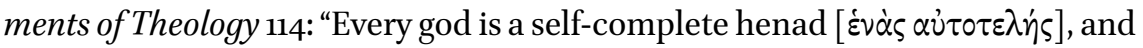
every self-complete henad is a god"). Origen depicted God both as the supreme

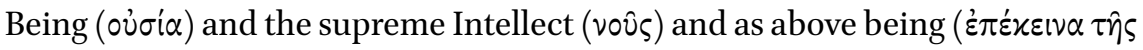

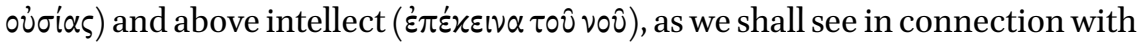
Proclus' criticism of his protology. Proclus in the Elements of Theology 115 states

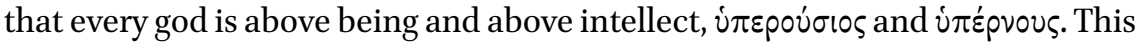
explains his protological criticism of Origen, analysed below.

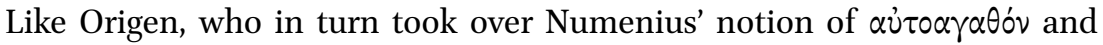
Plato's Good as supreme principle, ${ }^{4}$ Proclus in his Elements of Theology identifies the divinity with the first Good, which is not good by participation, but per se, and all that is good participates in it. "All that in any way participates in the Good is subordinate to the primal Good [ $\tau \dot{0} \pi \rho \omega$ ' $\tau \omega \varsigma \dot{\alpha} \gamma \alpha \theta \dot{o} v$ ], which is nothing

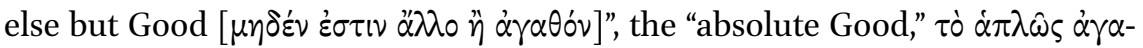

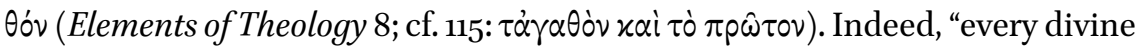

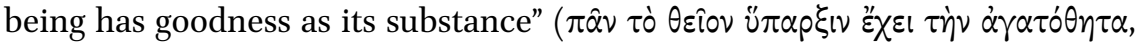
Elements of Theology 121). Against all metaphysical dualism, Proclus embraces a rigorous monism, positing one single $\dot{\alpha} p x \dot{y}$ or $\alpha i \tau i \alpha$ of all and identifying it with the Good and the One (Elements of Theology 11-13). The identification of the One with the Good seems to have been part and parcel of Plato's unwritten

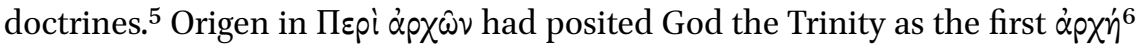
and had identified it with the supreme Good and the One (the Father simply One, the Son "all as One"). ${ }^{7}$

Proclus maintains, like Origen, that the first principle or $\alpha p x \eta \dot{y}$ is creative

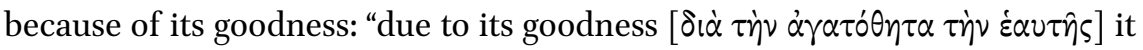

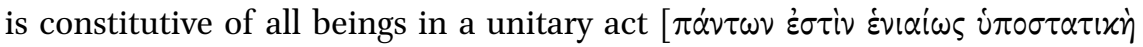

3 Instead of polytheism here, I speak of 'henotheism' (or 'polylatric monotheism', a definition coined by Rainer Hirsch-Luipold for Plutarch, esp. On Isis and Osiris $377 \mathrm{E}-378 \mathrm{~A}$ ) within 'paganism', especially philosophy. See Frede 1999 and the whole book; Edwards 2004; HirschLuipold 2009, with my review in Ramelli 2011a; Ramelli 2014a; Mitchell, van Nuffelen 2010; Pouderon, Usacheva 2017, especially Anders Jacobsen's contribution, who calls 'pagan' henotheism 'inclusive monotheism', and Ramelli 2018a. For the competition between 'polytheism' and 'monotheism' in late antiquity see North 2017. See Rüpke 2018.

4 See Ramelli 2009a; and a further work in preparation.

5 So, at least, according to Aristoxenus (Harmonica Elementa, p. $30=327 \mathrm{~A}$ ) and Aristotle, who, however, does not mention Plato but attributes this doctrine to "some": "Some maintain that

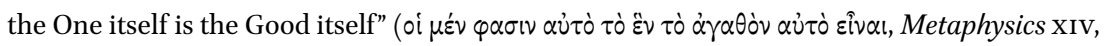
4, 1091b 13).

6 Ramelli 20oga and further in Ramelli, "Hypostasis" (2012).

7 Examined in Ramelli forthcoming-b. 
$\tau \hat{\omega} \nu$ o $v \tau \omega \nu]$ " (Elements of Theology 25). The productive principle in the divine is

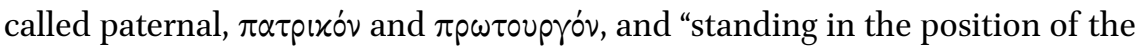
Good" (Elements of Theology 151). For Origen the Father, productive àpX' Good, and the Son is the image of this goodness. Origen, and all the pro-Nicene and anti-"Arian", distinguished between the eternal generation of the Son from the Father and the creation of the world by God (when the Forms-Ideas-Logoi in the eternal mind of God, who is Christ-Logos-Wisdom, became substances at a certain point) ${ }^{8}$

It is remarkable that a distinction between generation as a Father and creation, in respect to God, is drawn by Proclus in the Elements of Theology 157: "It is the function of every paternal cause [ $\pi \alpha \tau$ pixò $\alpha i \tau i o v]$ to bestow the being [Eival] on all things and originate the existence of all beings, whereas it is the

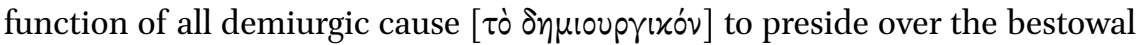

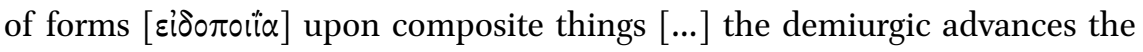
creative office into plurality, while the other, without departing from unity, orig-

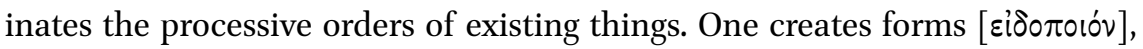

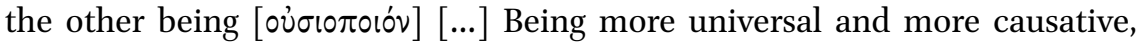

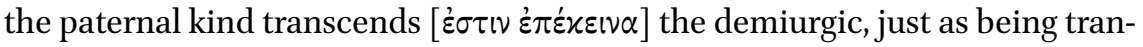
scends form." Origen called the paternal cause God the Father, and the demiurgic cause Christ-Logos-Wisdom, the former the originator of all beings and the latter the creator through the Forms qua Mind of God. For Origen and Christian "Nicene" theologians, too, the intra-Trinitarian process of generation is prior to the extra-Trinitarian creation, being actually eternal; indeed the former per-

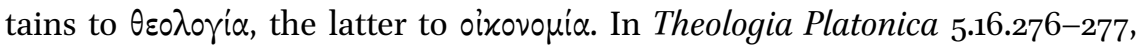
Proclus observes that the paternal cause produces "by its very being" ( $\alpha \dot{\tau} \tau \hat{\omega} \tau \hat{\omega}$ Eival), whereas the demiurgic cause produces "by operating", "by its activity" ( $\tau \hat{\omega} \hat{\varepsilon} \varepsilon \varepsilon p \gamma \varepsilon \hat{v})$. This is the same distinction as Origen and the Nicene Christians posited between God as Father and God as Creator. Origen however maintained that God created everything out of nothing, so that the act of creation was not only a bestowal of forms upon a preexistent matter, but a creation of matter itself, and this not out of God-being not a generation, as in the case of the Son-but out of nothing. ${ }^{9}$

The Forms or Ideas were postulated by Proclus, as already by Origen, ${ }^{10}$ together with the originally Stoic seminal logoi, conceived as intermediaries between the Forms and the world (In Parmenidem 908.36: "It would be absurd

$8 \quad$ Origen De principiis 1.4.5; cf. Commentary on John 1.22.

$9 \quad$ Argument in Ramelli 2018b.

10 This point is examined in a work on Origen, in preparation, which will also point out parallels in Plotinus. 
if the logoi had creative force, while the intelligible Forms were deprived of

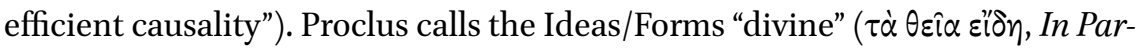
menidem 841.26), as Origen and some so-called Middle Platonists did, who regarded them as abiding in the Mind of God. Proclus too, indeed, makes the Intellect or divine Mind a "plurality of Forms / Ideai" in the Elements of Theology 177 ( $\pi \lambda \eta \dot{\eta} \rho \omega \mu \alpha \varepsilon i \delta \hat{\omega} v)$. Precisely because they are divine-or, with Origen, they are the intelligible world inside God's Logos-Wisdom - they are both

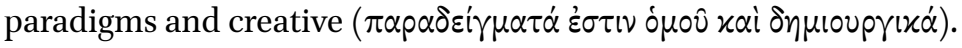

The concern voiced by Proclus in the Elements of Theology 26-27, that the productive principle remains undiminished and unchanged ${ }^{11}$ by the produc-

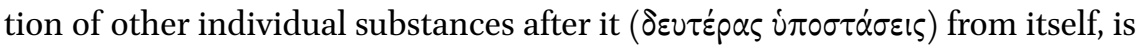
the same as Origen's with regard to the generation of the Son from the Father, who, as he was keen to observe, remained undiminished and unchanged.12 What is more, the very terminology of the product (in Proclus) and the Son (in Origen) as i $\pi \delta \sigma \tau \alpha \sigma \zeta$ is the same. Origen was the main responsible for the meaning of $\dot{\pi} \sigma \dot{\sigma} \tau \alpha \sigma \iota \varsigma$ as "individual substance."13 Origen also stated that the Son is the likeness of the Father, and this is also why he is eternal: xai o $\mu_{0}$ ó-

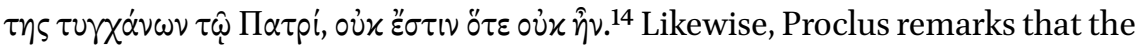
product of the procession is a hypostasis that has a likeness to the principle

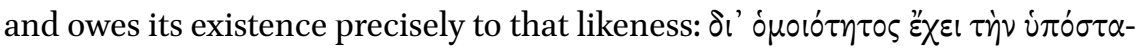
olv (Elements of Theology 29). The culmination of the assimilation to God will be, according to Origen, in apokatastasis, with the eventual deification or $\theta \varepsilon \dot{\varepsilon} \omega$ $\sigma i \varsigma$. This, however, does not mean a confusion between God and creatures and an overcoming of God's transcendence. ${ }^{15}$ The same distinction is drawn and kept by Proclus: "One is the perfection of the gods and another that of beings

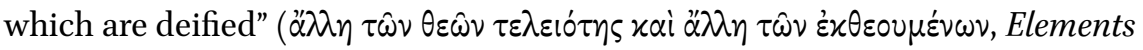
of Theology 153). This is the background against which to view the Noetic Triad in Proclus' Elements of Theology.

Concerning the Noetic Triad in Proclus, Christoph Helmig and Carlos Steel write:

On the whole, Proclus' doctrine of first principles is a further development of Plotinus' innovative interpretation of Platonic philosophy. With Plotinus, Proclus recognizes three fundamental levels of reality called

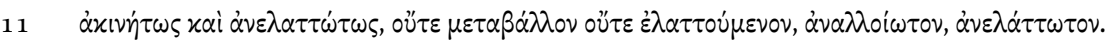

12 Origen's concern was then taken over by Eusebius in relation to Nicaea. See Ramelli $2011 b$.

13 As argued in Ramelli 2012a.

14 Apud Athanasius, De decretis Nicenae synodi 27.1-2, commented on in Ramelli 2o11b.

15 As argued in Ramelli 2013a.
} 
'hypostases' (or self-subsistent entities): One, Intellect, and Soul. However, following a concern of his predecessor Iamblichus for greater precision in the relationship and distinction between the One and Intellect, Proclus distinguishes between the intelligible Being (to noêton - what is the object of intellectual intuition) and the intellective (to noeron - what is intelligizing), and introduces between both, as an intermediary level, the noêton-noeron (what is being intelligized and intelligizing). These three ontological levels thus correspond to the triad of Being, Life, and Intellect, which already play an important role in Plotinus' and Porphyry's speculations about the procession or 'emanation' of the intelligible world from the One, without, however, being hypostasized. ${ }^{16}$

Proclus developed Plotinus' Triad with a new Triad (the Noetic one) in between, likely under the influence of Chaldaean Triads ${ }^{17}$ and especially of Porphyry, who already spoke of a Noetic Triad: "shall we say, following Porphyry, that the one first principle of all beings is the Father of the noetic triad?" ( $\tau \dot{\eta} \nu \mu i \alpha \nu \tau \hat{\omega} \nu$

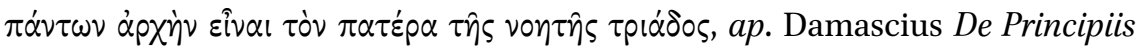
$43=$ Porphyry F367 Smith). ${ }^{18}$ This view was reported, although anonymously, already by Proclus himself, who was very well aware of Porphyry's doctrine and actually had recourse to it: "to posit the primal god as the apex of the noetic world, as I see that some leading authorities on things divine have done, and to posit the Father of that realm the same as the first principle of all beings [...] he is called the noetic Father and the apex of the noetic world, and although he is the principle of coherence for the whole noetic world, he is so qua Father" (In Parmenidem 1070.15-20). Porphyry was in turn probably influenced by Origen in his notion of the Triad..$^{19}$ That Proclus also was familiar with Origen's protological and metaphysical (and perhaps also anthropological) ideas is something that I suspect on the basis of many elements, some of which will be pointed out in this essay.

On the basis of his taking over and expansion of Plotinus' Triad, Proclus even criticized Origen, the fellow-disciple of Plotinus at the school of Ammonius Saccas, for failing to posit the One as the very first principle and stopping instead at the level of the Nous. Proclus mentions an 'Origen' who can be the Christian philosopher not only in the Commentary on the Timaeus, but also in

16 Helmig, Steel 2015 .

17 Proclus, following Porphyry and Iamblichus, wrote a substantial Commentary on these Oracles (Marinus, Vita Procli 26). Majercik 1992; Majercik 2001.

18 See Smith 1992, esp. p. 736-741.

19 As argued by Ramelli 2012a. 
Theologia Platonica 2.4, a refutation ( $\dot{\alpha} \pi \dot{\alpha} v \tau \eta \sigma \iota)$ of the philosophers who failed to consider the One as the First Principle. Here, Proclus' criticism of Origen's protology corresponds to the Christian's protology. Theologia Platonica 2.4 wonders why Origen, who "received the same philosophical formation as Plotinus' from Ammonius, identified as supreme principle, not the One, like Plotinus, but "Nous ${ }^{20}$ and first Being," rather "stopping" here and "omitting the One, which transcends every nous and every being." Origen "deemed Nous the highest principle, identifying it as prime Being and prime One: with this we could not agree, nor would Plato have accepted this doctrine, which has nothing of Plato's philosophy, but is full of Peripatetic innovations." For Plotinus, instead, the One transcended Nous and Being (Enneads 5.1.8; 5.5.6; 5.6.6, according to

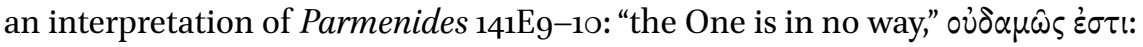
the Parmenides likewise exerted a strong influence on Origen too). ${ }^{21}$ This line was followed by Proclus and radicalised by Damascius. ${ }^{22}$

This is Proclus' full text in Theologia Platonica 2.4:

Thus, I think that the foregoing has made it very clear that the One is the First Principle of all, and the First Cause, and all the others are inferior to the One. I personally wonder at all these exegetes of Plato, who have placed the intellective cosmos among beings, but have failed to reveal the unspeakable transcendence of the One and its existence, which transcends the whole universe, and especially at Origen, who received the

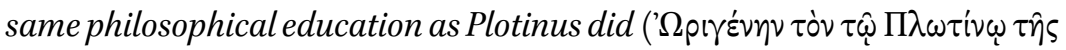

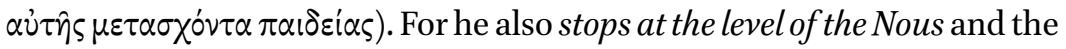

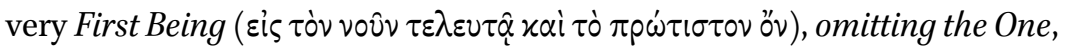

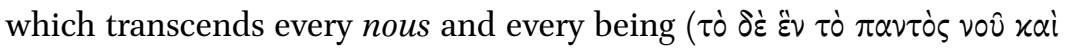

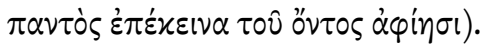

If this is in the sense that the One 'is greater than all knowledge, all definition, and all intuition,'23 then we would not declare him to go far from agreement with Plato or with reality. But if it is in the sense that the One is completely inexistent and non-subsistent, ${ }^{24}$ and the Nous is what the

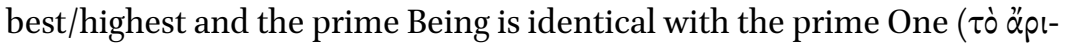

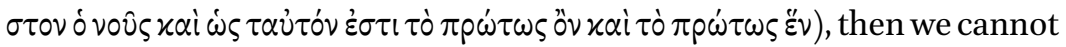
concur with him in this regard, and Plato himself would neither approve

\footnotetext{
20 This was the seat of Ideas / Forms still for Proclus; see Tempelis, Terezis 2017.

21 Argument in Ramelli 2019a.

22 d'Hoine, Martijn 2017; Napoli 2008, with Ramelli 2013 b.

23 Cf. Plato, Parmenides, $142 \mathrm{~A} 1-8$.

24 Cf. Plato, Parmenides, 141D6-142A1.
} 
of him, nor would he include him among his disciples. Indeed, a teaching of this kind is, in my view, very different from Plato's philosophy but is

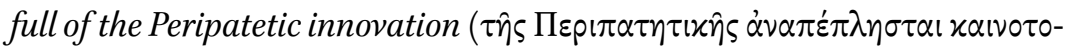
$\mu(\alpha)$ ).

Now, if you wish, let us defend Plato's doctrine briefly, not only against this philosopher, but also against all the others who have supported the same theory, and let us indicate that Plato posits the very first Cause beyond the Nous and transcending all beings, according to the interpretation of Plotinus, Porphyry, and all those who followed this philosophical line.

Proclus seems to catch somehow the ambiguity of Origen's position, between the positing of the One with an apophatic drift, or the removal of the One and stopping at the level of Nous and Being ("if it is in the sense that [...] but if it is in the sense that $\left.[\ldots . .]^{\prime \prime}\right)$. However, Proclus leans towards the second solution as his own description of Origen's metaphysics, that which he criticises as far away from Plato's doctrine and rather influenced by Aristotelian ideas. Note that in the last sentence he considers (problematically) Porphyry as holding exactly the same position as Plotinus with regard to protology and metaphysics.

In the Commentary on the Parmenides 1.636-638, Proclus reports that "some" though that Parmenides was about Being and argued that Being is One. This corresponds to Origen's view according to $T P 2.4^{25}$ and the Christian Origen's view (see the next paragraphs). The Parmenides' style is "unadorned [ $\alpha \dot{x} \alpha \lambda \lambda \dot{\omega}$ $\pi\llcorner\sigma \tau \circ \mathrm{v}]$ beauty" according to "an expert in divine matters" (Commentary on the

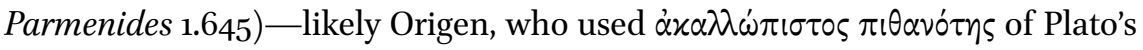
style (Commentary on the Timaeus 1.86.25 ff.). ${ }^{26}$ Proclus ascribes to "leading theologians" the theory that the God of the first hypothesis is "intelligible Father," "the cause of all beings," and a "participated henad" (Commentary on the Parmenides 6.1070). This fits Origen's metaphysics. Proclus objects that the first hypothesis' God is not even a Father.

25 On which Corrigan 200o, p. 153, and Tarrant 2017 agree.

26 In the Commentary on the Parmenides 6.1064.21-1071-8, commenting on the introduction to the first hypothesis (Parmenides ${ }_{137} \mathrm{C}$ ), Proclus discusses the skopos of this hypothesis and disagrees with "some" who regarded "the One in its absolute form" as "without individual substance" $\alpha v 0 \pi$ ó $\tau \alpha \tau o \nu$ (1065). In 7.64.1-16 the same theory is rejected (cf. 1105.32 ff.). The attribution of this doctrine to Origen, however, is unsure. Origen the Christian thinks of the Father-One as a Hypostasis. On the Neoplatonic principle that each Platonic dialogue has a single skopos see Baltzly 2017. This is the same principle applied by Origen to Scripture, whose skopos is Christ-Logos. 
Thus, Proclus attacks Origen for failing to posit a principle superior to Nous. Indeed, Origen identified God the Father with Nous and the Son with Logos, because the Logos reveals the Father just as human logos announces nous' secrets, i.e. what is contemplated by nous (C.Io. $1.277^{-279 ; 282)} \cdot{ }^{27}$ For Proclus, Origen's alleged failure to go beyond Nous depended on Aristotelian innovations. Indeed, the Middle Platonist Maximus of Tyre, who - unlike Origenidentified God with Nous and nothing superior, motivated this with Aristotle's principle that 'the most perfect [ $\dot{v} v \tau \varepsilon \lambda \varepsilon \dot{\sigma} \sigma \alpha \alpha \circ \zeta]$ intellect eternally thinks all at the same time' (Diss. 11.8). Proclus, stating that Origen's protology depended on Aristotelian innovations, may also have thought of Fr.Io.13 - if this is indeed by Origen - which regards God as Nous thinking itself, like Aristotle's divinity: the

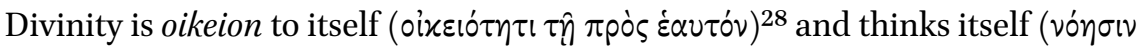

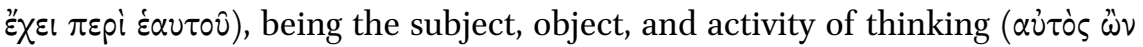

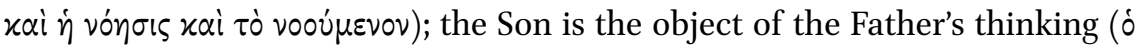

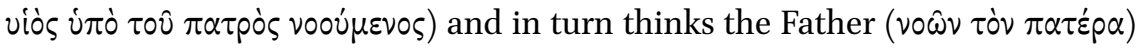

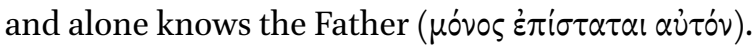

The same line of criticism was kept later by Olympiodorus, who knew Proclus' work very well. Olympiodorus criticised Aristotle for identifying the first principle (theorised in Book $\Lambda$ of Metaphysics) with the Intellect-Nous, the second hypostasis, and not with the One, the first hypostasis (In Alcibiadem 122.13; 145.6-9). This is the same charge that Proclus levelled against Origen, precisely as an "Aristotelian innovation."

Proclus declared that Origen studied at the school of Ammonius, whom Proclus viewed as Aristotelianising qua "harmoniser" of Aristotle with Plato. Origen was acquainted with Peripatetic teachings, ${ }^{29}$ but stuck to Ex 3:14 (LXX), where God self-identifies as Being and on which he commented philosophically in C.Io. 13.21.123. ${ }^{30}$ Proclus, like Celsus and Porphyry-but unlike Numenius and Amelius - would never have acknowledged the importance of Scripture for a Platonist: they deemed it deprived of philosophical content and therefore not fit for being allegorised. ${ }^{31}$

\footnotetext{
27 Irenaeus had identified God with nous and logos: Deus totus mens, totus ratio (Adversus haereses 2.28.4).

28 Origen's appropriation and Christianisation of the Stoic theory of Oikeiosis is argued in Ramelli 2014b.

29 See Ramelli 2014c, received by, e.g., Karamanolis 2016, ch. 23; Chiaradonna 2016, esp. 334335 and 340; Limone 2018; Edwards 2019, 209 and passim; Falcon 2019; Ramelli 2019b.

30 The Johannine theological formula "I am" refers back to Ex 3:14. On this formula see Coutts 2017.

31 See Ramelli 2011c; Ramelli 2018c.
} 
Origen, like Philo (Quod deterius potiori insidiari soleat 16o), identified God with Nous and Being (ovं $\sigma^{\prime} \alpha$ ). Numenius' first God (F11.11-12DP), 'Good Itself' (F16.9-10,14; 20.12DP) and Form of the Good (F2O.4-5,11-12DP), also was Nous

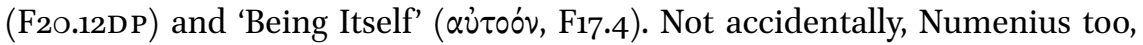
like Origen, was criticised by Proclus. Commenting on Ex 3:14, Origen described God as supreme Good and Being, so as to oppose evil to both and declare evil

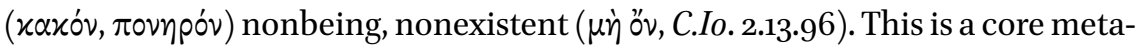
physical pillar of our Origen's, which also bears on his doctrine of apokatastasis. ${ }^{32}$ However, Origen also deemed God superior to Nous and Being (ovं $\sigma^{\prime} \alpha$ ).

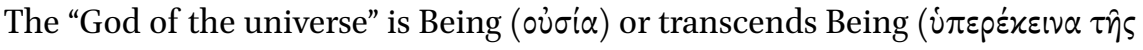

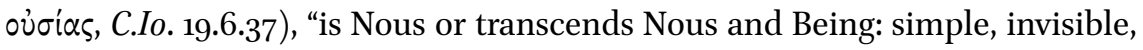

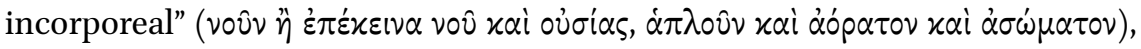
the last point echoing Platonic descriptions of God and Philo's definition of God as $\dot{\alpha} \sigma \omega \dot{\omega} \mu \tau \tau o \varsigma$ o $\sigma^{\prime i} \alpha$ (De opificio mundi 29 ). This is why God can be grasped only by the one who is "in the image of God's Nous" (Contra Celsus 7.38). In Cels. 6.64, Origen quotes Respublica $509 \mathrm{~B}$ on the Good that transcends Being in rank

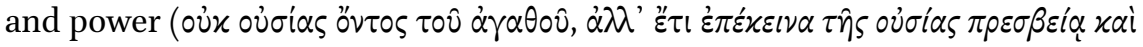

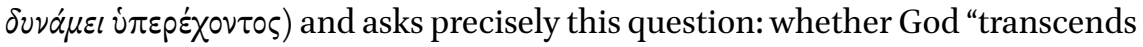

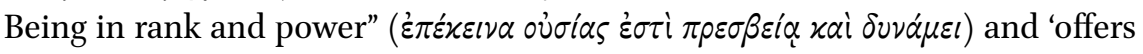

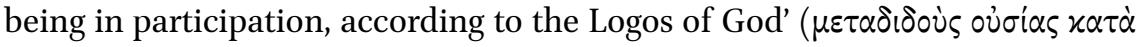

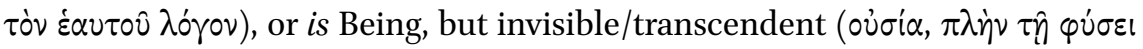
áópatos).

His knowledge of Plotinus' henology may have induced Origen to reflect further on Resp. 509B and to posit God as not only Nous and Ousia, but as transcending both. Plotinus posited the One as above Being and Ousia, while the level of Ousia is that of Nous, whose oneness is not simple, but the result of a multiplicity - as in the case of Christ-Logos-Nous-Wisdom in Origen ${ }^{33}$ so, Being is "complex" or "multiple." ${ }^{34}$ Therefore, the One transcends Being because Being is multiple, in the same way as Nous is multiple, being the seat of all Ideas; moreover, it entails a knower-known divide. ${ }^{35}$ For Origen, God, first

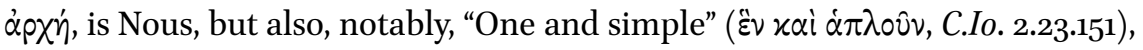
Monad-Henad: "simple intellectual nature (intellectualis natura simplex), from

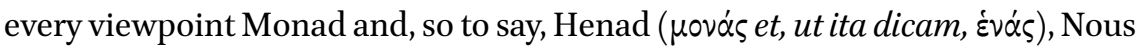
and spring from which comes all intellectual nature ... that simple nature, all Nous" (tota mens, Princ. 1.1.6). Ps.-Justin likewise describes the Pythagorean God

$32 \quad$ Examined in Ramelli 2013a.

33 Argument in Ramelli forthcoming-b.

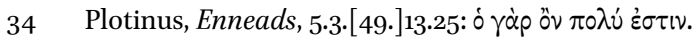

35 On this dichotomy, see Ramelli 2018 d. 


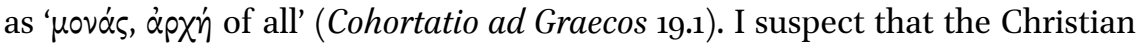
Neoplatonist Victorinus depended on Origen —as often ${ }^{36}$ — when he posited God as Being and above Being (De generatione divini verbi, PL8.1022), and Eusebius was obviously relying on Origen and his apparent ambiguity when describ-

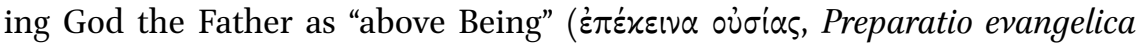
11.21.6) but at the same time also as Nous, although invisible and not manifested

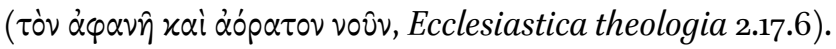

Origen's theory of the Nous and the One was acknowledged later by Ficino as the most authentic form of Neoplatonism. Ficino supported the harmonisation between Neoplatonism (Plotinus and the school of Ammonius) and Christian thought. He seems to have thought that there was only one Origen. In his Compendium of the Timaeus 9, Ficino opposes two Neoplatonic lines of thought: (1) one by Ammonius and Origen his disciple, who identified the One (and Good) and the Nous, exactly as Proclus had indicated, but with the difference that Ficino characterises this as the true philosophical doctrine; (2) the second doctrine, as Ficino recognises, was supported by most Neoplatonists and posited the One above Nous. Ficino will follow it provisionally in his commentary on the Timaeus, but the authentic Neoplatonic doctrine, in his view, is that of Origen, which in turn derived from the teaching of Ammonius Saccas (whom he considered familiar with Christianity: De Christiana religione 35). Now, Ficino overtly supports Origen's doctrine as the true Neoplatonic doctrine.

In light of the observations adduced so far, Proclus is both right and wrong to claim that Origen did not proceed beyond Nous, failing to posit One above Nous. While Clement identified God with Nous and Being, Origen's ambivalence about God as Being and beyond Being reflects Plato's double status of the Good: as Idea-Being, and principle beyond Ideas and Being (Parmenides 142E: "the One neither is one nor is," meaning "nor is Being"). ${ }^{37}$

Thomas Böhm deems Origen's ambivalence between God as Nous and Being and God as transcending Nous and Being as dependent on the first and second hypotheses of the Parmenides. ${ }^{38}$ Plotinus identified the Good of Plato's Repub-

$36 \quad$ As I argued in Ramelli 2013a, p. 6o7-616.

37 On Plato's God as Nous see Menn 1995. Differently, van Riel (van Riel 2013) criticises a metaphysical reading of Plato's divinity as anachronistically Aristotelianising; Plato's gods are not metaphysical principles, but divine souls.

38 Böhm 2002; cf. Böhm 2003, p. 457-459; Böhm 2004, p. 133-139. Contrasting Thomas Böhm (whom he calls "Tobias": 81;90), Edwards 2015, fn. 19 observes: "no Origen is mentioned in the commentary of Proclus on the Parmenides; conversely there is no reference to this dialogue in Contra Celsum, which quotes no fewer than 16 works by Plato." Proclus' Commentary on the Parmenides likely targets Origen in some passages (see above), but does not 
lic with the One of the Parmenides' first hypothesis (Enneads 5.4.1.1-21) — and both Origen and Plotinus knew that Aristotle testified to Plato's identification of the One with the Republic's Idea of the Good. ${ }^{39}$ Princ. 1.1.6 seems also influenced by the first hypothesis (Parmenides ${ }_{137} \mathrm{D}-142 \mathrm{E}$ ) and by Respublica 5 ogb. The description of God as incorporeal also implies the other attributes which Plato refers to the One (Parmenides ${ }_{137} \mathrm{D}-141 \mathrm{~B}$ ): God, incorporeal, is indivisible like the One $(137 \mathrm{D})$, unlimited $(137 \mathrm{E})$, and adiastematic or adimensional (138AB). The relation between God and the Logos in terms of the relation between the sun-rays and the sun's splendour (Princ. 1.1.6a) seems to reflect Plato's relationship between One and Being as one between the sun and its rays (Respublica 516B), so Origen's God would correspond to Plato's One, and God's Logos to Plato's Being. The One of the First Hypothesis participates in nothing, not even in Being (Parmenides 142A); the One of the Seventh Hypothesis is nonbeing, हैv oủx oैv (Parmenides ${ }_{163} \mathrm{E}-174 \mathrm{~B}$ ); God, being Monad-Henad,

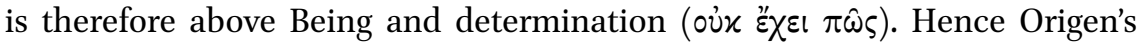
ambivalence between God as Being and Nous, and as transcending both. The latter characterisation Origen found in the 'Gnostic' Basilides, who, perhaps influenced by the Parmenides' Seventh Hypothesis, ${ }^{40}$ described God as "noth-

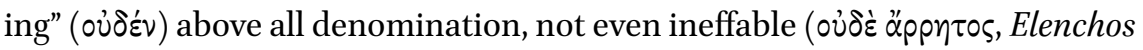
7.20.2-3). The very 'zetetic' structure of the hypotheses of the Parmenides ${ }^{41}$ was taken over by Origen in the 'zetetic' structure of his philosophical theology.

The roots of Origen's ontological ambivalence regarding God are found both in Plato, as just mentioned, and in Scripture. Like Philo, indeed, and unlike Plotinus, Origen could not totally abandon the identification of God with Being,

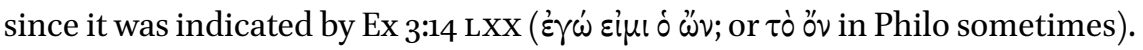
Origen appealed to this verse in many passages throughout his oeuvre, from the Commentary on John and First Principles to the Commentary on Romans. ${ }^{42}$ Especially significant is Princ. 1.3.5-6, which is recapitulated in 1.3.8: Origen argues from Ex 3:14 that all existing beings (omnia omnino quae sunt) participate in God the Father on account of their very existence, since God is Being, while only rational beings (omnes qui rationabiles sunt $=\lambda \circ \gamma\left(x 0^{i}\right.$ ) participate in

name him. Origen does not mention the Parmenides in Contra Celsum, but he relies on it in many ways (as I indicated in "Parmenides in Origen").

Aristotle, Metaphysics, A6.987a-988a; Nicomachean Ethics, 4.1091b; EE A8.1218a.

$40 \quad$ Influence suggested by Hertz 2016.

41 Highlighted by Gardner (Gardner 2018), who rightly speaks of a "gymnastic" and "exercises given to the young Socrates" in the form of the hypotheses.

Fourteen are listed in Biblia Patristica: Origène, p. 6o, and others should be added. 
Christ-Logos, and only the saints or just (sancti) participate in the Holy Spirit (here, Being, Rationality and Holiness constitute one more triad, parallel to the Trinity).

Moreover, by sticking to the identification of God as Being, Origen had the additional advantage of being able to reduce evil to nonbeing, which was one of the major pillars of his doctrine of apokatastasis. The link between Ex 3:14 and the ontological non-subsistence of evil, indeed, is explicit in C.Io. 2.13.96: because God is Being (Ex 3:14) and is Good Itself (Mark 10:8), so that "Good

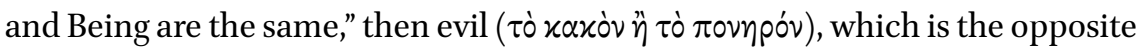

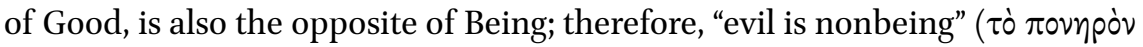

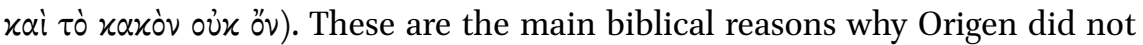
want to give up the identification between God and Being, although, like Plato and Plotinus, he admitted that God is also above Being and Nous and is One (Monad-Henad and simple).

Proclus' criticism of Origen's protology applies not only to Origen's 'Ammonian' treatises, but also to First Principles, Commentary on John, and Against Celsus: if so, he was speaking of the Christian Origen. Besides Böhm, Tzamalikos ${ }^{43}$ also agrees with me that Proclus probably identifies Origen the Christian with Plotinus' fellow disciple at Ammonius', whose metaphysics (and Platonic exegesis) Proclus discusses. In turn, I suspect, Proclus was influenced by Origen, e.g. regarding perpetual first bodies, apokatastasis and its connection to epistrophé, and the tenet $\pi \alpha^{\prime} \nu \tau \alpha \varepsilon^{2} \nu \pi \hat{\alpha} \sigma \alpha^{2} \lambda \lambda^{\prime} \circ i x \varepsilon i \omega \varsigma^{44}$

\section{$2 \quad$ Reversion and Restoration}

Proclus often speaks of restoration or apokatastasis. ${ }^{45}$ The doctrine of $\dot{\alpha} \pi \circ \mathrm{x} \alpha-$ $\tau \dot{\sigma} \sigma \tau \alpha \sigma \iota \varsigma$, restoration or reconstitution, is a remarkable case of a philosophical soteriological doctrine that was elaborated in both "pagan" and Christian philosophy, especially Platonism (also in Stoicism, but with different connotations), not without possible remarkable interactions that still need to be investigated. In Stoicism, this doctrine principally affected the cosmological sphere, and had no soteriological value proper. ${ }^{46}$ The term $\dot{\alpha} \pi 0 x \alpha \tau \dot{\alpha} \sigma \tau \alpha \sigma$ เ (from $\dot{\alpha} \pi \circ \alpha \alpha \theta^{i} \sigma \tau \eta \mu$, "I restore, I reconstitute") is referred by Eusebius to the Stoics' cosmological conception of the cyclical return of the universe to its original

43 Tzamalikos 2016; Ramelli forthcoming- c.

44 See Ramelli 2017a; Ramelli 2015a; On the last point, argument in Ramelli 2020.

45 Examples analysed in Ramelli 2017a.

46 See Ramelli 2013a, Introduction. 
condition at the end of every great year: "The common logos, that is, the common nature, becomes more and more abundant, and in the end dries up everything and resolves everything into itself. It returns to the first logos and the famous 'resurrection' [ $\alpha \nu \alpha \sigma \tau \alpha \sigma \iota \zeta]$ that makes the great year, when the universal restoration [ $\dot{\alpha} \pi \circ \alpha \alpha \tau \dot{\alpha} \sigma \tau \alpha \sigma \iota \zeta]$ takes place." ${ }^{m 7}$ The Stoic use of this term was related to its astronomical meaning, one of the many that this noun bore in antiquity (others were medical, military, political, and so on). It indicated the return of a heavenly body to its initial place after a complete revolution, or the return of all stars to their original place after a whole cosmic cycle. The latter is the meaning on which Stoic cosmology drew. In Stoic cosmology, apokatastasis indicates the periodical repetition of a cosmic cycle, ${ }^{48}$ based on aeons ( $\alpha i \hat{i} \varepsilon \varepsilon \varsigma$ ) or "great years" that return again and again, identical to one another, in an infinite series. The same persons will exist in each aeon, and these will behave in the same ways, making the same choices, forever. This succession is determined by periodical conflagrations ( $\dot{\varepsilon} \kappa \pi v \rho \omega \dot{\sigma} \sigma \varepsilon ı)$ in which all is reduced to fire/aether/logos/pneuma, i.e. Zeus, the supreme, immanent divinity. After

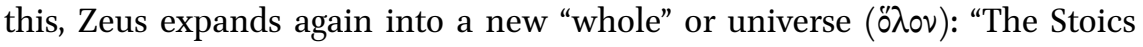

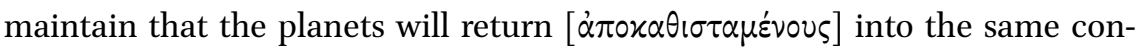
stellation. [...] Universal restoration [ $\dot{\alpha} \pi 0 x \alpha \tau \dot{\alpha} \sigma \tau \alpha \sigma ı \zeta]$ takes place not only once, but many times, or better the same things will continue to be repeated [ $\alpha \pi \circ \alpha \alpha-$ $\theta i \sigma \tau \alpha \sigma \theta \alpha l]$ indefinitely, without end."49

The Stoic doctrine of apokatastasis was mostly rejected by Origen, who wanted to promote his own, Christian doctrine of universal restoration..$^{50}$ The Stoic theory of apokatastasis differs from Origen's Christian doctrine in the following respects: (1) the Stoics postulated an infinite series of aeons, while Origen posited an end of all aeons precisely at the eventual apokatastasis, which will be one and only one, absolutely eternal, and will put an end to every xpóvos and every ai $\dot{\omega} v$. (2) The Stoics thought that in each aeon everything would happen in the same way (or almost) as in all the others, while Origen thought of the aeons as different from one another, in that they are the theatre of the moral and spiritual development of rational creatures. In Cels. 4.12 and 4.6768 , Origen criticises Stoic cosmology, philosophy of history, and apokatastasis in that it denies human free will: "If this is the case, our freedom of will is over. For, if during given cycles, out of necessity, the same things have happened, happen, and will happen ..., it is clear that out of necessity Socrates will always

47 Preparatio evangelica 15.19.1-3 = SVF 2.599.

48 SVF 2.599; 2.625.

$49 \quad S V F 2.625=$ Nemesius, $\mathrm{NH}_{3} 8$.

$5^{\circ} \quad$ E.g. in Cels. 4.12; 4.67-68; 5.2O; Princ. 2.3. See Ramelli 2015 b. 
devote himself to philosophy, and will be accused of introducing new divinities and of corrupting the youths; and that Anitus and Meletus will always be his accusers, and that the Areopagus judges will condemn him to death.... If one accepts this idea, I do not quite know how our freedom will be saved and how praises and blames will possibly be justified" (Cels. 4.67-68). In Cels. 5.20, the Stoic doctrine of cyclical worlds is also ascribed to Platonists and Pythagoreans; in Princ. 2.3.4 the Stoic notion of apokatastasis is again accused of doing away with human free will and responsibility (although the examples do not come from Greek philosophy, as in Contra Celsum, but from Scripture):

If one aeon will be perfectly identical to another, then Adam and Eve will do for the second time the same things that they already did [...]. Judas will betray the Lord again, and Paul will keep again the mantels of those who were stoning Stephen, and all that has happened in this life will happen again. But this theory can be supported by no argument, since the souls are pushed by their free will, and their progresses and regresses depend on the faculty of their will. Indeed, the souls are not induced to do or wish this or that by the circular movement of the heavenly bodies that after many aeons accomplish the same cycle, but wherever the freedom of their inclination has pushed them, there they orient the course of their actions.

Against a cosmology of an infinite series of aeons, in Princ. 2.3.5 the end of all aeons is explicitly affirmed. It will coincide with apokatastasis itself, "when all will be no more in an aeon, but God will be 'all in all." In 3.1 Origen already envisaged "a stage in which there will be no aeon anymore," just as in C.Io.13.3.

In Stoicism, the restoration had no soteriological implications proper, also given the immanentism and materialism of "orthodox" Stoic doctrine: souls are no less material than bodies, and dissolve at the end of each cosmic cycle if not earlier, and then are reconstituted by necessity in the following aeon ( $S V F$ 2.623). In Neoplatonism, both "pagan" and Christian, on the contrary, apokatastasis became the doctrine of the salvation of the soul, with the related crucial question of the universality of this salvation. Will all souls be restored and saved, or not all of them? It is meaningful that some late Neoplatonists ascribed the doctrine of universal restoration and salvation back to Plato, in order to dignify their own theory, but in his eschatological myths Plato did not posit that all souls would be liberated from the torments of Tartarus, as will be seen in the next paragraph. Origen and other Christian Neoplatonists, on the contrary, did support this theory, and their ideas may have been known to "pagan" Neoplatonists who reflected on soteriology. 
I shall not extensively address Porphyry here ${ }^{51}$ but Macrobius, for example, commenting on the myth of Er at the end of Plato's Republic, devoted to the eschatological destiny of such souls, affirms that, according to Plato, all souls will return to their original place, some sooner and others later, but all of them will eventually return. ${ }^{52}$ Even those who have erred most of all, after a very long stay in Tartarus, will return, purified, to their seats. In fact, as anticipated, Plato admitted of exceptions, for souls who are absolutely irrecoverable. According to him, these will remain in Tartarus forever. For he thought that pains were therapeutic and cured the souls, but that some were incurable ( $\dot{\alpha} v i \alpha \tau o$ ) because the crimes they committed were too extreme; therefore, they will never leave Tartarus, where they undergo an eternal punishment. This is stated by Plato oftentimes, and in particular in Phaedrus ${ }_{113} \mathrm{E}$, Gorgias ${ }_{525} \mathrm{C}$, and Respublica 10.615C-616A, although in his Phaedrus the "law of Adrasteia" (248C2) prescribes that, after migrations and purifications, souls return to their original place, after three thousand years for the souls of philosophers, which become winged again at that time, or after ten thousand years for common souls. ${ }^{53}$ This is the only passage, against the others, which might suggest that apokatastasis for Plato was universal. Whereas Plato repeatedly stated that some souls, qua "incurable," would not return to their original place, Macrobius, like his contemporary Gregory of Nyssa, the Christian Neoplatonist and follower of the Christian Platonist Origen, thought that all souls, without exception, would return to their "homeland." ${ }^{54}$ Those who had erred the most will take a very long time to do so, but nevertheless will return. For Macrobius, apokatastasis would really be universal. All souls will be restored to their original seat, because "necesse est omnem animam ad originis suae sedem reuerti." Universal apokatastasis is grounded in an ontological necessity according to Macrobius.

If Macrobius presents Plato as saying something slightly different from what he actually maintained, this means that Macrobius' conviction concerning universal apokatastasis, the return of absolutely all souls to their original state and place, was truly strong. This conviction was equally strong in roughly contem-

$5^{1}$ Analysed more fully in a separate work on 'pagan' apokatastasis. See some preliminary observations in Ramelli forthcoming- d.

In Somn. 2.17.12-14: Saecula infinita dinumerans, quibus nocentium animae, in easdem poenas saepe reuolutae, sero de tartaris permittuntur emergere et ad naturae suae principia, quod est caelum, tandem impetrata purgatione remeare. Necesse est enim omnem animam ad originis suae sedem reuerti, sed quae corpus tamquam peregrinae incolunt cito post corpus uelut ad patriam reuertuntur, quae uero corporum illecebris ut suis sedibus inhaerent, quanto ab illis uiolentius separantur, tanto ad supera serius reuertuntur.

53 On Plato's doctrine of salvation see Menn 2013.

54 See Ramelli 2013 b. 
porary Christian Neoplatonists who supported the doctrine of apokatastasis, such as Gregory of Nyssa or Evagrius, but with the difference that in their view (which is directly based on Origen) this was not simply an ontological necessity, but depended on Christ's incarnation, sacrifice, and resurrection, on human

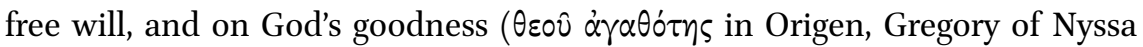
and others; Dei bonitas in the early Augustine). ${ }^{55}$

Macrobius may have had in mind also Porphyry's "universal way for the liberation and salvation of the soul," albeit it is doubtful that Porphyry wanted to find a way for the restoration of all souls, and at any rate he did not find it. According to Augustine De civitate Dei 10.32, Porphyry concluded the first book of his De regressu animae stating that, after examining true philosophy and the doctrines of the Indians and the Chaldaeans, he could not find any philosophy or religion that provided a "universal way" for the liberation of the soul:

Haec est religio (i.e. Christianity), quae universalem continet viam animae liberandae [...] Cum autem dicit Porphyrius in primo iuxta finem de regressu animae libro nondum receptum in unam quandam sectam quod universalem contineat viam animae liberandae, vel a philosophia verissima aliqua vel ab Indorum moribus ac disciplina aut inductione Chaldaeorum aut alia qualibet via, nondumque in suam notitiam eandem viam historiali cognitione perlatam, procul dubio confitetur esse aliquam, sed nondum in suam venisse notitiam.

Victorinus, among the Neoplatonic texts he translated into Latin, also translated Porphyry's De regressu animae, ${ }^{56}$ making it available to Augustine, who devoted almost one book, the tenth, of De civitate Dei to Porphyry. According to Smith, ${ }^{57}$ there are three possible interpretations of the via universalis animae liberandae allegedly sought by Porphyry, as is clear from other passages in De civitate Dei 10.32: (1) either a way for the liberation of all souls (qua universae animae liberantur ac per hoc sine illa nulla anima liberatur), (2) or a way for all peoples (universis gentibus communis), (3) or again a way for the liberation of the whole human being (totum hominem), or at least for the whole of the soul, both the higher and the lower. Smith thought that Porphyry wished to find a way for the liberation of the higher soul of all human beings, but found that only some people can pursue philosophy, which liberates the higher soul (De

55 As I have argued in Ramelli 2013c. Further work on Origen in Augustine is needed and planned.

$5^{6}$ And possibly also his Letter to Anebo at least according to Saffrey 2012, lxiii.

57 Smith 1974, p. 136-141. 
abstinentia 1.27-28); Brahmans and Samaneans in India are restricted groups (ibid. 4.17), and Chaldean theurgy only purifies the lower soul (De civitate Dei 10.9)..$^{58}$ Pierre Hadot ${ }^{59}$ thought that Porphyry did not envisage a universal way, because he knew that Platonism was for an élite, and that some non-Greek religious techniques were very limited. Likewise, according to Gillian Clark, ${ }^{60}$ that Porphyry was in search of such a universal way for the deliverance of the soul is a notion that is conveyed by Augustine's paraphrase of his De regressu animae; the concern for universalism is Augustine's own addition to Porphyry. ${ }^{61}$ It is Augustine who opposes Christianity as a religion who instructs everybody ("as though in a lecture room open to both sexes and all ages and ranks", Epistola 138.10$)^{62}$ to "pagan" philosophy, which was reserved for few people, while "pagan" religion did not teach moral behaviour to anyone (De civitate Dei 2.6; 2.26). According to Clark, therefore, Porphyry was uninterested in finding a universal way for the liberation and salvation of all souls.

Actually, as Augustine himself reports in De civitate Dei 10.29, in his De regressu animae Porphyry repeatedly taught that "every body must be avoided, that the soul may remain with God in blessedness" (omne corpus esse fugiendum ut anima possit beata permanere cum Deo). This can be achieved only by an élite of philosophers and ascetics. According to Augustine, Porphyry is "a Platonist who shows how close Platonism is to Christianity": this is why he is so dangerous. Aaron Johnson is now essentially on the same line as Clark. ${ }^{63}$ Porphyry surely knew Origen's doctrine of universal restoration and salvation, I think, but could not share it because it was Christian: it depended on faith in Christ as God and included also the resurrection of the body. Porphyry's Letter to Anebo-where he took into consideration philosophy, com-

$5^{8}$ Simmons 2006, p. 319-324, thinks that the universalistic theme in Eusebius's work is a reaction to Porphyry (see also Simmons 2009). This is true, but I note there is a strong Origenian basis, and both Porphyry and Eusebius were in dialogue with Origen. Moreover, it is Augustine who presented Christianity, against Porphyry, as the via universalis animae liberandae (De civitate Dei 10.32).

59 Hadot 196o, p. 239.

6o Clark 2007.

61 Clark remarks that "where the relevant text [sc. cited by Augustine] are extant, as they are in the case of Virgil and some of Augustine's other sources (notably Sallust and Apuleius), we can show just how narrowly Augustine selects his material and how forcedly he interprets it to suit his argument [...] it is much more likely that Porphyry denied any claim that there is a single way of liberating the soul" (Clark 2007, p. 130, 136).

62 The late Augustine was convinced that most people will be damned, but in his antiManichaean phase, before his anti-Pelagian phase, he embraced Origen's doctrine of universal restoration, as I argued in Ramelli 2013c and further work.

63 Johnson 2013. 
mon notions, Egyptian religion (esp. Chaeremon) and Chaldean religion (the Chaldean Oracles) — also makes it clear that he did not consider theurgy and religious rituals to be such a way: these may well be universal, but are not ways to the salvation of the soul. Philosophy alone is. This is also why both Eusebius and Augustine, who knew this letter, highly appreciated it for its criticism of "pagan" religion. ${ }^{64}$ The title De regressu animae or The Return of the Soul actually alludes to the restoration or apokatastasis of the soul (not of the whole human being or rational creature, body and soul, as in Origen's and Gregory of Nyssa's thought, where the resurrection of the body is part and parcel of the restoration). ${ }^{65}$ It would be interesting to know what Greek term lies behind regressus; it is possible that Porphyry had $\dot{\alpha} \pi 0 k \alpha \tau \dot{\alpha} \sigma \tau \alpha \sigma \iota \varsigma$, or

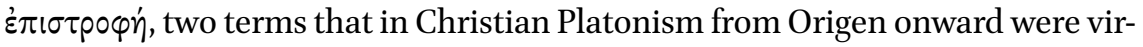
tually synonymic, and will also be closely related in Proclus (see below). I think that Augustine was sensitized by Origen to the issue of universalism, although he could not embrace Origen's Christian doctrine of apokatastasis primarily because its universalism passed through Christ. ${ }^{66}$

In any case, Porphyry did not teach the restoration of all souls, and therefore Macrobius does not seem to have been influenced by him when he maintained that all souls will return to their original condition.

The exact time of composition of Macrobius' works is debated, but it seems to come shortly after two other Latin Christian Neoplatonists who did embrace the doctrine of apokatastasis, Marius Victorinus and Augustine, although the latter did so only during his anti-Manichaean phase, in the $3905 .{ }^{67}$ Origen's theory of universal restoration, which Augustine later rejected mainly for the purpose of his polemic against Pelagianism, was espoused by the "pagan" Neoplatonist Macrobius, whatever the exact relation between Macrobius' apokatastasis doctrine and Origen's may have been. Macrobius might have embraced a Christian doctrine, actually an Origenian doctrine, but he certainly endeavoured to ascribe it back to Plato: obviously he would have felt uneasy about acknowledging any philosophical debt to Christian Platonism. In Christianity, however, the doctrine of apokatastasis, which entailed universal salvation, was soon banned as 'heretical' by the Church of the Empire, in the sixth century,

\footnotetext{
64 Augustine in De civitate Dei 10.11 praises this letter for claiming that whatever demons do (in pagan cult) is an imposture. Indeed, Augustine described Porphyry as "the most illustrious philosopher among the pagans" and "the most learned of the philosophers, though the most bitter enemy of the Christians" in De civitate Dei 22.3 and 19.22.

65 See Ramelli 2013 .

66 Preliminary arguments in Ramelli 2017b; further in Ramelli (forthcoming-c).

67 Demonstration in Ramelli 2013c.
} 
under Justinian. This rejection needs to be studied in depth, but it is significant that Justinian both condemned Origen as a Christian Platonist and wanted to terminate the 'pagan' Neoplatonic school of Athens. These two decisions of his are clearly intertwined.

Proclus too, who lived well before Justinian, seems to have been acquainted to some extent with, if perhaps not directly influenced by, the Christian theory of apokatastasis. Olympiodorus famously classified Proclus, together with his inspirer Iamblichus of Chalcis (who strongly influenced Proclus himself), and Syrianus, among the "religious" exponents of Neoplatonism, as opposed to its "philosophical" exponents such as Plotinus and Porphyry: "Some, such as Plotinus, Porphyry, etc., give priority to philosophy; others, such as Iamblichus, Syrianus, Proclus, and the whole priestly school, give priority to the priestly art."68

Proclus is regarded nowadays as an important inspirer of Dionysius the Ps.Areopagite: some assume that his teacher "Hierotheus" was Proclus; others have supposed that Hierotheus was a disciple of Proclus. Within the usual double reference scheme (to both 'pagan' and Christian Platonism), which Dionysius uses everywhere, it is probable, on the basis of many hints, that both Origen and Proclus lie behind Dionysius' "Hierotheus." ${ }^{69}$ Dionysius indeed, as I have argued, ${ }^{70}$ was also profoundly inspired by Origen. In late antiquity and the Byzantine period, however, Proclus was considered to have been inspired by Dionysius. ${ }^{71}$ The theory of apokatastasis, so prominent in Origen and in Dionysius, dovetailing with that of $\dot{\pi} \pi \sigma \tau \rho \circ \varphi \eta$, is also a major feature of Proclus' thought. Proclus, as I shall show, depicts apokatastasis as ह่ $\pi\llcorner\sigma \tau \circ \circ \varphi$, just like Dionysius. ${ }^{72}$ The latter is closer to Proclus than to Origen in respect to an extraordinary importance attached to liturgy; for Proclus, of course, this is theurgy, for Dionysius, Christian liturgy (but he also called it $\theta$ coupría).

Remarkably, Proclus knew and cited Origen extensively. The Platonist Origen he refers to is probably identifiable with the Christian Platonist Origen, ${ }^{73}$

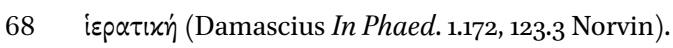

69 Demonstration in Ramelli forthcoming- $g$ and further elements in Ramelli forthcominge and Ramelli forthcoming- $f$.

$70 \quad$ In Ramelli 2013a, chapter on Dionysius.

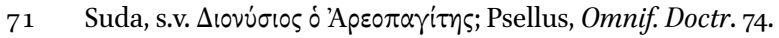

72 For apokatastasis as $\dot{\varepsilon} \pi \iota \tau$ เ atic work is ongoing between 'pagan' philosophical and Christian doctrines of reversal and apokatastasis.

73 The identification is deemed possible or probable by, e.g., Cadiou, Hanson, Crouzel, Kettler, Böhm, Beatrice, DePalma Digeser, Johnson, Markschies, Ramelli, Tzamalikos, Urbano, Marx(-Wolf), Boyarin, Simmons, Tarrant, Haecker, Perczel, Stephen Clark, and others. See, inter alia, Crouzel 1956; Kettler 1979; Böhm 2002; Beatrice 1992, p. 351, and again, on the 
who was, as mentioned, the main theoriser of the Christian doctrine of apokatastasis. In Theologia Platonica 2.4 Proclus observes, as seen above, that he cannot explain the reason why Origen, who received the same philosophical training as Plotinus from Ammonius Saccas (which is indeed the case for Origen the Christian Platonist), ${ }^{74}$ identifies the supreme principle, not as the One, like Plotinus, but as the Nous and the first Being. Origen, according to Proclus, stopped short of theorising the One ("Ev), which transcends Nous, every intellect, and Being itself. Plotinus considered the One to transcend Nous and Being, but Origen regarded Nous as the prime Being and the prime One, and this, in Proclus' view, is not Platonic, but derives from Peripatetic innovations; this is why Proclus cannot agree with Origen. Origen was indeed familiar with Peripatetic ideas, but it is Ex 3:14 that was paramount for his characterisation of God.

The exegesis (mostly allegorical) of Plato's works, and especially of his myths, which Proclus reports in his Commentary on Plato's Timaeus, too, as provided by "Origen" (always cited by Proclus, as by all late antique authors, without further distinctive qualification) are ascribable to Origen the Christian philosopher. When teaching, Origen explained the works of Greek philosophers, among whom Plato had a special prominence. ${ }^{75}$ Likewise, Proclus depicts Origen as interpreting Plato's dialogues. The context of the first relevant passage from Proclus' commentary (1.31) is a debate on the purpose of Plato's Republic. In Proclus' account, Longinus and Origen disagreed on what kind of $\pi \circ \lambda ı \tau \varepsilon \dot{\alpha} \alpha$ Socrates treats in that dialogue. According to Longinus, it was the mid-

basis of the sole Numenius, Beatrice 2009, p. 531: "Origen the Pagan, or the Neoplatonist, has never existed, and the Origen we meet three times in Nemesius' treatise is always the only Christian and Platonist Origen, known to Christian and pagan writers without any distinction"; Beatrice 2019; Ramelli 2009a; Ramelli 2011d; Ramelli 2017c (more arguments in a book in preparation); Markschies (Markschies 2007, p. 3), deems the identification "nicht ganz auszuschließen"; DePalma Digeser 2012, p. 18, 51 and passim; Johnson 2013, p. 153, n. 30, also deems the identification possible; Simmons 2015; Tarrant 2017, p. 324: "it is not certain that they are distinct"; Clark, "Plotinus, Eriugena and the Uncreated Image," lecture in the Oxford Workshop, Eriugena's Christian Platonism and Its Sources in Ancient and Patristic Philosophy: "The Christian theologian Origen may or may not be identical with Plotinus' friend and fellow-pupil, but both Origens (if they are distinct) were students of Ammonius Saccas" (in Ramelli forthcoming- h); P. Tzamalikos rejects "the convenient folly about two Origens (which recently has resulted in two Ammonii!) ... this Origen and the Christian one being the selfsame person" (Tzamalikos 2016, p. 2-4); Marx 2016, p. 4344, deems Origen the Christian and Origen the Neoplatonist the same person. See also Bäbler, Nesselrath 2018.

74 See Ramelli 2ooga.

75 Eusebius, Historia Ecclesiastica 6.17; cf. Gregory-Theodore's Thanksgiving to Origen. 
dle $\pi \circ \lambda ı \varepsilon \varepsilon i \alpha$, since its guardians were soldiers, but according to Origen it was the first $\pi \circ \lambda(\tau \varepsilon i \alpha$, because its guardians were educated in various disciplines, which eventually would come to be regarded as the liberal arts. These $\mu \alpha \theta \dot{\eta} \mu \alpha \tau \alpha$ indeed were important, both in Origen's own formation and in his teaching program. It is natural that he stressed their importance also in Plato's Republic, which could provide a model. What is more, Proclus himself seems to have not only known Origen's position, but also followed it in his own interpretation of Plato's Republic. Here, Proclus does not consider the ideal State delineated by Plato a realistic constitution, but rather a representation of the whole cosmos, where the three classes of citizens symbolise gods, demons, and human beings respectively (In Rempublicam, $1.16 ; 1.47 ; 1.146 ; 2.98 ; 2.325-326$ ). Now, this seems to have been also the interpretation of Origen, as reported by Proclus himself in In Timaeum 1.13. Origen's first $\pi \circ \lambda(\tau \varepsilon i \alpha$ is a notion that fits the cosmic $\pi \circ \lambda i \tau \varepsilon i \alpha$, and Proclus seems to be developing Origen's line. Longinus and Origen, the two protagonists of Proclus' report, knew each other well; Longinus himself, in a passage reported by Porphyry in Vita Plotini 2o, mentions Origen together with Ammonius as a philosopher, a Platonist, of extraordinary intelligence, and adds that he had frequented Origen for a long time. This immediate association with Ammonius is surely due to Origen's being a disciple of Ammonius. Longinus, who was probably born in $212 \mathrm{CE}$, states that he had travelled extensively in his youth for his philosophical studies; he does not say that he frequented Origen's school of philosophy in Alexandria; he may have frequented it in Caesarea, in the advanced 23os. This, from the historical point of view as well, allows for the identification of this Origen - clearly the same as mentioned in Vita Plotini 14, since both passages cite his On Daemons — with the homonymous Christian Platonist.

In In Timaeum 1.76-77, another disagreement between Longinus and Origen is reported. The focus is on the interpretation of Plato's myth of Atlantis in his Timaeus. This dialogue, central to Middle Platonic and later Neoplatonic exegesis, ${ }^{76}$ was very well known to Origen the Christian philosopher, who even read Genesis in its light, as both Philo and Bardaisan had done beforehand. ${ }^{77}$ According to Longinus, this myth is an allegorical expression of the order prevalent in the cosmos, with heavenly bodies such as planets and fixed stars, but according

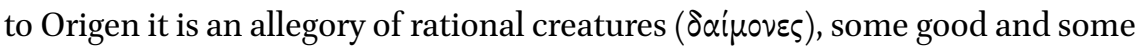
evil. Rational creatures, good and evil, were at the centre of Origen the Chris-

\footnotetext{
$76 \quad$ See Reydams-Schils 2003 .

77 On Philo there is abundant literature; see e.g. Ramelli 2008a and Ramelli 2019c; on Bardaisan qua reader of Genesis in the light of the Timaeus, see Ramelli 2009b and Ramelli 2016a.
} 
tian Platonist's theodicy, protology, philosophy of history, and eschatology. It was obvious for him to read Plato's Atlantis myth on an original, happy state of affairs of a whole population, then suddenly destroyed by a catastrophe, in reference to rational creatures, and especially in reference to their original life, before the fall. These rational creatures or $\lambda$ oүix $\alpha$ are called here by Proclus (according to the meaning of the term in Neoplatonism) $\delta \alpha i \mu о v \varepsilon \varsigma$, just as in the title of one of the two treatises that, according to Porphyry, "Origen" (as Porphyry calls him without further specification) wrote on the basis of Ammonius Saccas' teaching. ${ }^{78}$ Moreover, it was typical of Origen the Christian to allegorise cosmological depictions, such as that of the "upper waters" in Genesis, in reference, not to physical realities, but to rational creatures. For instance, the "upper waters" are the symbol of good rational creatures (angels), while the inferior waters represent evil rational creatures (demons). This style of allegorisation of the cosmological myth of Scripture, typical of Origen the Christian, is the same as that of the interpretation of the cosmological myth of the Timaeus according to Proclus' Origen.

In In Timaeum 1.162, Proclus reports another philosophical discrepancy between Longinus and Origen the Christian. The good condition of body and soul depends, according to Longinus, on earthly physical factors such as a good land and climate, while Origen had it depend on the circular movement of the sky, with an allusion to Respublica 8.546A. Proclus pairs the exegeses of Plato's texts offered by these two prominent disciples of Ammonius Saccas.

Proclus' commentary mentions Origen also in other passages, and his exegesis can again be very well explained in the light of the Christian Origen's deep interest in both allegoresis and philology, as is clearly testified to by his commentaries, Hexapla, and even his homilies. For Origen, allegoresis kept both Scripture's "soul" and its "body," that is, its literal and historical level, without eliminating either of them. ${ }^{79}$ Two mentions of Origen's ideas in Proclus' commentary on the Timaeus perfectly suit Origen's philological, rhetorical, and literary interests. In In Timaeum 1.68 Proclus examines Origen's evaluation of the literary style of Plato's dialogues. Origen argued that such phrases as "Heracles' strength" instead of "Heracles" befit prose, not only poetry. In 1.93 Proclus considers Origen's research into the various meanings of $\dot{\lambda} \lambda \varepsilon \nu \theta \varepsilon \rho \omega \dot{\omega} \tau \alpha \tau o \nu$ in Timaeus 21C. This investigation resembles Origen's close examinations of the meanings of terms in his Scriptural commentaries. Likewise, In Timaeum 1.6o deals with the question of the interpretation of Plato's metaphors. This

78 On the attribution of these woks to Origen the Christian philosopher see Ramelli 2ooga.

79 See Ramelli 2011c; Ramelli 2012b; further in Ramelli 2016b and Ramelli 2018e. 
was especially meaningful for an allegorist such as Origen, who was also very appreciative of Plato's myths, both in their form and in their contents, to the point that he interacted with them and used them in his own elucidation of Scripture. ${ }^{80}$ According to Origen, as Proclus reports, metaphors in Plato's dialogues had cognitive and ethical import; their aim was not to produce pleasure (although Origen admitted that Plato was attentive to stylistic elegance), but to represent passions, i.e. bad emotions, so as to eliminate them. Such an interpretation fits both with Origen's ethics, strongly characterised by the pursuit of apatheia and the criticism of the Epicurean theory of pleasure, and with his appreciation of Plato's myths and of his use of allegory to conceal important truths to those unworthy of knowing them.

In his commentary on the Timaeus 1.83.86, Proclus attests to another exegetical discrepancy, again in connection with the exegesis of Plato's works and his myths. Longinus and Origen, again, are said to have entertained different views concerning Plato's myths. Longinus regarded them as ornamental or psychagogical, but Origen as endowed with gnoseological value and not aimed at producing pleasure - the same motif as in In Timaeum 1.6o. This fits Origen's ethics and his allegorical attitude. Moreover, Proclus remarks in 1.83 that Origen was close to Numenius in his exegesis, in which he refused to see pleasure as the aim of Plato's myths. Numenius, a Middle-Platonist and Neo-Pythagorean, was one of Origen's favourite readings, and also an allegorical interpreter of both Plato and the Bible, like Origen. ${ }^{81}$ Although he does not seem to have been either a Christian or a Jew, he allegorised parts of the Old and New Testament, as Origen testifies, and as Amelius did with the Prologue of John. Numenius was also one of the favourite readings of Plotinus, to the point that the latter was even accused of plagiarising Numenius and had to be defended by Amelius.

In his commentary on the Timaeus 1.63-64, Proclus speaks again of Origen as an allegorical exegete of Plato, within an account of Origen's interpretation of Timaeus 19DE based on Porphyry. Porphyry in turn knew Origen and may have received this anecdote from Plotinus, Longinus, or someone from their circle. The issue at stake was whether Plato included Homer among the ancient poets; Origen pained for three days while dealing with this issue. The description of Origen's hard labour in terms of sweating, within a long mental and even physical effort, perfectly fits the image of Origen the Christian philosopher as an exceptionally hard worker, which earned him the title of

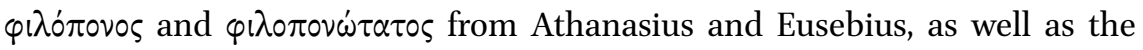

8o Argument in Ramelli 2011c.

81 Analysis in Ramelli 2009a. 
byname Adamantius, which Origen himself may have elected, ${ }^{82}$ and was used by his Christian followers. "Adamantius" was explained by Photius as a reference to Origen's philosophical strength: "They say that Origen was also called Adamantius, because whatever arguments he put together seemed interconnected by stainless-steel ( $\alpha \delta \alpha \mu \alpha \nu \tau^{\prime}(v o l)$ ) bonds". ${ }^{33}$ Origen's extraordinary laboriousness and $\pi$ óvos are repeatedly emphasised by Eusebius in his biography of Origen. ${ }^{84}$ Origen himself highlighted his own hard labour, for instance in his first Homily on Psalm 77, 1: "And God knows how much I have laboured [" $\left.\sigma \alpha \varepsilon^{\prime} x \alpha \dot{\alpha} \mu \circ \mu \varepsilon v\right]$, for his sake and thanks to his Grace, examining together both the Hebrew text and the other editions, so as to establish the emendation of errors." 85

Proclus' account of Origen's positive stance towards Homer also corresponds to Origen the Christian's attitude toward this poet, which again suggests that Proclus was referring to Origen the Christian Platonist. ${ }^{86}$ Thus, it is possible, although not certain, to identify the Origen whose protology and metaphysics Proclus criticised and whose exegesis of Plato he reported, often contrasting it with that of Longinus with Origen the Christian Middle-Neoplatonist, the disciple of the "Socrates of Neoplatonism," Ammonius Saccas, along with Plotinus. Both Origen and Plotinus were described by Hierocles of Alexandria as the most prominent disciples of Ammonius, his "most illustrious disciples" ( $\tau \omega \mathrm{v}$

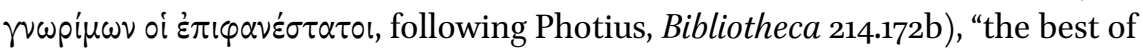

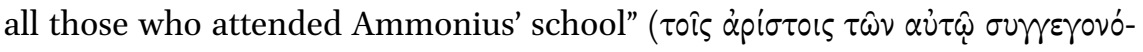
$\tau \omega \nu$, ibid. 251.461b). Hierocles lists Origen immediately after Plotinus ("Plotinus, Origen, Porphyry, Iamblichus and the rest," Photius, Bibliotheca 214.172b) among the most important Neoplatonists, "who agreed with Plato's purified thought" ( $\delta(\alpha \varkappa \varepsilon \kappa \alpha \theta \alpha \rho \mu \varepsilon \dot{\eta} \eta)$, meaning the one purified by Ammonius Saccas.

\section{Restoration and Reversion in Origen and Proclus, and the Noetic Triad}

If Proclus spoke of Origen in a number of passages and this may have been Origen the Christian, in this case Proclus probably knew Origen's doctrine of

\footnotetext{
$82 \quad$ See Ramelli 2ooga.

83 Bibliotheca 118.92b.

84 See the analysis in Ramelli 2011 .

85 Ms München, Bayerische Staatsbibliothek, Gr. 314, fol. $215^{\mathrm{r}}$.

86 Analysis of these other passages in Ramelli 2011d; briefly in Ramelli $2018 \mathrm{f}$.
} 
apokatastasis, just as Porphyry certainly knew it. ${ }^{87}$ An investigation into the terminology of $\dot{\alpha} \pi 0 x \alpha \tau \dot{\alpha} \sigma \tau \alpha \sigma \iota \varsigma$ and $\dot{\alpha} \pi 0 x \alpha \theta i \sigma \tau \eta \mu \iota$ reveals an extraordinary proliferation in Proclus' writings, while the occurrences in earlier "pagan" Platonists are sparse or inexistent: none in Plato, Numenius (although fragmentary), or Plotinus, six in Porphyry, five in Iamblichus, two in Hierocles, but even 145 in Proclus, mostly in his Commentaries on Plato's Timaeus (with the most frequent occurrences: this, significantly, is the same work in which Proclus repeatedly cites Origen's exegesis of Plato) and Republic, ${ }^{88}$ but also in other works such as Theologia Platonica and Elementatio theologica. ${ }^{89}$ This dramatic increase-even taking into account the fragmentary state of works such as those of Numenius and Iamblichus - can hardly be accidental. A scholar has to make sense of this in the light of late antique Platonism, "pagan" and Christian alike.

Proclus reflected a great deal on restoration, and connected this to the return or reversion movement of $\dot{\varepsilon} \pi\llcorner\tau \tau \circ \varphi \varphi \eta$, well aware of the use and function of $\varepsilon \pi / \sigma \tau p \circ \varphi \eta$ in Neoplatonism, 'pagan'90 and Christian alike: in 'pagan' Neoplatonism, down to Proclus and Damascius; and in Christian Neoplatonism, down to Dionysius (in Greek) ${ }^{91}$ and Eriugena (in Latin, but with knowledge of Greek). ${ }^{92}$ Both terminologies, of $\dot{\pi} \pi \sigma \tau \rho \circ \varphi \eta$ and $\dot{\alpha} \pi \circ \kappa \alpha \tau \dot{\alpha} \sigma \tau \alpha \sigma \varsigma$, are interrelated and intertwined, also in later Patristic philosophers, especially in late Platonists, both 'pagan' and Christian Platonists. In their writings-especially in those of Dionysius, but also of Proclus and Damascius, ${ }^{93}$ and later Eriugena$\dot{\alpha} \pi \circ \alpha \alpha \tau \dot{\alpha} \sigma \tau \alpha \sigma \iota \varsigma$ and $\dot{\varepsilon} \pi \iota \tau \tau \rho \circ \varphi \eta$ dovetail, in that $\dot{\varepsilon} \pi \iota \tau \tau_{\rho} \circ \varphi \eta$ is the third movement

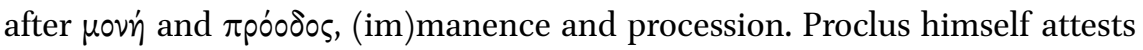

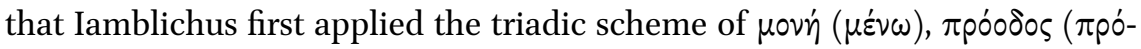

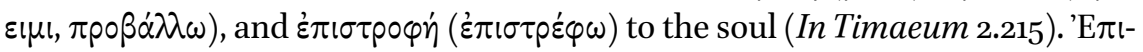
$\sigma \tau р о \varphi \eta$ is the reversion-return-conversion to one's source.

$87 \quad$ See Ramelli 2017 b.

88 On this commentary see now Proclus, Commentary on Plato's Republic, Volume I, 2018.

89 Complete inventory in the work on "pagan" philosophical notions of apokatastasis, in preparation.

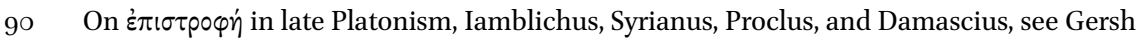

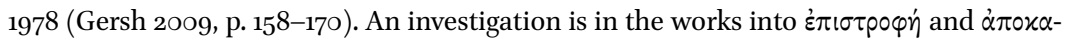
$\tau \dot{\alpha} \sigma \tau \alpha \sigma \iota \varsigma$ in Greek philosophy, including the dovetailing of both notions in late Neoplatonism, both 'pagan' and Christian.

$91 \quad$ As argued in Ramelli forthcoming- $\mathrm{g}$.

92 Ramelli 2013a, chapter on Eriugena.

93 Damascius described the three movements in Dubitationes et Solutiones 1.169.24-27; the

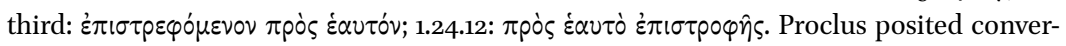
sion/reversal for all spiritual or self-constituted principles (ET 44); Syrianus had described the Forms as 'divine essences, not divided into parts, which revert/are reverted to them-

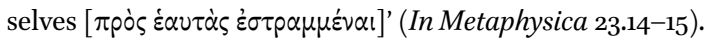


One of the most interesting examples of this dovetailing and sometimes converging terminologies is Dionysius; he probably followed authors he knew, such as Clement, Origen, Gregory Nyssen, Evagrius, and Neoplatonism, from

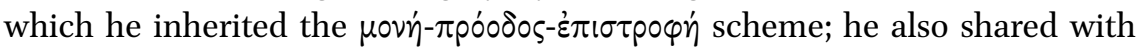
these thinkers the metaphysical tenet of the ontological non-subsistence of evil. ${ }^{94}$ Now, apokatastasis for Dionysius, just as for Eriugena afterwards, coincides with the culmination of $\dot{\pi} \pi \sigma \tau \rho \circ \varphi \eta$, the third movement, the return of all beings to their Cause.

Many are the passages that confirm this, but I single out the following three. In the Divine Names 1.7.596c-597a, Dionysius parallels God's action of bringing all to perfection to God's "converting" activity, i.e. the action of having all crea-

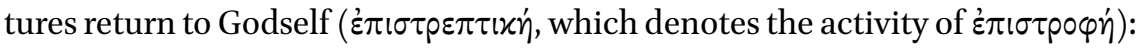
"The Cause of All is 'all in all', according to the Biblical saying, ${ }^{95}$ and certainly it must be praised in that it is the Giver of existence to all, the Originator of all beings, ${ }^{96}$ who brings all to perfection ( $\left.\tau \varepsilon \lambda \varepsilon i \omega \tau i x \eta \dot{)}\right)$, holding them together and protecting them; their seat, ${ }^{97}$ which has them all return to itself [ $\pi$ pò $\varsigma$ żu$\tau \dot{\eta} \nu \varepsilon \dot{\pi} \pi \sigma \tau \rho \varepsilon \tau \tau \kappa \dot{\eta}]$, and this in a unified, irresistible, absolute, and transcendent way."

In Ecclesiastical Hierarchy 82.17 and 83.7, the superimposition of apokatas-

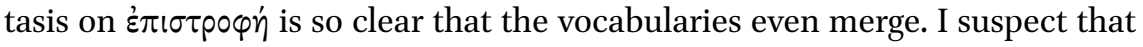
Dionysius merged them consciously. The movement of the priest from the altar to the extremities of the church and then back to the altar is assimilated to the

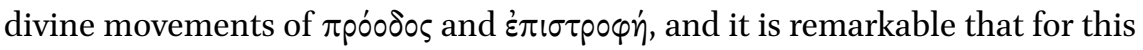
movement of return/reversion/conversion the terminology of apokatastasis is

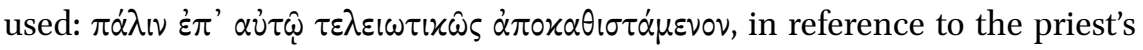

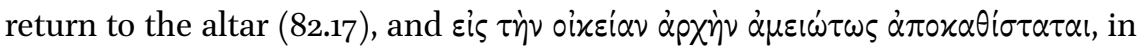
reference to the spiritual interpretation of this return (83.7). Apokatastasis is

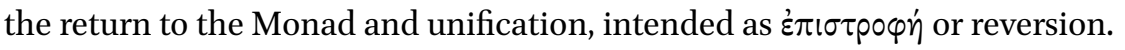

My hypothesis is further confirmed by the Divine Names 4.14 (p. 160.15),

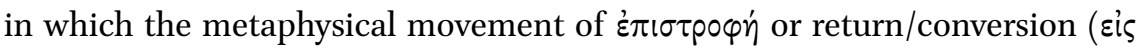

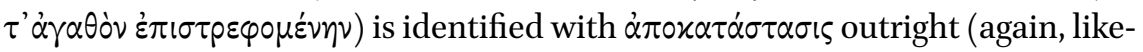
ly deliberately). Indeed, the terminology of apokatastasis is directly employed for the movement of $\dot{\varepsilon} \pi \sigma \tau \rho \circ \varphi \eta$ : God's love forms a circle that proceeds from the Good-for God is "Beauty and Good itself" — and returns to the Good; it

94 See Ramelli 2013a, the chapter on Dionysius.

951 Corinthians 15:28.

96 This denotes the creation, which parallels the moment of $\pi$ póodos or procession.

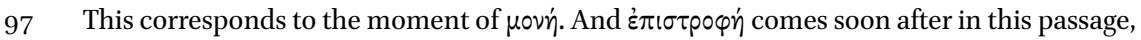
in the adjective $\dot{\pi} \pi$ $\sigma \rho \varepsilon \pi \tau i x \dot{\eta}$. 
"always proceeds, remains, and returns to the same" Good (

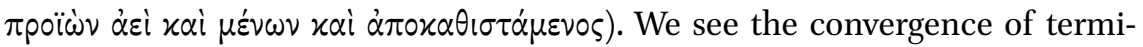
nologies. Now, it is remarkable that in fact Dionysius adapted a proposition coming precisely from Proclus' Elements of Theology (in particular from 146),

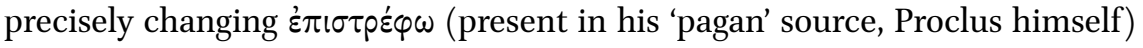
into $\dot{\alpha} \pi \circ x \alpha \theta i \sigma \tau \eta \mu$ i: "Divine love demonstrates in a particularly clear way its lack

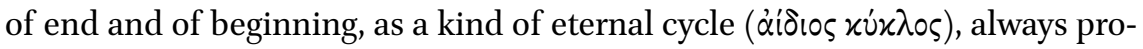

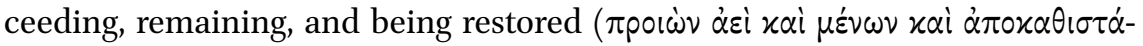
$\mu \varepsilon v 0 \varsigma)$ )" (Divine Names 4.14). Dionysius seems to read Proclus through Origen, whom he knew very well and who may even lie behind the "Hierotheus" and the theologians and hymnologists whom he cites as auctoritates. The influence of Origen's First Principles and commentary on the Song of Songs on Dionysius is notable. ${ }^{98}$ Dionysius appears aware that the doctrine of apokatastasis, and even the dovetailing of $\dot{\pi} \pi \_\tau \rho \circ \varphi \eta$ and apokatastasis, which he applies here, comes from Origen.

Indeed, all this is a doctrine that Dionysius ascribes to his teacher Hierotheus, who developed it in his Hymns on Love, and the inspired exegete that this "Hierotheus" represents is very probably Origen, especially in his commentary on the Song of Songs, as I argued extensively elsewhere (and, due to Dionysius' double reference scheme, Hierotheus may simultaneously refer to Proclus himself): 99

The only one who is Beauty and Good per se is the manifestation, so to say, of itself through itself, the good procession of the transcendent unity, and simple movement of love, self-moving, self-operating, proceeding in the Good and gushing out from the Good to the beings and returning again to the Good or converting to the Good ( $\dot{\pi} \mid \sigma \tau \rho \varepsilon \varphi \circ \mu \varepsilon \dot{\varepsilon} \eta \nu)$. In this the divine love exceptionally clearly shows its own lack of an end and a beginning, like a kind of infinite and absolutely eternal circle through the Good, from the Good, in the Good, and toward the Good, proceeding around in an introversive non-wandering spiral, always proceeding, remaining, and returning / converting in the same movement and the same way. These truths were also explained, in his divinely inspired exegesis, by my illustrious and holy initiator in his Hymns on Love. It will be particularly appropriate to quote from these Hymns and thus provide my own discourse on love with a sacred introduction, as it were: "Love, be it divine or angelic

98 See Ramelli forthcoming- g.

99 See Ramelli forthcoming- e. 
or intellectual or psychic/animal or physical, should be understood as a unitive force that gathers together $[\ldots]$ ".

Now, the lexicon of $\dot{\varepsilon} \pi \sigma \tau p \circ \varphi \eta$ was a terminology already used by Origen, well known to both Dionysius and Proclus, and connected to the doctrine of apokatastasis. Origen's terminology of $\dot{\pi} \iota \sigma \tau \rho \circ \varphi \eta^{\prime}$ is rich and significant, and often dovetails with the notion of apokatastasis or restoration, a key concept in Origen's philosophical theology, history of salvation, and exegesis. In this sense, Origen seems to anticipate the function of $\dot{\varepsilon} \pi(\tau \tau \rho \varphi \varphi \eta$ in later Neoplatonism, 'pagan' and Christian alike, also with respect to the interrelation of

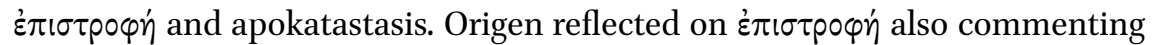
on the uses of $\dot{\pi} \pi \sigma \tau \tau^{\prime} \circ \eta_{\eta}$ in Scripture in light of his philosophical and eschatological reading. He was familiar with both Hebrew and Greek terminologies for

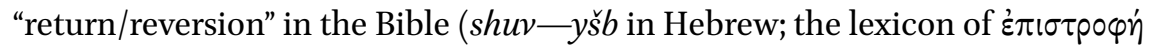
and $\dot{\alpha} \pi \circ x \alpha \tau \dot{\alpha} \sigma \tau \alpha \sigma \iota \zeta$ in the Septuagint and the New Testament). This acquaintance was facilitated by his Hexapla, which aligned both the Hebrew and the Greek versions of Scripture.

Origen used the lexicon of $\dot{\pi} \pi \sigma \tau \rho \circ \varphi \eta$ - conversion in connection not only with Platonism, but also with the occurrences of this lexicon in the Bible. This is one of the many remarkable parallels that he found between Scripture and Plato/Platonism. Psalm 21:28-30 prophesies that "all the families of the peoples" will adore God and "all the boundaries of the earth will (re)turn/convert ( $\left.\dot{\varepsilon} \pi \sigma \tau \rho \alpha \varphi \eta^{\prime} \sigma o v \tau \alpha l\right)$ to the Lord." The agent of this eschatological, universal return to the Lord is God: "for the kingdom belongs to the Lord, and the Lord governs the people" (v. 29). In the Bible, Origen found the connection between

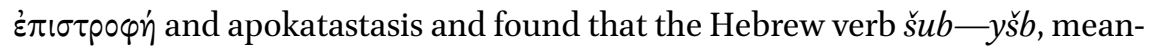
ing the reestablishment of a former relationship or a return, could be rendered by both terminologies in Greek. For instance, in Isa 23:17, yšb is rendered in the Septuagint by $\dot{\alpha} \pi \circ \kappa \alpha \theta i \sigma \tau \eta \mu l:$ God restores Tyre to its ancient prosperity ( $\dot{\alpha} \pi \circ x \alpha-$

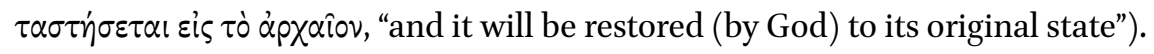
In Hebrew, the verb comes again from $y s ̌ b$. The phrase used here, $\alpha \pi 0 x \alpha \theta i \sigma \tau \eta \mu l$

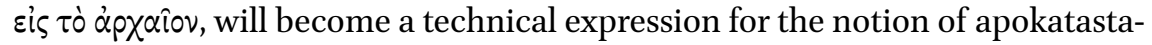
sis in authors such as Origen and Gregory of Nyssa; it highlights their idea that the restoration is a restoration to one's original state. 100

It happens that, within the same passage, the selfsame verb, šub-yšb, is rendered in the Septuagint with both $\alpha \pi \circ \alpha \alpha \theta i \sigma \tau \eta \mu$ ("I restore, I re-establish") 101

100 See Ramelli 2013a, the initial section on Scripture and the chapters on Origen, Nyssen, and others.

101 The verb $\dot{\alpha} \pi \circ \kappa \alpha \theta i \sigma \tau \eta \mu / / \dot{\alpha} \pi \circ \alpha \alpha \theta i \sigma \dot{\alpha} \nu \omega$, which in the LXX almost always translates the 
and $\dot{\varepsilon} \pi\llcorner\tau \tau \dot{\varepsilon} \varphi \omega$ ("I convert, I return"). In Jer 15:19, God who will restore Israel if

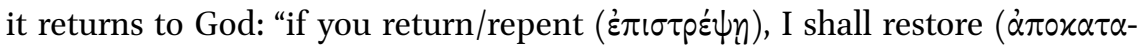
$\sigma \tau \dot{\eta} \sigma \omega)$ you." Origen interpreted this verse, too, as a reference to apokatastasis: God will restore the person who repents/converts. Both verbs in this sentence, however, in Hebrew derive from the same verb, šub-y̌sb.

Elsewhere in Jeremiah, Origen found the verb šub-yšb translated with $\dot{\alpha} \pi 0$ -

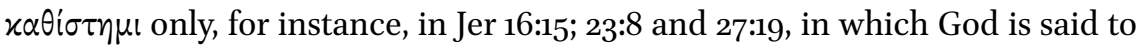
restore Israel in the future. In the first passage, "I shall restore ( $\dot{\alpha} \pi \circ \alpha \alpha \tau \alpha \sigma \tau \dot{j} \sigma \omega)$ them to their land, which I gave to their forefathers," in the Hebrew Vorlage the verb is once more $y \check{s} b$. In the second passage, "The Lord is alive, who gathered the whole offspring of Israel ... and restored ( $\dot{\alpha} \pi \circ \alpha \alpha \tau \varepsilon \tau \tau \eta \sigma \varepsilon)$ them into their land," in Hebrew the verb is again $y s ̌ b$. The third passage, Jer 27:19, reads, "and I shall restore ( $\dot{\alpha} \pi \circ \alpha \alpha \tau \alpha \sigma \tau \dot{\eta} \sigma \omega)$ Israel [...]"

Similarly to what happens in the case of the Hebrew verb šub-yšb, rendered by two verbs in the Greek $\operatorname{Lxx}(\dot{\varepsilon} \pi / \sigma \tau \rho \dot{\varepsilon} \varphi \omega$ and $\dot{\alpha} \pi \circ x \alpha \theta i \sigma \tau \eta \mu)$, in the Latin versions of the Bible, the same verb renders both $\dot{\varepsilon} \pi \mid \sigma \tau \rho \dot{\varepsilon} \varphi \omega$ and $\dot{\alpha} \pi \circ x \alpha \theta i \sigma \tau \eta \mu$. In Jer 15:19, the sense of "conversion" is felt as preponderant, to the point that both

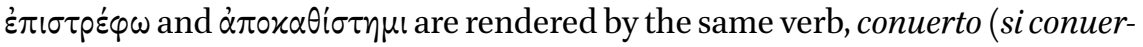
teris, convertam te).

In the New Testament, instead, in the Vulgate, all occurrences of the verb $\alpha \pi \circ \alpha \alpha \theta i \sigma \tau \eta \mu$, both in its therapeutic meaning and in its eschatological sense of restoration, are systematically rendered by restituo, and in Acts 3:21 the corresponding noun, $\dot{\alpha} \pi \circ x \alpha \tau \dot{\alpha} \sigma \tau \alpha \sigma \iota$, , is translated restitutio. Both Latin verbs are used by Rufinus, Jerome, and others to convey the meaning of apokatastasis and that of conversion and return to God. ${ }^{102}$ Both meanings are related, since the former depends on the latter.

Now, for Proclus, the soul is the main protagonist of the return and restoration (as for Philo, Clement, Origen, and followers), but it is by no means alone. The whole cosmos is involved in restoration (an aspect that Gregory of Nyssa also stressed). ${ }^{103}$ In this respect, it must be noted that a good deal of occurrences of the terminology of apokatastasis in Proclus (about one fifth) are related to the astronomical and cosmological meaning of this term, for instance

Hebrew verb $y s ̌ b$ when it does not simply mean "to constitute," but "to reconstitute, to reestablish, to restore," and in the New Testament is widely used, in Greek essentially means "to restore, re-establish, reconstitute."

102 See Ramelli 2013a, the initial section on Scripture, and the chapters on Rufinus, Jerome, Ambrose, Augustine, etc.

103 Ramelli 2013a, the chapter on Gregory. This is an aspect that goes back to Origen, although he was primarily concerned with the apokatastasis of rational creatures. 
(1) the apokatastasis of spheres, planets, or stars ${ }^{104}$ - a number of these in the Hypotyposeis astronomicae ${ }^{105}$ _ or (2) the combination of apokatastaseis that keeps the cosmos in order, ${ }^{106}$ or (3) the definition of the whole of the time as a period of all the universe, which embraces many restorations of the planets. ${ }^{107}$

However, Proclus closely connects to this cosmological apokatastasis also the apokatastasis of souls, so that, for instance, as I shall point out, the apokatastasis of the universe, comprising those of all planets and occupying the

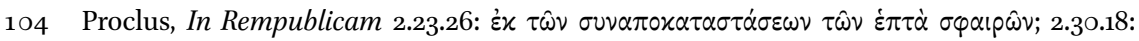

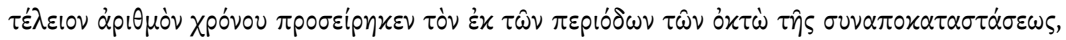

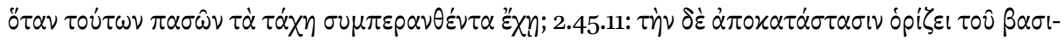

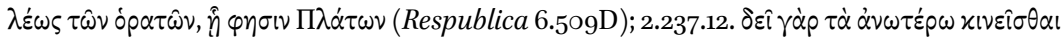

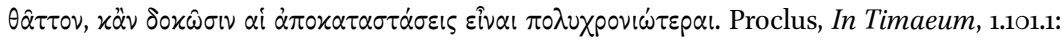

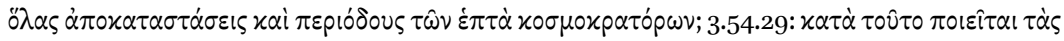

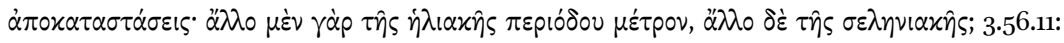

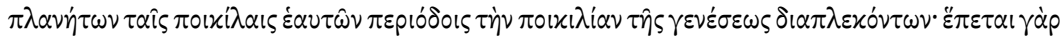

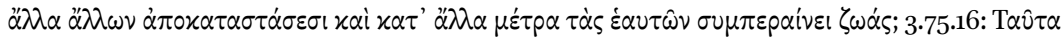

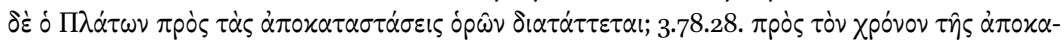

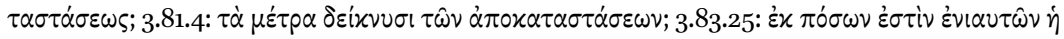

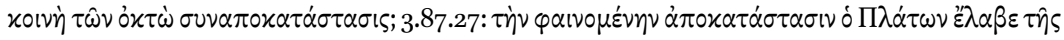

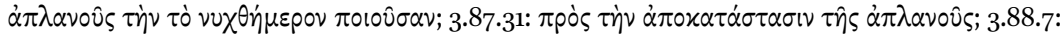

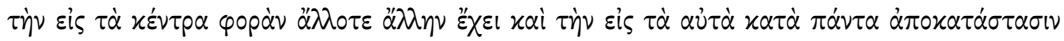

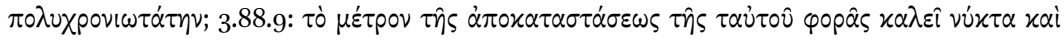

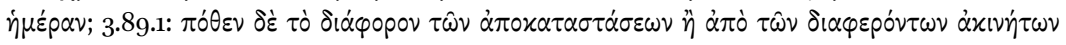

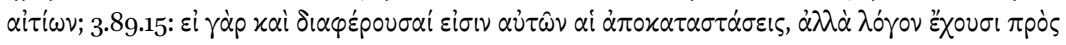

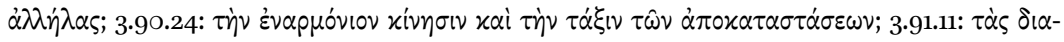

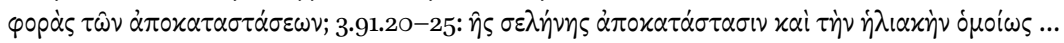

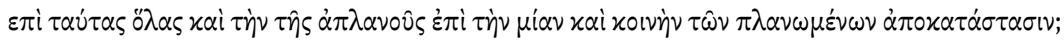

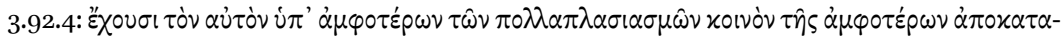

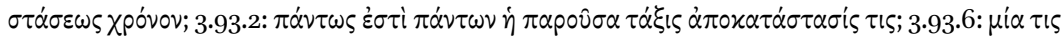

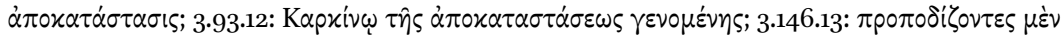

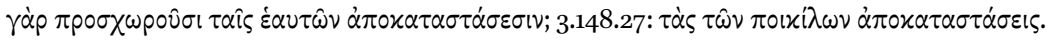

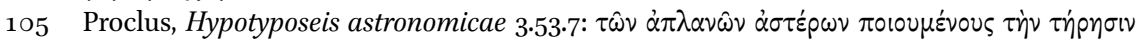

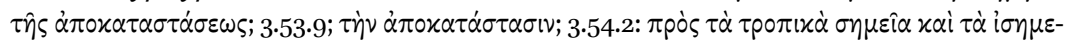

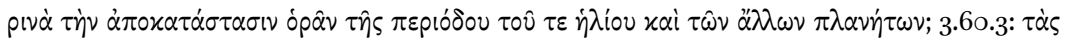

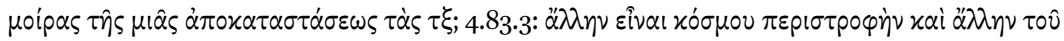

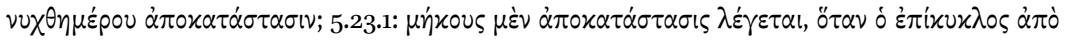

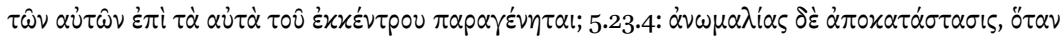

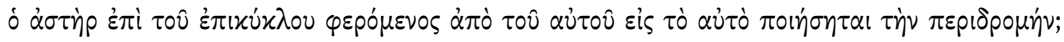

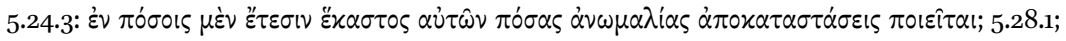

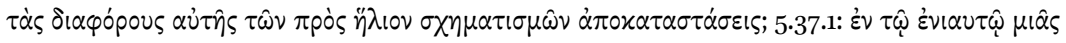

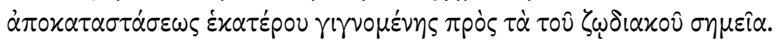

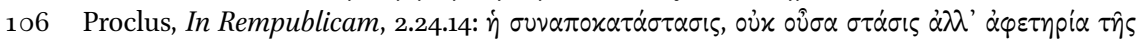

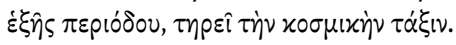

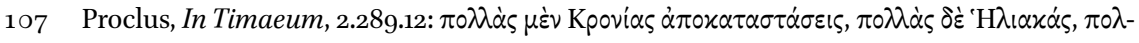

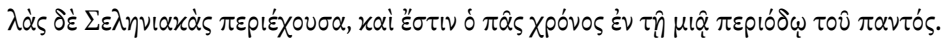


whole time, coincides with the apokatastasis of the world soul, which includes those of all souls and extends to the whole time. Consistently, Proclus draws a parallel between cosmic-astronomical restorations and restorations of souls (In Rempublicam 2.267.28). ${ }^{108}$ Indeed, he is clear in many passages that apokatastasis involves both corporeal and incorporeal realities. ${ }^{109}$ As is evident from

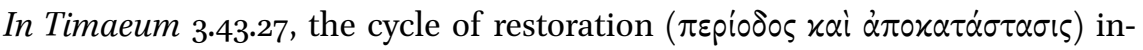
volves not only incorruptible realities ( $\dot{\alpha} \delta \dot{1} \dot{\varphi} \theta$ Op $\alpha$ ), such as souls, but also all realities subject to generation, $\pi \dot{\alpha} \nu \tau \alpha \tau \dot{\alpha} \gamma \varepsilon \nu \eta \tau \dot{\alpha}$.

Plotinus in fact received the doctrine of apokatastasis, but, as I have pointed out, he lacks the terminology of apokatastasis, and developed this theory differently from his fellow disciple Origen. It would be very interesting to know whether their common master, Ammonius Saccas entertained and taught the theory of apokatastasis, as his contemporary Christian Platonists Clement of Alexandria and Bardaisan of Edessa did: and if so, in which form. In the only two loci in which Plotinus refers to this theory, Enneads 4.3.12 5.7.1-3, he seems to adhere to the scheme of infinite apokatastatic cycles, during which the same events occur and the same individuals live, making the same choices, without end. This scheme, in its Stoic form, as I have indicated above, was criticised by Origen.

Plotinus presents his closest approximation to the terminology of apokatas-

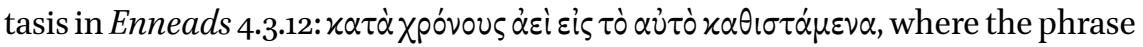

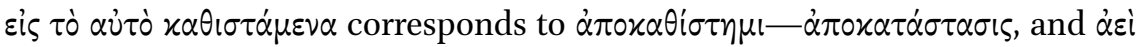
indicates an infinite cyclicality. This periodical reconstitution, Plotinus states, includes the descents and reascents of souls ( $\varkappa \alpha \theta$ ó Enneads 5.7.1-3, Plotinus is reasoning within a framework of infinite cosmic

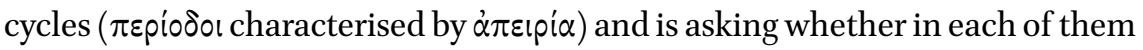
there exist logoi of all the individuals that are generated within a single cosmic cycle. He concludes that "the whole cosmic period includes all logoi and therefore the same things happen again and again according to the same logoi" ( $\dot{\eta}$

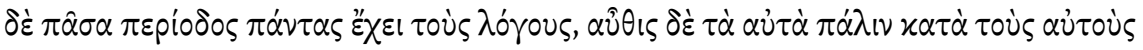
$\lambda$ órous). Plotinus' adhesion to the model that was also maintained by the Stoics is clear in Enneads 4.7.2: "The same, in every detail, repeats itself from period to

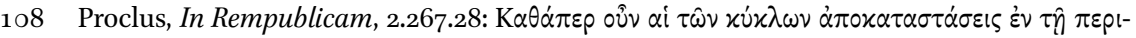

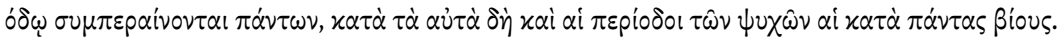
And in In Timaeum 3.19.31 Proclus draws a parallel between the restoration of a human soul and that of heavenly bodies such as the sun and the moon: $\alpha \dot{v} \theta \rho \omega \pi \circ \nu \delta \dot{\varepsilon} \tau 0 \sigma o ́ v \delta \varepsilon, \bar{\eta} \lambda$ 1ov

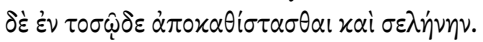

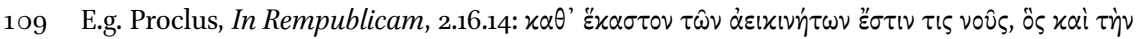

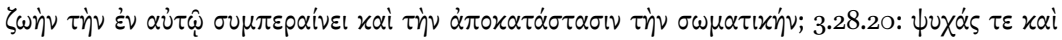

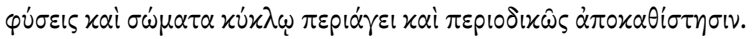




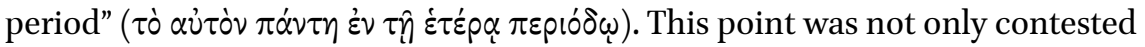
by Origen, as I have pointed out (on the basis of the Biblical notion of the end of the world and centred on a final, definitive apokatastasis), but also dropped by Proclus as well. ${ }^{110}$

Moreover, Proclus is closer to Origen than to Plotinus' line in the Elements of Theology 211, when he rejects Plotinus' (admittedly novel) doctrine of the undescended soul: "Every partial soul, descending into the realm of generation, descends in its entirety $\left({ }^{\prime \prime} \lambda \eta\right)$ : it is not the case that a part of it remains above, and the rest descends." Proclus utters a similar statement in In Parmenidem 948: "We ought not to maintain that a part of the soul remains above ... nor should we point that the soul has the same substance as the gods." Plotinus was aware, and declared, that his doctrine was still extraneous to the Platonic tradition in his time: it was "against the opinion of the others," $\pi \alpha \rho \dot{\alpha} \delta \delta \hat{\xi} \xi \alpha \nu \tau \hat{\omega} \nu \dot{\alpha} \lambda \omega \omega \nu$, meaning of the other Platonists (Enneads 4.8.8). Damascius also will refuse to adhere to the doctrine of the undescended soul (In Parmenidem 2.254.3-10), as Iamblichus and Proclus had already done.

Similarly, Proclus seems closer to Origen than to Plotinus when he rejects

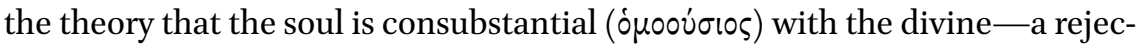
tion already explicitly voiced by Origen against some "Gnostics"111 — and identifiable with the Intellect and even the One. ${ }^{112}$ Iamblichus' concept of the soul as changeable, even in its substance, since it descends entirely, does not fully convince Proclus, although in general Proclus was very much influenced by Iamblichus. According to Proclus, the human soul does descend entirely (against Plotinus), but it does not undergo changes in its substance. ${ }^{113}$ In the Elements of Theology 192, Proclus depicts the soul as amphibious: the soul is an eternal substance, but its activities are accomplished in time. Reflecting on

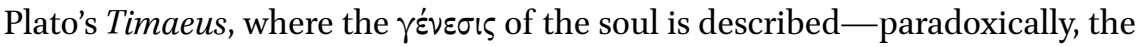

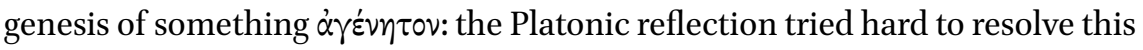
puzzle-Proclus interprets it in the sense that the soul is continually generated, and eternally receives the power to exist. ${ }^{114}$

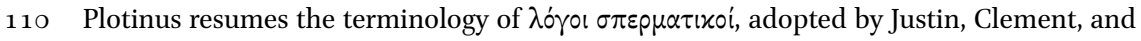
Origen as well, when in Enneads 4.7.3 he claims that "we ought not to fear the infinity of

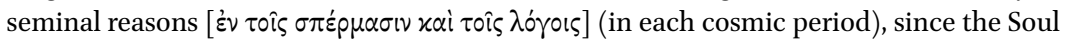
possesses all."

111 See Ramelli 2011b.

112 Proclus, In Timaeum, 3 p. 231.5-11.

113 Proclus, In Timaeum, 3·335, 3·338, 3.340.

114 Proclus, In Timaeum, 2.119-132. Origen applied a similar notion to the generation of the Son, who in his view is coeternal with the Father because its generation is eternal, not so 
Precisely in the Timaeus, $36 \mathrm{Bff}$., Plato spoke of circles in the soul. For Proclus, the cyclic period of the human soul is "its proper life" (Elements of Theology 199, on which see below, and 200). This conception squares perfectly with his restoration-return-reversion scheme. The Neoplatonic use of $\dot{\pi} \pi \sigma \tau \rho \circ \varphi \eta$, which in Proclus parallels that of $\dot{\alpha} \pi \circ x \alpha \tau \dot{\alpha} \sigma \tau \alpha \sigma i \varsigma$, must indeed be seen within the tri-

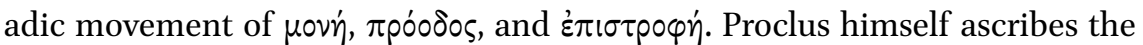
theorisation of this movement to Iamblichus in In Timaeum 2.215.5: the Monad is the principle of identity and the moment of immanence, the Dyad introduces procession, and the Triad is the origin of reversion or return. Procession, according to Proclus, is a movement from better to worse, reversion from worse to better (Elements of Theology 36 -37; cf. Plotinus, Enneads, 5.8.1, 6.9.9).

According to Proclus, only what is incorporeal and without parts, such as the

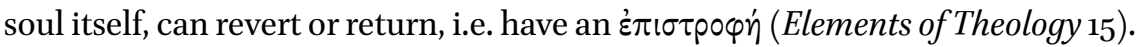
The body does not revert, which implies that there is no resurrection of bodies. This is in line with "pagan" Platonism, more than with Christian Platonism.

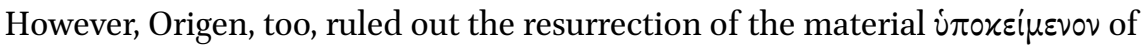
a body, which is permanently in flux, and only admitted of the resurrection of the عiठos or metaphysical form of the earthly body, transformed into a spiritual body; so also the Christian Neoplatonists Gregory of Nyssa and Evagrius. ${ }^{115}$ Indeed, for Origen, Gregory, and Evagrius the resurrection is part and parcel of the restoration process, which involves the soul and the intellect as well as the body (for Evagrius, the body will be elevated to the level of soul and the latter to the level of intellect). ${ }^{116}$

The link between reversion ( $\dot{\varepsilon} \pi \iota \tau \rho \circ \varphi \eta \dot{\eta})$ and restoration ( $\dot{\alpha} \pi \circ x \alpha \tau \dot{\alpha} \sigma \tau \alpha \sigma \iota)$ is manifest especially in the case of souls and is made clear especially in In

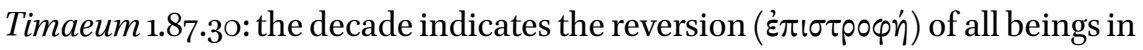
the cosmos toward the One; the ninety indicates the restoration ( $\dot{\alpha} \pi \circ \kappa \alpha \tau \dot{\alpha} \sigma \tau \alpha-$ $\sigma(\varsigma)$ to the monad next to the procession $\left(\pi\right.$ póodos). ${ }^{117}$ Like reversion, restoration too is posited next to procession. Indeed, as I have pointed out, in Dionysius, who was impacted by Proclus a great deal, the restoration is understood as a reversion and is sometimes explicitly represented as such. In the Elements of Theology 32, Proclus observes that the return/reversion of the soul, of which

much in the sense that the Son continually receives the power to exist, as in the sense that the generation of the Son transcends time.

115 See Ramelli 2008b; Ramelli 2007a, and further Ramelli 2019b. For Evagrius, Ramelli 2015c.

116 On Evagrius' ideas about the resurrection and about bodies, see Ramelli $2015 \mathrm{c}$ and Ramelli 2017 d.

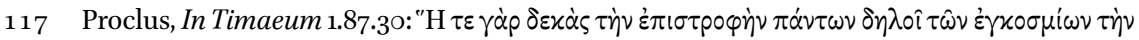

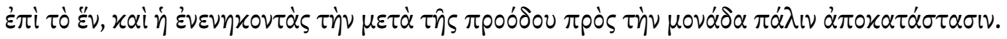


Porphyry was speaking in De regressu animae (according to the title reported by Augustine) and which parallels Origen's notion of apokatastasis, "is accomplished by virtue of likeness" to the highest principle. Now, this takes place thanks to virtue: for apokatastasis is common to both "souls" and "mortal animals," but with different modalities, since for souls alone it depends on life "according to virtue" ( $\varkappa \alpha \tau$ ' $\alpha \rho \varepsilon \tau \dot{\nu} \nu \zeta \omega \dot{\eta}$, In Cratylum 179.36-37). ${ }^{118}$

Remarkably, that apokatastasis is made possible only by the active pursuit of likeness to God, the first principle, in a life of virtue was a major tenet of Origen's theory of apokatastasis. Origen drew a distinction between being in the image ( $\varepsilon i x(\omega)$ ) of God, which is an initial datum for every human intellectual soul, and becoming in the likeness ( $\left.\dot{\mu} \mu o^{\prime} \omega \sigma / \zeta\right)$ of God, which passes through a personal effort and engagement in virtue, and is perfected only at apokatastasis, in the telos or ultimate end, the accomplishment of all. ${ }^{119}$ In the Elements of Theology 32, Proclus proposes this general principle: "Every return/reversion is perfectly achieved by means of the likeness of those who return to

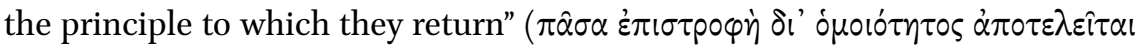

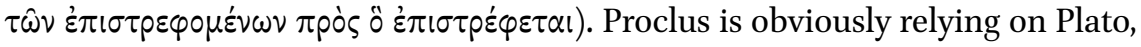
Theaetetus $176 \mathrm{~B}$, on the ethical tenet of $\delta \mu o i \omega \sigma \iota \varsigma \theta \varepsilon \hat{\omega}$; Origen, as often, relies on both Plato and Scripture (Gen 1:26-27), but neither source includes the specific idea that the return/reversion or restoration will be through likeness. This is instead found in Origen and in Proclus. The latter read in Plotinus that likeness is a fundamental presupposition of all knowledge (Enneads 1.8.1, reflected in Proclus In Timaeum 2.298.27; 3.160.18), and interpreted knowledge as a type of return/reversion (In Timaeum 2.287.1). Salustius, the Neoplatonist close to Emperor Julian, relates the idea of likeness to the voluntary adhesion to the divine, as Origen also did: "When we are good we attach ourselves to the gods

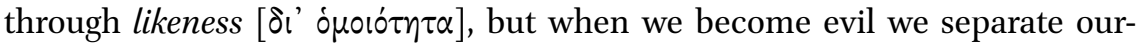
selves from them through unlikeness [ $\left.\delta \iota^{\prime} \alpha \dot{\nu} \sigma \mu o{ }^{\prime} \tau \eta \tau \alpha\right]$." Dionysius, the Christian Platonist who was very well acquainted with both Origen and Proclus, ${ }^{120}$ maintained likewise that likeness is the motor of the return or reversion, which he related to apokatastasis: "The power of the divine likeness is that which has all beings return [żं $ı \tau \tau \rho \dot{\varepsilon} \varphi 0 v \sigma \alpha]$ to their Cause" (Divine Names 9.6).

Proclus seems to have had Origen's theory of apokatastasis at the back of his mind, all the more so if one considers that in the immediately following proposition in his Elements of Theology (33) Proclus enunciates another prin-

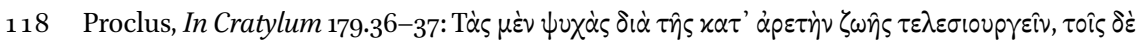

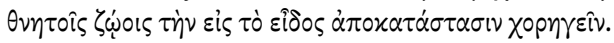

119 See Ramelli 2013a, section on Origen.

120 See above and Ramelli forthcoming- g. and Ramelli forthcoming- e. 
ciple that was also a primary pillar of Origen's doctrine of apokatastasis and, as I shall observe momentarily, and was also enunciated by Plotinus, namely that the reversion / return / restoration / apokatastasis joins the end ( $\tau \dot{\varepsilon} \lambda \circ \varsigma)$ to

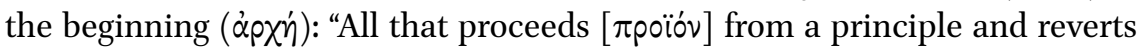

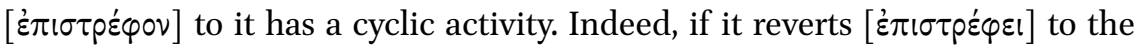

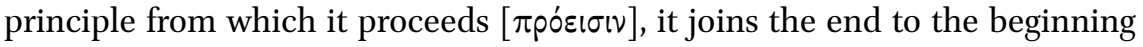

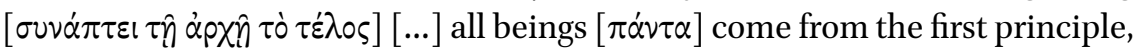
and all revert to it." Proclus proclaims the universality of the reversion/restoration and is certainly in full agreement with Origen's doctrine of universal, and not partial, restoration. The main difference is that Proclus envisages infinite beginnings ( $\dot{\alpha} p \chi \alpha \dot{i})$ and infinite ends $(\tau \dot{\varepsilon} \lambda \eta)$, because infinite are the returns and the apokatastatic cycles in his system, while Origen, although he admits of

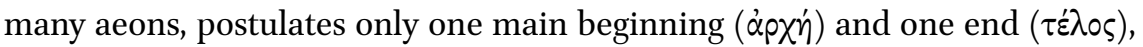
which comes after the end of all aeons. The tenet which connects the $\tau \dot{\varepsilon} \lambda$ ○ऽ to the $\alpha p x \eta^{\prime}$ began to be voiced at the time of Origen, and precisely by his fellow disciple Plotinus: "for all beings the beginning is also the end," $\tau \varepsilon \dot{\lambda}$ os $\ddot{\alpha} \pi \alpha \sigma \nu \dot{\eta}$

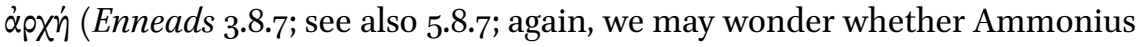
Saccas was interested in apokatastasis or reversion and how he characterized it). Later, this principle returns in Iamblichus (Myst. 31.16) and Syrianus, Proclus' teacher (In Metaphysica 38.3). In this way, we can trace a whole trajectory in Platonism, which includes not only 'pagan' but also Christian Platonism (Origen, Gregory of Nyssa, Evagrius, Dionysius, Eriugena).

Furthermore, one proposition later, in the Elements of Theology 35, yet another tenet of Origen's restoration theory appears: that the reversion / restoration is to oix $x \hat{i} \alpha$, that is, to what is proper and familiar to someone; this concept is reiterated at In Rempublicam 2.162.10: "each being must absolutely be restored [ $\pi \dot{\alpha} v \tau \omega \varsigma \dot{\alpha} \pi \circ \kappa \alpha \theta i \sigma \tau \alpha \sigma \theta \alpha l]$ to the wholeness that is proper and familiar

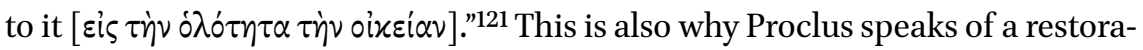

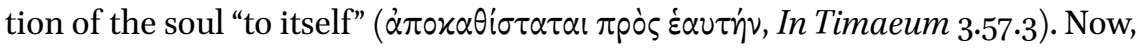
another remarkable parallel between Proclus and Origen with regard to the notion of return/reversion and apokatastasis concerns precisely the conceptualisation of apokatastasis as oikeiōsis. Origen, as I hopefully demonstrated elsewhere, ${ }^{122}$ was the first who firmly established this link, which was then taken over by Gregory of Nyssa. ${ }^{123}$ He maintained that apokatastasis is an oikeiōsis

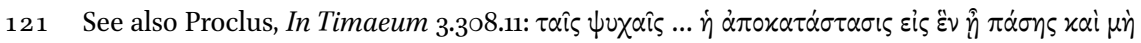

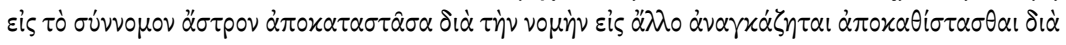

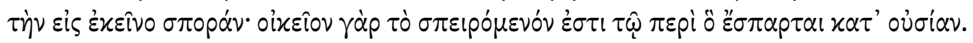

122 Ramelli 2014d.

123 For Gregory see Ramelli 2014e. 
because "the restoration is to a condition that is proper and familiar" to the

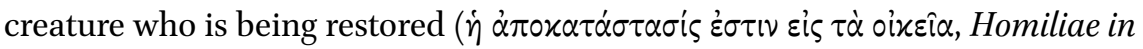
Ieremiam 14.18). No creature can be restored to a condition that is alien to it and does not belong to its very nature and primordial state (note that for Gregory of Nyssa, as for Origen, creatures are all beings apart from God. The Creator, and evil and death, which were not created by God, but are rather consequences of wrong choices—sins — of rational creatures endowed with free will). Likewise, in the Elements of Theology 35, Proclus arguing for the necessity that immanence, procession and return be always present, all of them, excludes that there

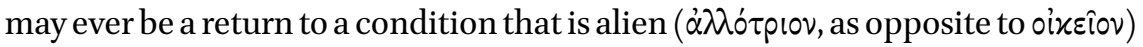
to the being that is returning: "If it should return only (without immanence or procession), how could that which has not its essence from that cause make the

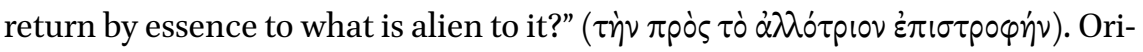
gen, followed by Gregory of Nyssa, also supported the same idea. The steps of the reversion, as Proclus observes, mirror those of the procession: "Every reversion passes through the same terms as the corresponding procession" (Elements of Theology 38 ).

In Elements of Theology 39, Proclus introduces his Noetic Triad, of which I have spoken at the beginning, and applies it to his theory of reversion. He thus claims that reversion is applied to all beings, but to various degrees:

(1) inanimate beings revert only in their being;

(2) animate but irrational beings revert in their life as well; and

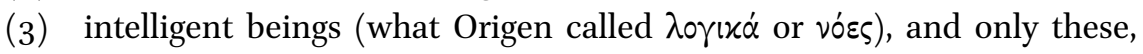
revert in their knowledge.

In Theologia Platonica 3.6.22.19-23 Proclus explains that Life is participated in by all animate beings, including those which have no share in knowledge, while Nous (Intellect) is only participated in by beings that are capable of knowledge. It results that Life irradiates its gifts to more beings than Intellect does. Clearly, Proclus is here using his Noetic Triad: Being, Life, and Nous, which can be conceptualized as three concentric circles, the first being the largest and the last the smallest.

It is interesting that a similar, concentric triad as mentioned, was applied by Origen in Princ. 1.3.5-6, which is recapitulated in 1.3.8 - a work very probably known to Proclus. For Origen,

(1) all existing beings (omnia omnino quae sunt), i.e. all creatures participate in God the Father and Creator, on account of their very existence, since God is Being;

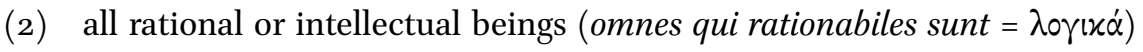
participate in Christ-Logos; and

(3) the saints alone (sancti) participate in the Holy Spirit. 
This triad by Origen, like Proclus' Noetic Triad, can be conceptualized as three concentrical circles, the first being the largest and the last the smallest.

Affinities and discrepancies between Proclus' and Origen's conceptions of apokatastasis emerge nicely from Proclus' Elements of Theology 146 : in the cycle of procession and reversion "the end is similar to the beginning" ( $\tau \dot{\alpha} \tau \dot{\varepsilon} \lambda \eta \pi \rho \dot{s}$

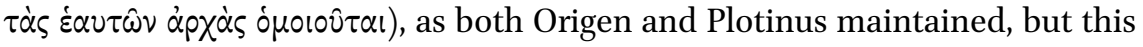
process also forms a cycle that "has no beginning and no end" ( $\alpha$ vapXov xai $\dot{\alpha} \tau \varepsilon \lambda \varepsilon \dot{\tau} \tau \eta \tau o v)$. If Origen maintained that the end will be "similar to the beginning" exactly like Proclus, nevertheless Origen, unlike Proclus, did not posit infinite cycles of reversion, because he postulated, on the basis of Scripture, both a creation in time and an end of time, so that after apokatastasis, at the end of a limited number of aeons, there will be no new beginning. He made this clear especially in his above-mentioned polemic against the Stoic theory of apokatastasis, but also in his use of the Pauline words, "Love never falls (out)," in support of the definitive and eternal nature of the eventual apokatastasis. ${ }^{124}$

The same divergence in cosmology and philosophy of history between Origen and Proclus emerges again from the following passage, In Rempublicam $2.21 .22 ; 2.20 .5$, in which Proclus expressly speaks of apokatastasis. The supreme divinity, to whom the monad belongs, according to Proclus is the very cause of every apokatastasis. ${ }^{125}$ Origen too regarded the supreme divinity, God as "Monad and Henad" (Princ. 1.1.6), as the cause and the ultimate end of universal apokatastasis, but he thought that, once all rational beings have returned to God and achieved unity with God, there will be no new cycle: no rational creature will turn away again from God and therefore need to be restored again. Moreover, the same difference between Proclus and Origen emerges once more in another point, the following. Like Origen, ${ }^{126}$ Proclus too relates apokatastasis to eternal life, after purification (In Rempublicam 2.185.6). ${ }^{127}$ But according to Origen the attainment of eternal life takes place once and for all for each individual, while Proclus envisages infinite cycles between eternal life and the world of generation. This divergence emerges again and again.

A convergence between Proclus' doctrine of apokatastasis and that of Origen concerns the notion that all that which is not already in actuality needs

\footnotetext{
124 Ramelli 2013a, ch. 1 and chapter on Origen; Ramelli 2019d, chapter on Origen.

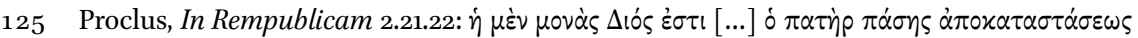

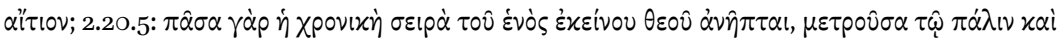

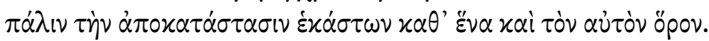

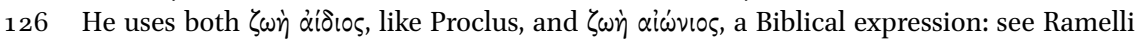
2008c.

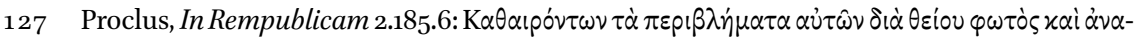

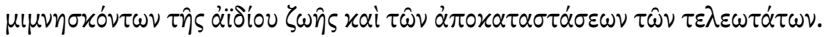


time to reach perfection and restoration, by adhering to the Good and collecting all of its own goodness ("Quantunque in creatura è di bontate," as Dante would say in his prayer to the Virgin Mary in his Paradise). ${ }^{128}$ The very same idea was also found in Origen: apokatastasis can be reached only by adhesion to the Good and by rejecting all evil and collecting all the good that can be present in oneself; now this path toward perfection and restoration takes time. In addition, both Origen and Proclus identify perfection and restoration. This is also why Origen postulated a series of whole aeons before the eventual apokatastasis, to give time to all to reach their perfection. But this is also where the difference between Proclus and Origen lies, once again: for Origen there will be one and only one universal restoration at the end of all aeons, whereas for Proclus the restorations are infinite, just as time is infinite: there will be no "end of the world."

Proclus, as pointed out above and as emerges again here, explicitly speaks of apokatastasis and not only of reversion. According to Theologia Platonica 3.33.13, "The soul measures its own life by cycles of restoration" ( $\dot{\eta} \psi v \chi \dot{\eta} \tau \hat{\omega} \mu \dot{\varepsilon} \nu$

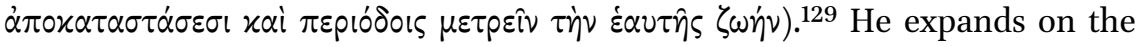
restoration or apokatastasis of the soul in the Elements of Theology 199:

Every soul that is in the cosmos has cycles and restorations of her own,

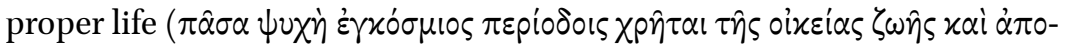
$\chi \alpha \tau \alpha \sigma \tau \dot{\alpha} \sigma \varepsilon \sigma(v)$. For if it is measured by time and operates in a transitive way, ${ }^{130}$ and movement is proper to it, ${ }^{131}$ and all that which moves and

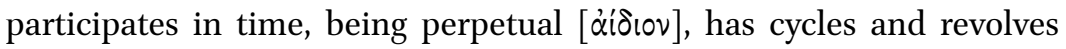

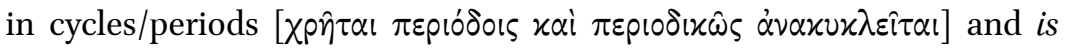

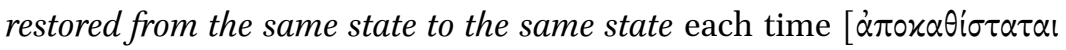
$\dot{\alpha} \pi \dot{\partial} \tau \hat{\omega} \nu \alpha \dot{v} \tau \hat{\omega} \nu \dot{\varepsilon} \pi \dot{i} \tau \dot{\alpha} \alpha \dot{\nu} \tau \dot{\alpha}],{ }^{132}$ then it is clear that every soul that is in the cosmos, having movement and operating in time, will have cycles of

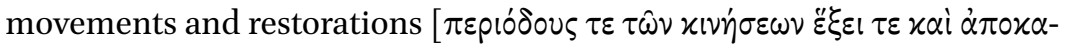
$\tau \alpha \sigma \tau \dot{\sigma} \sigma \varepsilon ı \zeta]$. For every cycle of perpetual beings involves a restoration $[\pi \hat{\sigma} \sigma \alpha$

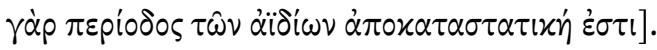

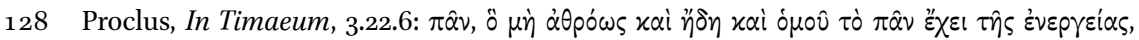

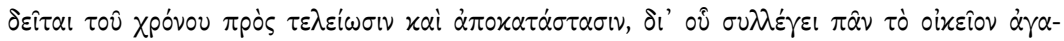
tóv.

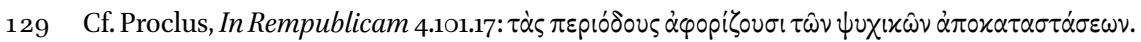

130 Cf. Proclus, Elementatio theologica, 191.

131 Cf. Proclus, Elementatio theologica, 20.

132 Cf. Proclus, Elementatio theologica, 198. 
The link between apokatastasis (of souls and heavenly bodies) and cyclical periods occurs often in Proclus, ${ }^{133}$ who also attributes this theory to Egyptians and Chaldaeans. ${ }^{134}$ Among the "perpetual beings" of which Proclus speaks in the block quotation above as subject to apokatastasis there are certainly rational souls. Origen classified as rational souls ( $\lambda$ orix $\alpha$, rational beings or rational

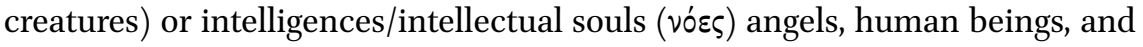
demons. All rational creatures originally enjoyed the same state of beatitude and were not differentiated into classes; they were not different by nature, but became differentiated into angels, human, and demons due to the choices of their free will. ${ }^{135}$ Porphyry was well acquainted with Origen's theory of $\lambda \circ \gamma(x \alpha$, and in his Letter to Anebo asked exactly which factors distinguish gods, daemons, heroes, and souls from one another. ${ }^{136}$ In In Timaeum 1.142.1, Proclus defines daemons as "souls that are neither divine nor susceptible of transformation," but in 3.165.11 he further classifies these into angels, daemons proper,

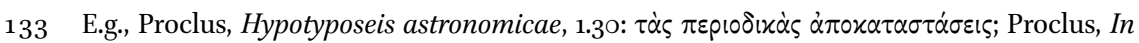

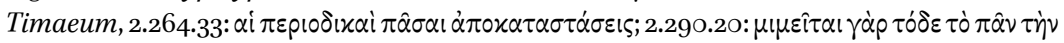

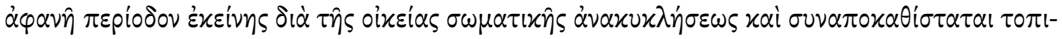

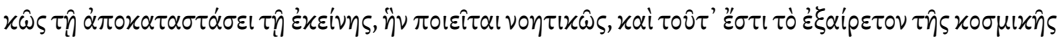

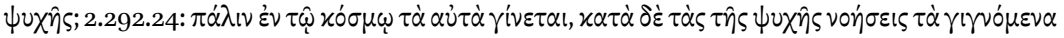

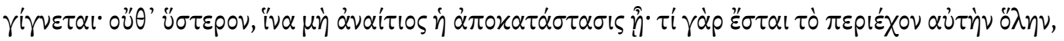

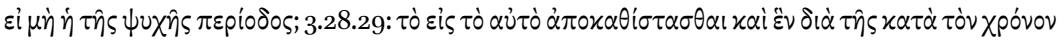

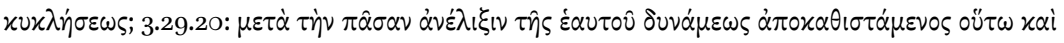

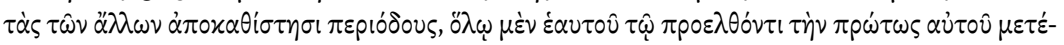

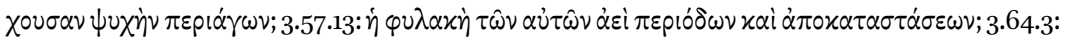

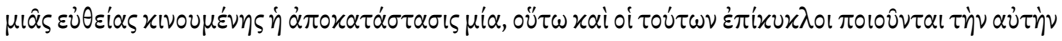

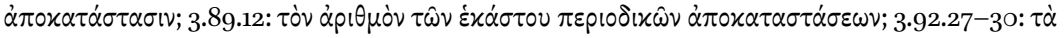

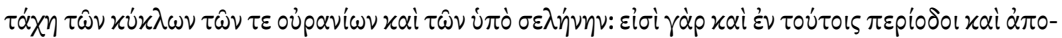

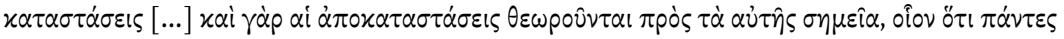

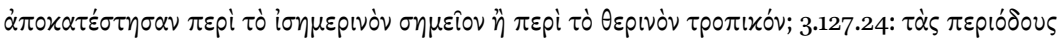

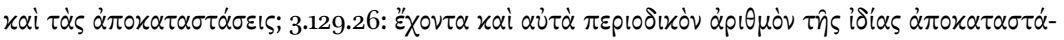

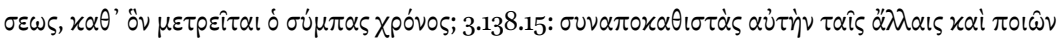

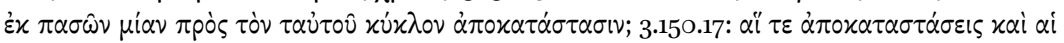

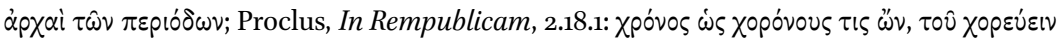

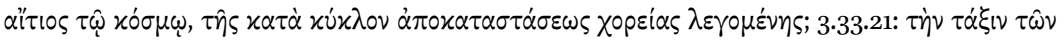

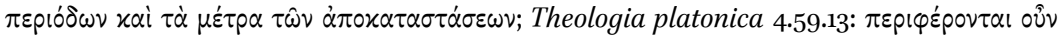

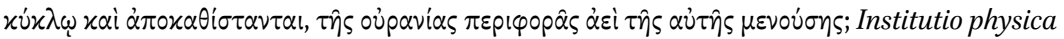

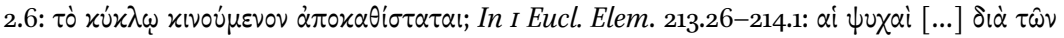

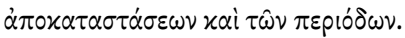

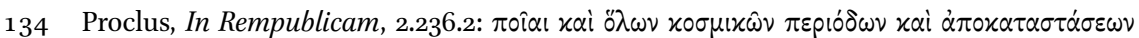

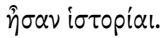

135 Full analysis in Ramelli 2013a, section on Origen; Ramelli 2013d.

136 Ap. Iamblichus, Myst. 61.11; 67.1. On this work see now the new edition and essays by Saffrey and Segonds (in Porphyre, Lettre à Anébon l'Égyptien). Now also Iamblichus's response is available in the same series Saffrey, Segonds 2013. Study of both in Addey 2014. 
and heroes ( $\left.\ddot{\alpha} \gamma \varepsilon \lambda_{0} 01, \delta \alpha i \mu \circ v \varepsilon \varsigma, \ddot{\eta} \rho \omega \varepsilon \varsigma\right)$. This tripartition was already present in the Middle Platonist Celsus and Origen (Cels. 7.78). Origen, a prominent disciple of Ammonius Saccas, and never distinguished by any ancient source from the Christian Origen, is also attributed a specific treatise On Daemons or On Rational Creatures. ${ }^{137}$

Proclus in the Elements of Theology 198 details the cyclical and perpetual nature of the movement of restoration: "Every being that participates in time

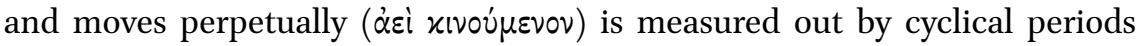

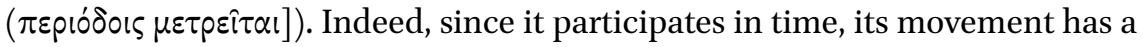
share in measure and limit, and it proceeds according to number. And since it moves perpetually [ $\dot{\alpha} \varepsilon \dot{i}]$, and this perpetuity does not transcend time but

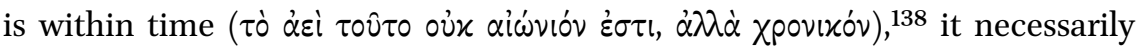
has cyclic periods [...]. What moves perpetually cannot be transformed for a limited number of times. Therefore, what moves perpetually will return again and again from the same state to the same state, so as to form a cyclic period

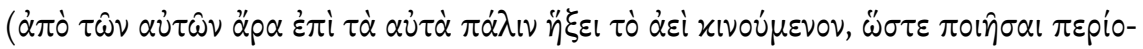

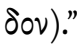

The perpetuity and infinity of this cyclical movement is what primarily distinguishes Proclus' theory of apokatastasis from that of Origen. It is highlighted by Proclus many times throughout his works, for instance in In Timaeum 3.18.16

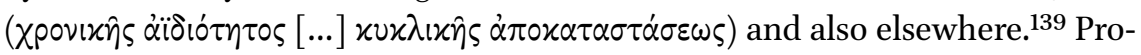
clus opposes the apokatastasis of the soul to the world of generation and becoming. He distinguishes two arrangements of things: the better, harmonic, tends to the restoration of the soul, the other to the cycles of rebirth into

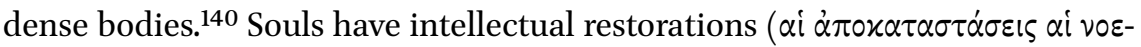

137 Arguments for the possible attribution of this treatise to Origen the Christian Platonist in Ramelli 2009a and in a work in preparation.

${ }_{13} 8$ For the meaning of $\alpha i \omega v$ vos as "transcending time" in the Platonic tradition and the difference from $\alpha i$ ì 10 s see Ramelli, Konstan 2007, and the reviews by O'Brien 2010 and Ghira 2009 .

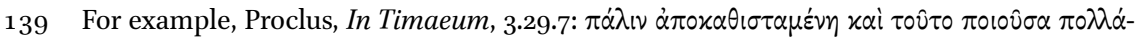

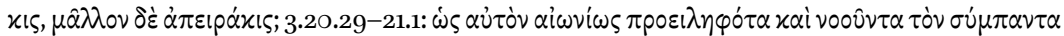

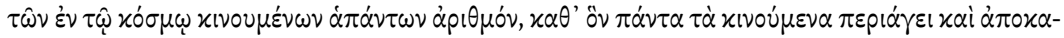

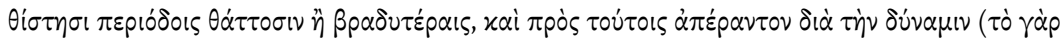

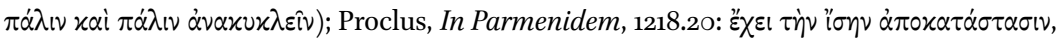

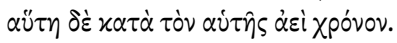

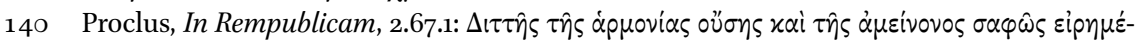

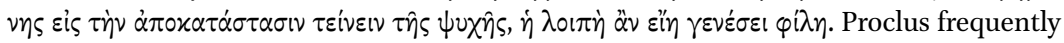

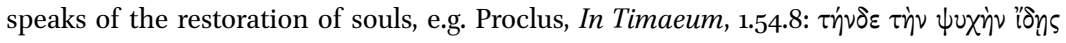
$\dot{\alpha} \pi \circ \kappa \alpha \tau \alpha \sigma \tau \hat{\sigma} \sigma \alpha \nu$. 
pai), which cannot be perceived by senses. ${ }^{141}$ Each soul has its own periods and restorations, and differences among these are due to partial souls' life in time:

Every cyclic period of the soul is measured by time, but that of the other souls is measured by a certain time, while the cyclic period of the first soul is measured by the totality of time ( $\tau \hat{\omega} \sigma u ́ \mu \pi \alpha v \tau \iota \chi \rho o ́ v \omega)$. For, if all movements entail a "first" and an "after," cyclic periods too, then, do. And for this reason they participate in time, and time is what measures all the cyclic periods of the soul. Now, if the periods were the same for all souls, and all had the same vicissitudes, the time, too, would be the same for all of them. But if their restorations are different from one another ( $\alpha \dot{\lambda} \lambda \alpha \mathrm{\alpha} \alpha \lambda \omega \omega \nu \dot{\alpha} \pi 0-$ $\varkappa \alpha \tau \alpha \sigma \tau \dot{\alpha} \sigma \varepsilon ı \zeta)$, the time of their cyclic periods, too, and their restorations will vary [...]. All other souls (apart from the world soul) are measured by given measures that are more limited than the whole of time. This is clear from the following consideration. If those souls are more limited than the soul which participates in time primarily, they will not adapt their periods to the totality of time either, but their many restorations will

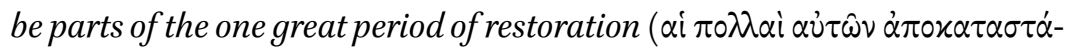

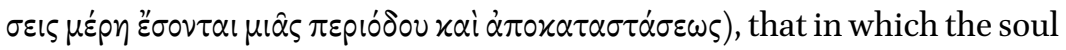
that primarily participates in time is restored ( $\ddot{\eta} \nu \dot{\eta}$ Xpóvov $\mu \varepsilon \tau \dot{\chi} \chi 0 v \sigma \alpha \pi \rho \dot{\omega}-$ $\tau \omega \varsigma \dot{\alpha} \pi \circ \alpha \alpha \theta i \sigma \tau \alpha \tau \alpha l)$. Indeed, the more limited participation characterises a lesser power, the more universal characterises a greater power. Therefore, the other souls cannot by nature receive the full measure of time during one single life, because they have been assigned a place subordinate to that soul which is measured by time primarily (Elements of Theology 200).

Each individual soul has its apokatastasis, each one different from those of other partial souls, but the world soul, whose cyclic period is measured by the totality of time, has an apokatastasis that coincides with one great period. Proclus hammered home in many passages this theory that the partial restorations of single souls, each one covering a fraction of time, constitute the universal restoration, which coincides with the totality of time. ${ }^{142}$ In this way, Proclus postulates different measures and cyclic periods for the restorations of partial

\footnotetext{
141 Proclus, In Timaeum, 3.149.26; 3.308.22.

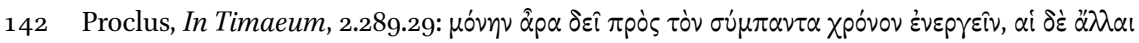

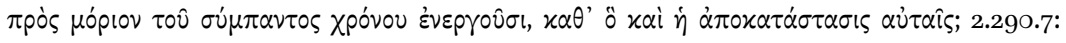

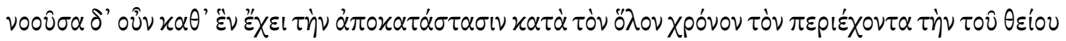

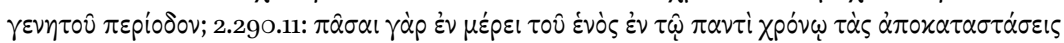

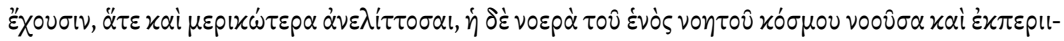


souls and bodies, but one single measure and one big period for the universal restoration. ${ }^{143}$ Partial souls and bodies have different paces, slower or faster, in their periodic restorations, ${ }^{144}$ but they are all unified in the cosmic restoration. As Proclus clarifies, "with its own restoration, the world soul restores the whole

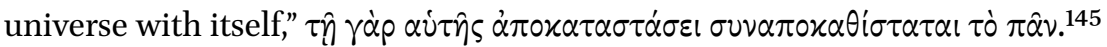

It must be noted that the totality of time which coincides with a single cyclic period of the world soul, of which Proclus speaks in the Elements of Theology 200 cannot be an infinite time (given that a cycle must be finite), but a cosmic cycle, which concludes with a cosmic apokatastasis, that is, the restoration not of one partial soul, but of all partial souls together. This cosmic apokatastasis, coinciding with the great year, is the apokatastasis of the world soul, which includes the restoration of all other souls, and in Proclus' scheme (different here from that of Origen) recurs perpetually:

Time, revolving upon itself in a circle, is restored ( $\dot{\alpha} \pi \circ \alpha \alpha \theta \sigma \tau \dot{\alpha} \mu \varepsilon v \circ \varsigma)$ together with the whole revolving of its own power, and thus it also

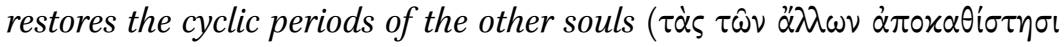

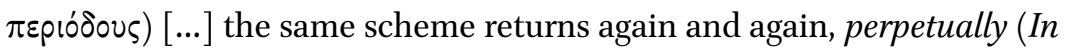
Timaeum 3.29.18);

The totality of time is the complete number of the restoration of the

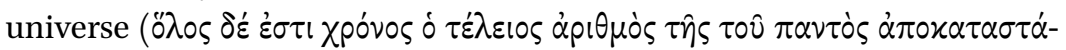
$\sigma \omega \varsigma$ ) (In Timaeum 3.95.6).

Proclus describes time ( $\delta$ × tastasis of all movements, corporeal and incorporeal" ( $\tau \hat{\eta} \varsigma \tau \hat{\omega} \nu \dot{\varepsilon} \nu \alpha \dot{\nu} \tau \hat{\omega} \pi \dot{\alpha} v \tau \omega \nu$

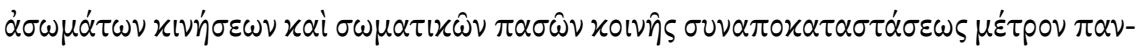

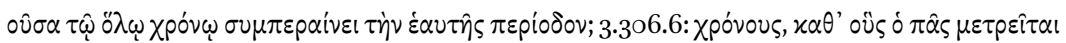

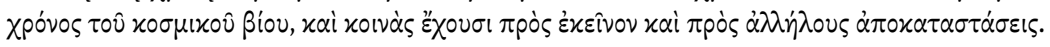

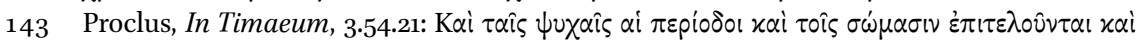

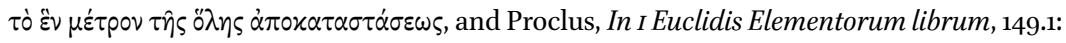

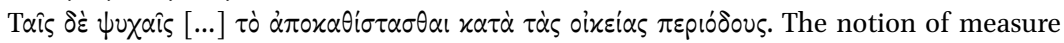
is intrinsic to the periodic movement of apokatastasis: Proclus, In Rempublicam, 2.18.17: $\dot{\alpha} \pi \circ \kappa \alpha \theta 1 \sigma \tau \dot{\alpha} \varsigma \pi \dot{\alpha} \nu \tau \alpha \varkappa \alpha \tau \dot{\alpha} \tau \dot{\alpha} \dot{\varepsilon} \alpha \nu \tau \hat{\omega} \sigma \dot{\mu} \mu \varphi v \tau \alpha \mu \dot{\varepsilon} \tau \rho \alpha$.

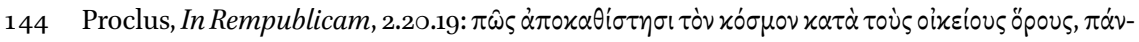

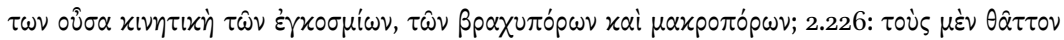

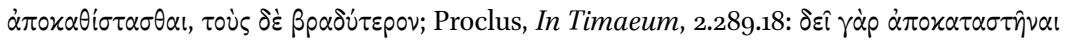

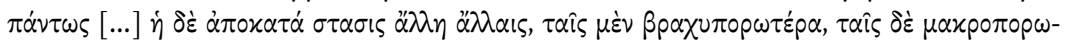

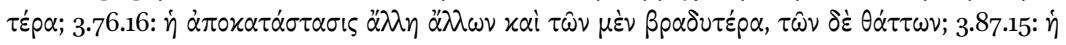

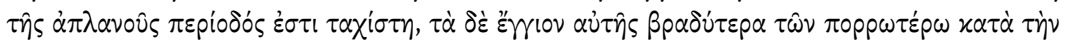
$\dot{\alpha} \pi 0 x \alpha \tau \dot{\alpha} \sigma \tau \alpha \sigma \nu$.

145 Proclus, In Timaeum, 2.292.21. 


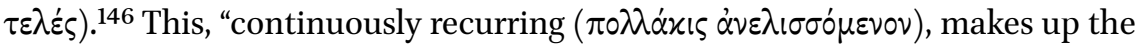

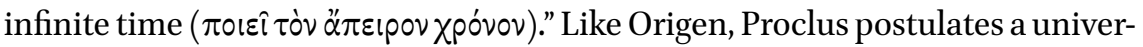
sal apokatastasis, but, once again unlike him, Proclus thinks that this apokatastasis does not happen once and for all at the end of time, but repeats itself infinite times, although over extremely long cycles. For the universe itself is imperishable, it was not created in time and therefore will never perish at a certain point in time: "the entire time embraces the whole life of the apokatastasis of the universe. What does not perish within this time is imperishable. Indeed, nothing perishable can endure for the totality of time."147

Such a theory of cosmic cycles, each one concluding with an apokatastasis, seems to have been already present in Middle Platonism, which in turn assimilated this element from Stoicism. It is no chance that Origen, well steeped in Middle Platonism, felt the need to criticise the Stoic doctrine of apokatastasis, as I have mentioned, so as to emphasise the main differences between it and his own Christian theory of apokatastasis. The Middle Platonists probably projected the Stoic doctrine of apokatastasis into Plato's Politicus myth. Actually, I suspect that this myth influenced the Stoic theory of apokatastasis itself. ${ }^{148}$

According to Proclus, a cyclic period of a human soul (which is much shorter than the great, cosmic period) does not seem to coincide with one single human life, but with a cycle that begins with the descent of the soul and ends with its restoration to contemplation. Depending on the soul's moral choices, such a cycle may embrace a series of human lives.

In Plato's Phaedrus 248E ff. the minimum interval is said to be 3000 years, encompassing three incarnations of the soul. Plato in Timaeus $42 \mathrm{~B}$ seems to admit that the return of a soul to the appropriate star can occur after one incarnation only. Proclus, however, in In Timaeum 3.291 remarks that this is not a complete $\dot{\alpha} \pi \circ x \alpha \tau \dot{\alpha} \sigma \tau \alpha \sigma \zeta$. Thus, it appears that he envisages a much longer cycle. This entire theory will have to be investigated more thoroughly within a systematic analysis of philosophical notions of apokatastasis, from the Presocratic, Plato, Aristotle and the Stoics to imperial and late antique Platonism (and their comparison with patristic doctrines of apokatastasis).

146 Proclus, In Rempublicam, 2.11.25. That universal apokatastasis is both bodily and noetic

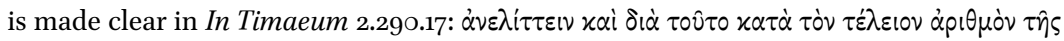

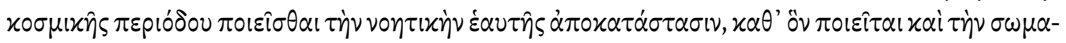
$\tau\llcorner x \dot{\eta} \nu$ ö $\lambda \eta \nu \pi \varepsilon p i ́ o \delta$ ov.

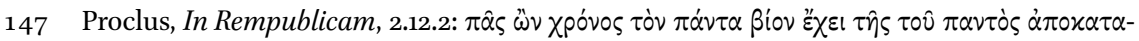

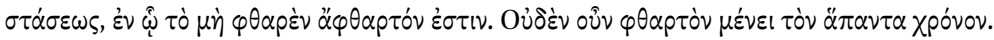

148 A specific work will be devoted to this investigation. 


\section{$4 \quad$ Proclus and Origen on Bodies, Vehicles, Souls, Matter and Evil}

Proclus, just as Origen beforehand, connected the concepts of apokatastasis and reversion, which concern primarily souls, to the theory of the soul-body relation ${ }^{149}$ and the vehicles of the soul. It will be necessary to investigate briefly Proclus' doctrine of the soul's corporeal vehicle, different from Plotinus' doctrine, and a comparison will have to be drawn with Christian Platonists such as Origen and Gregory of Nyssa (Evagrius would also be very interesting to examine here, but Proclus may have known only Origen among these thinkers).

In Proclus' view, the soul, entering a cyclic apokatastatic period, acquires a second vehicle (" $\not \eta \eta \mu \alpha)$, after the immaterial and immortal one of which he speaks in the Elements of Theology 208 and which represents a remarkable similarity with Origen's anthropology (see below). The soul's second vehicle is in turn different from the mortal body. At the stage of apokatastasis, the soul will be purified and freed from the second vehicle as well as from the heavy body. ${ }^{150}$

From the Christian side of Platonism, Origen also postulated such degrees from an immortal to a mortal, heavy body and seems to have posited a permanent first body like Proclus. According to Origen, a spiritual body was created with each nous at the beginning of its substantial existence and then gets transformed according to the moral choices of the rational, intellectual creature. ${ }^{151}$ In the Elements of Theology 208, Proclus describes the first vehicle of the soul: "The vehicle ("o $\chi \eta \mu \alpha)$ of every partial soul is immaterial ( $\alpha \ddot{u} \lambda \circ v)$, indivisible by essence, and not subject to passions." This corresponds to the spiritual body postulated by Origen, which all noes / logika had at the very beginning of their creation (when God created both them and matter), an impassible body which served as a vehicle of the rational soul. ${ }^{152}$

Plotinus also spoke of a "luminous vehicle" ( $\alpha \dot{\gamma} \gamma o \varepsilon 1 \delta \dot{\varepsilon} \varsigma$ "ö $\chi \eta \mu \alpha)$, which souls assume in their descent in Treatises 14, 26, and 27. Origen, Plotinus' fellow disciple at the school of Ammonius in Alexandria, as mentioned, very probably deemed rational creatures to be endowed, from the start of their existence as substances, with a subtle body, which may (in the case of humans) or may not (in the case of angels) become a heavy and mortal body on account of their sin. There even seems to be a verbal resonance between Origen and Plotinus:

\footnotetext{
149 On Proclus' ideas on the soul-body relation, see Opsomer 2018.

150 Proclus, In Timaeum, 3.237.

151 On Origen on degrees of corporeality and soul(s), documentation in Ramelli 2013e; further documentation and arguments in Ramelli 2018b. A full treatment will be devoted to this issue in a chapter on anthropology in Origen.

$15^{2}$ As pointed out by Ramelli 2018b.
} 
Origen also designated the subtle and spiritual body of rational creatures as

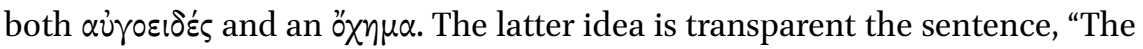
soul is said to have first used the luminous body as a vehicle; later this was cov-

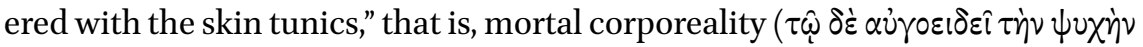

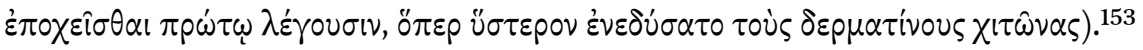

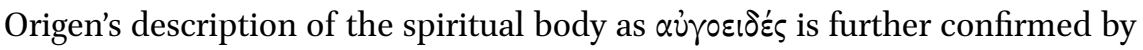
the sixth-century theologian Gobar. ${ }^{154}$

As Origen rejected the theory of the preexistence of "bare" souls without any corporeal vehicle whatsoever, Proclus also thinks that every soul always has an immaterial, simple, and impassible vehicle. Origen regards both the rational / intellectual soul and its immortal body as created by God at a certain point and not coeternal with God (coeternal with God are only the Forms / Ideas / Logoi of all rational creatures in the Mind of God, who is Christ-Logos-Wisdom ${ }^{155}$ ). In the Elements of Theology 207, Proclus also speaks of the soul and its immortal vehicle as created ("the vehicle (" $\chi \chi \eta \mu \alpha)$ of every partial soul has been created

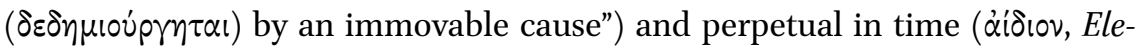
ments of Theology 208 and 196), albeit not eternal in the sense of transcending time: the latter is the meaning of aíuvios in Platonism. ${ }^{156}$

In the Elements of Theology 196 Proclus clarifies that the immaterial, invisible, and impassible vehicle of the soul is actually an immortal body, which here he characterizes as $\dot{\alpha} \gamma \varepsilon \dot{\varepsilon} \varepsilon \tau 0 v$. This should not be taken in the sense that this bodily vehicle is uncreated, which would contradict Proclus' Elements of Theology 207, but in the sense that it has no beginning in time (otherwise it should also have an end in time, as required by the perishability axiom, which Gregory of Nyssa arguably used $\left.{ }^{157}\right)$ :

Every participated soul uses at first a body, which is perpetual/perennial and has a constitution without beginning in time and incorruptible $(\pi \hat{\alpha} \sigma \alpha$

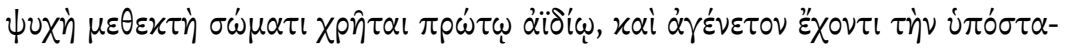
$\sigma \nu v \alpha i \dot{\alpha} \varphi \theta \alpha p \tau o v)$. For, if every soul is perpetual / eternal by essence $\left(\kappa \alpha \tau \tau^{\prime}\right.$

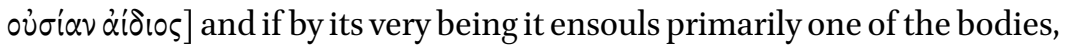
it will ensoul it always ( $\dot{\alpha} \varepsilon \dot{)})$; for the being of every soul is unchangeable. If so, the body ensouled by it is in turn always ( $\dot{\alpha} \varepsilon \dot{i})$ ensouled and always participates in life. Now, what lives always much more exists always. But

153 Ap. Procopius, Comm. in Gen. PG 87/1.221A.

154 Ap. Photius, Bibliotheca cod. 232.288A.

155 See Ramelli forthcoming- $b$.

156 Ramelli, Konstan 2007, p. 22-38.

157 For Gregory, see Ramelli 2018g. 


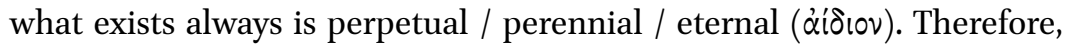
the body that is at first ensouled and attached to any soul is perpetual / perennial / eternal ( $\alpha i \delta i o v)$. But every participated soul is at first participated by a body, if it is true that it is participated and not unparticipated, and by its very being ensouls the body that participates in it. Therefore, every soul that is participated uses at first a body that is perpetual / perennial / eternal (äioi i $\omega)$, not created in time, and incorruptible by essence.

According to the perishability axiom, well known to all Neoplatonists, 'pagan' and Christian alike, the spiritual body, being not created in time, and being not composed, will not decay, nor have an end in time. Although they all knew the ó $\eta \mu \alpha$ theory, however, unlike Plotinus' or Porphyry's, Proclus' position that a soul perpetually uses a body as a vehicle, from the very beginning and independently of its descent or fall, comes remarkably close to that of Origen. Like Origen, also, Proclus thinks that angels have a spiritual body, which per se has no shape (they are áuóp $\varphi \omega \tau o l)$ but can take on a shape when they condescendingly appear to human beings $\dot{\varepsilon} \nu \mu \circ \varphi \varphi \hat{n} .158$

As Origen did, Proclus also speaks of one single immortal body of each soul, which can be transformed into heavy and earthly by accretion of "tunics"like Origen's Biblical "skin tunics" and Porphyry's "skin tunic"159—upon it, as he makes clear in the Elements of Theology 209 (which relates to the Elements of Theology 196):

The vehicle $\left({ }^{\prime \prime} \chi \eta \mu \alpha\right)$ of every partial soul descends by way of addition of

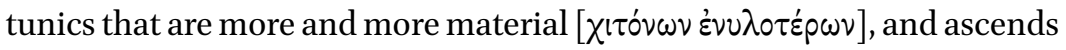
together with the soul thanks to the removal of all that is material and to the return to the form that is proper to it, analogously to the soul that uses it. The soul too, indeed, descends by receiving irrational forms of life, while it ascends by dropping off all the powers that activate the process of generation, which the soul had put on during the descent. [...] Since souls, by their very existence, vivify their vehicles, and the latter are created

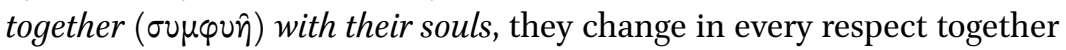

$15^{8}$ Proclus, De sacr. et magia, ap. Psellos, Scripta minora 1.150.13-14.

159 Porphyry, who knew Origen's work, used the same notion of skin tunic in De abstinentia 2.46: "In the Father's temple, i.e. this world, is it not prudent to keep pure our last garment, the skin tunic, and thus, with this tunic made pure, live in the Father's temple?" and 1.31: "We must remove these many garments, both this visible garment of flesh and those inside, which are close to those of skin". Origen maintained that "initially the soul used the luminous ( $\alpha \dot{\gamma} \gamma 0 \varepsilon เ \delta \varepsilon \hat{\imath})$ body as a vehicle ( $(\dot{\pi} \pi \circ \chi \varepsilon \hat{\imath} \sigma \theta \alpha \mathrm{l})$, and this body was later clothed in the skin tunics" (Procopius, Comm. in Gen. 3:21, PG 87/1.221A). See also my Ramelli $2014 f$. 
with the activities of the souls, and follow them everywhere: when the souls experience passions, their vehicles suffer the same with them; once the souls have been purified, their vehicles are restored together with them

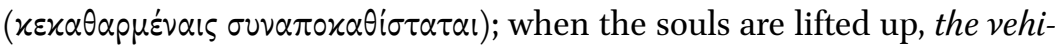
cles rise with them, desiring their own perfection. For every being attains perfection when it reaches its own fullness.

That the perennial body-vehicle is "created together with its soul" is what Origen maintained, but not what Plotinus and virtually all 'pagan' Neoplatonists thought. Even Proclus' notion of a common restoration of soul and body after a period of purification, which is clear in this passage, is identical to that of Origen (which will be taken over by Evagrius). ${ }^{160}$ The same notion that purification must precede apokatastasis to the divine world is reflected in In Rempublicam 1.120.14 in reference to Heracles, who after being purified obtained "the perfect restoration/apokatastasis to the deities."161

Apokatastasis is perfect when it crowns a philosophical life; therefore, in In Timaeum 3.291.32-292.2 Proclus, referring to Plato's Phaedrus, draws a distinction between non-philosophical souls, who can ascend to their own heavenly body within one period, and philosophical souls, who are restored to the intelligible realm after three periods. ${ }^{162}$ If souls attain a restoration without having lived a philosophical life, this restoration is not perfect since they cannot rise to the intelligible realm. ${ }^{163}$ The perfect restoration of the soul is noetic (In Timaeum 2.248.20), ${ }^{164}$ as Origen, Gregory of Nyssa, and Evagrius also main-

\footnotetext{
16o See Ramelli 2017d.

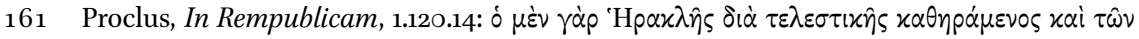

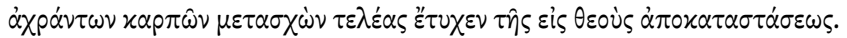

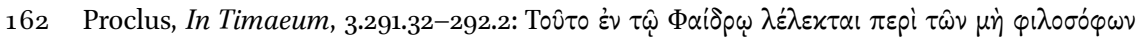

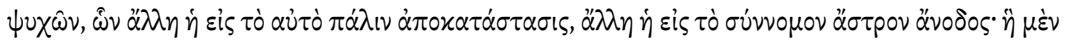

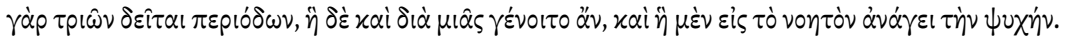

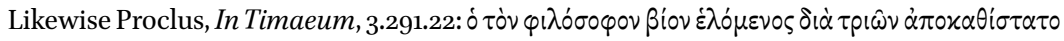
$\beta i \omega \nu$ (with reference to Phaedrus 249AB). For a soul's restoration to its heavenly body see

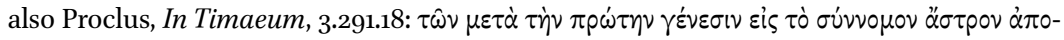

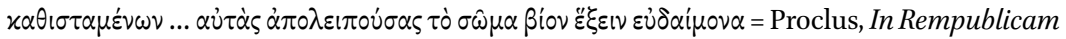

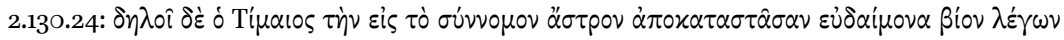

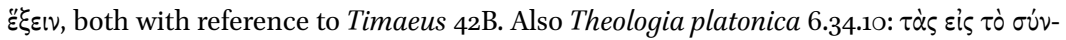

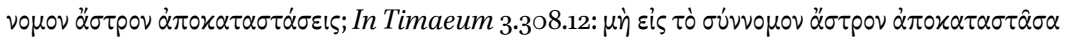

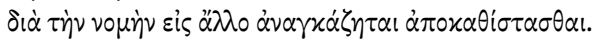

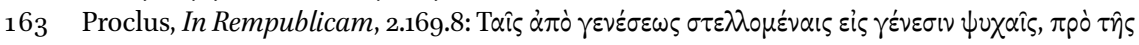

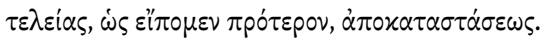

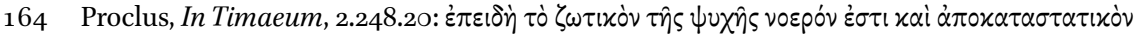

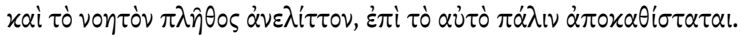


tained. The last systematized a scheme of a threefold resurrection-restoration: that of the body to immortal life, that of the soul to apatheia, and that of the nous to knowledge (Kephalaia Gnostica 5.19; 5.22; 5.25).

Following Syrianus, as it seems, Proclus postulated the existence of two oxy'$\mu \alpha \tau \alpha$ of the soul, not only in the Elements of Theology 196 and 207-209, analysed above, but also in In Timaeum 3.236 and 3.297-298. ${ }^{165}$ The first and loftier bodily vehicle is, as pointed out, immortal, immaterial, simple, and not liable to

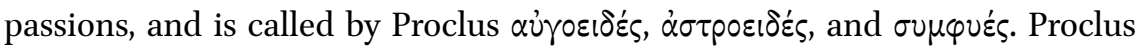
identifies this vehicle with the vehicle in which the Demiurge places the soul according to Plato, Timaeus $4 \mathrm{E}$. The inferior, and subsequent, vehicle of the soul is called by Proclus $\pi v \varepsilon u \mu \alpha \tau i x o v$ and is composed by the four elements, on the basis of Timaeus ${ }_{42} \mathrm{~B} .{ }^{166}$ It is not the vehicle of the rational soul - which is rather the first, luminous body - but the vehicle of the inferior, irrational soul. As such, even if it survives the death of the mortal, heavy and earthly body, it is doomed to disappear.

In his commentary on Timaeus 3.297.21-298.2, Proclus distinguishes the first, immortal vehicle of the soul, the "connate vehicle" ( $\sigma \dot{v} \mu \varphi v \tau o v$ o" $\chi \eta \mu \alpha)$, from a

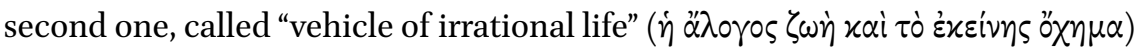

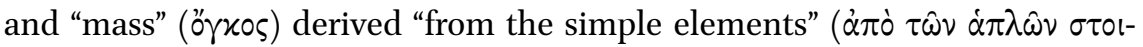

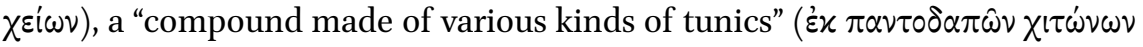

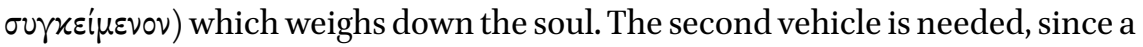

165 Proclus's doctrine of the two oxฑ่ $\mu \alpha \tau \alpha$ will be taken over by Philoponus (De anima 12-14 Hayduck) and probably by Macrobius (In Somnium Scipionis 1.12.13), who speaks of a luminosi corporis amictus, and who ascribes the doctrine of universal apokatastasis to Plato, as pointed out above. Macrobius too was acquainted with the doctrine of apokatastasis of some Christian Platonists. In the passage cited, and in 1.11.12, Macrobius states that the soul, descending through the planetary spheres, acquires a body that is sidereum and lumi-

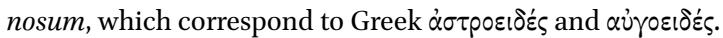

166 Proclus, like Origen and most Platonists, rejected the Aristotelian "fifth body" or "element" (In Timaeum 2.42.9 ff.); in Theologia platonica 1.19.51, when he says that they are "immaterial," he uses $\alpha \ddot{u} \lambda \lambda_{0}$ in the same relative sense as Origen often uses it, not meaning without matter or body in an absolute sense, but as compared with heavy, earthly bodies (for the relativity of such terms in Origen, see Ramelli 2018b). In Cels. 4.56 Origen remarked that Aristotle and the Peripatetics "maintain that aether is immaterial, and is of a fifth substance besides that of the other four elements; against this theory the Platonists and the Stoics adduced noteworthy arguments". Similarly, in C.Io. 13.266 Origen accepted the four elements. Origen's rejection of the fifth element was in line with that of some Middle and Neoplatonists. Atticus, for instance, in fr. 5 Des Places criticised Aristotle for deviating from Plato, who admitted of only four elements. Plotinus certainly rejected the fifth element, as is clear from Enneads 2.1.2, and Porphyry hammered home that Plato's doctrine contemplated only four elements, and that the doctrine of the fifth element is alien to Plato's teaching (ap. Philoponus, De aeternitate mundi, p. 521-522). 
soul could not pass immediately from immaterial pneuma to the earthly body

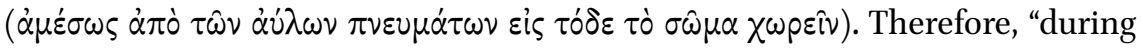
their descent to earth souls receive, one after the other, different kinds of tunics $(\chi i \tau \hat{\omega} \nu \alpha \varsigma)$ made of the elements, air, water, and earth, and only afterwards, in the

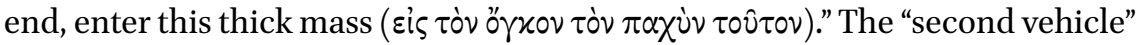
( $\tau$ ò $\delta \varepsilon \dot{\tau} \tau \varepsilon \rho \nu ~ o ̈ \chi \eta \mu \alpha)$ appears again at In Timaeum 3.330.20-22, where it is iden-

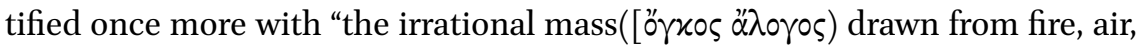
water, and earth."167

In his exegesis of the myth of Plato's Phaedo, where those who dwell in the high places of the earth are mentioned, Proclus interprets them as a reference to souls still linked to this inferior, second vehicle, who are awaiting their complete restoration $(\dot{\alpha} \pi \circ \kappa \alpha \tau \dot{\alpha} \sigma \tau \alpha \sigma \varsigma) .{ }^{168}$ This restoration will liberate them from the second vehicle, but not from the first, which is permanently attached to the rational soul. The last point was maintained by Origen as well. Both at the beginning, at their creation, and at the end, at apokatastasis, rational souls or intellects are joined with a luminous, immortal, and spiritual vehicle.

The theory that the soul is permanently united to a body, from the very beginning, not only is common to both Proclus and Origen, but it seems to have been supported by some other Platonists: according to Iamblichus, "the followers of Eratosthenes and Ptolemy the Platonist, and others" also thought that the soul is always joined to a body and before having an earthly body had "subtler" bodies $(\lambda \varepsilon \pi \tau \dot{\tau} \tau \varepsilon \rho \alpha){ }^{169}$ Did these thinkers maintain that each soul has one body, which by accretion can become heavier (as Origen and Proclus supposed) or that it has different bodies, of different kinds? This is not totally clear.

In any case, Proclus, like Origen and Gregory of Nyssa, ${ }^{170}$ and unlike Plotinus, seems to refuse to admit that human souls can ever exist without a body, thus denying that souls preexist their bodies and receive a body only as a result of a fault. On the other hand, unlike Iamblichus, but like Origen, Gregory of Nyssa and Evagrius, Proclus did not admit that the inferior, irrational faculties of the soul are immortal. ${ }^{171}$ Only the noetic soul is immortal. Evagrius even thought of a subsumption of the body into the soul and of the soul into the nous - a theory that Eriugena traced back to Gregory of Nyssa. ${ }^{172}$

\footnotetext{
167 See Finamore 2021.

168 Proclus, In Timaeum, 3.309.26.

169 Ap. Stobaeus, Anthologium 1.378: 904 Hense.

170 See Ramelli 2021.

171 For the immortality of the rational soul but the disappearance of the irrational parts or faculties at apokatastasis according to Gregory Nyssen see Ramelli $2018 \mathrm{~h}$.

172 Ramelli $2018 \mathrm{~h}$.
} 
If Proclus postulated a permanent first body, this is because-partially unlike Plotinus-he regarded the body and matter as no evil. The identification of God with the One and the supreme Good brings about a metaphysical monism in which evil has no ontological consistence. This was already so in Syrianus (In Metaphysica 8.26.185.19 ff.), this is so in Proclus, and was already a tenet of Origen's anti-Gnostic metaphysics, although Proclus did not acknowledge that Origen identified God with the One (Monad and Henad) and thought that he stopped at the level of the Nous, as seen above.

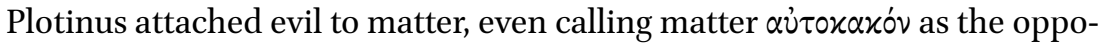
site of $\alpha \dot{v} \tau o \alpha \gamma \alpha \theta 0^{173}$ and claiming that it cannot share in the Good even minimally (Enneads 1.8.5.9). Proclus, instead, like Origen, refused to identify matter with evil. Origen also had a Christian motivation for this: matter is a creature of God and as such it must be good. ${ }^{174}$ Proclus, although he did not support creatio ex nihilo, argued like Origen: given that matter is ultimately produced by the Good, it cannot be evil. ${ }^{175}$ Proclus admits that matter cannot be a good in the absolute sense, $\dot{\alpha} \pi \lambda \hat{\omega} \varsigma \dot{\alpha} \gamma \alpha \theta \dot{o} v,{ }^{176}$ but at least it is "a good of some sort."177 Proclus overtly polemicises with Plotinus when he rules out that matter can be described as the primary evil or absolutely evil:

If matter is necessary to the universe, and the world, this absolutely great and blessed god could not exist without matter, how could one still attach the nature of evil to matter? ... Evil is privation of being. If matter offers itself to be used in the fabrication of the whole world, and has been produced primarily for the sake of being a receptacle of generation, a kind of wet nurse and mother, how can it still be called evil, and even the primary evil? (De malorum subsistentia 32.1-9)

But a similar argument was put forward well before Plotinus, by Plutarch. ${ }^{178}$ The definition of evil as privation of being and its ontological non-subsistence, maintained by Proclus in the block quotation above, was a conviction shared by Origen and most Platonists. Proclus rejects the idea of absolute evil as a principle opposed to the absolute Good because of his strict monism, which

\footnotetext{
173 Enneads 1.8.3.39-40, 8.42, 13.9.

174 Investigation in Ramelli 2012c; Ramelli $2013 \mathrm{f}$.

175 On this argument see Chlup 2012, p. 204 and 207.

176 Proclus, De malorum subsistentia, p. 36-37.

177 Proclus, In Timaeum, 1.385.15.

178 Plutarch, De animae procreatione in Timaeo $1015 \mathrm{DE}$.
} 
he shares with Origen (who used his monism against Gnostic and Marcionite dualistic tendencies, and whose monism was later used by Augustine, another Christian Platonist, at least initially, against the Manichaeans). ${ }^{179}$ According to Proclus, just as to Origen, evil has no ontological consistence; it does not exist from the universal point of view, but only from a fragmented and particular perspective. ${ }^{180}$ This is why Proclus calls its existence "parasitic" ( $\pi \alpha p v \pi \delta$ o $\tau \alpha \sigma \iota \zeta$, $\pi \alpha p \cup \varphi i \sigma \tau \alpha \sigma \theta \alpha \mathrm{l}$, De malorum subsistentia $7 ; 49^{-50}$ ) and maintains that evil is never pure, never "unmixed, but it is evil in one respect [sc. from the partial perspective] and good in another [sc. from the perspective of the whole], and insofar as it is good, it is from the gods, but insofar as it is evil, it is from another, powerless, source" (De malorum subsistentia 42 ). ${ }^{181}$

Like Origen, Proclus thinks that the individual soul causes evil not primarily, because evil cannot follow from its very nature, which is good, and if it proceeds from its will, it is because of a wrong and misled choice (De malorum subsistentia 46). The cause of evil is the soul's weakness (ibid. 48). Ethical intellectualism, a Socratic-Platonic and Stoic tenet, seems to be still at work here: nobody voluntarily chooses evil qua evil, but because one mistakes it for a lesser good. ${ }^{182}$ Like Origen, Proclus too thinks that evil derives from a falling short of one's own nature, lacking one's proper virtue (De malorum subsistentia 25). Indeed, both body and soul share in evil when they are in a state of disharmony (In Rempublicam 1.38.9-15), that is, injustice, which already Plato connected with evil, insofar as it is committing injustice and not suffering it (Gorgias 469AB). But "as soon as evils arise in their parasitic form, the whole uses them for its own purposes [...] and makes them good" (In Rempublicam 1.38.25-26). Proclus' theory of evil in De malorum subsistentia famously influenced Dionysius and had a huge impact on later Christian thought, but Proclus' treatment still needs to be systematically compared to earlier Platonic thought (including at least the Christian Platonism of Origen).

179 On Origen, see Ramelli 2013c, the chapter on Origen, and on Augustine Ramelli 2013a; further work is ongoing.

180 Proclus, De malorum subsistentia, 27.3-19; Proclus, In Timaeum, 1.380.26-27.

181 Opsomer 2001, p. 183.

182 Preliminary reflections in Ramelli forthcoming- i. Further investigation is needed into the reception of, or reaction to, ethical intellectualism in patristic thought. 


\section{Resurrection, Restoration, and the Main Difference between Proclus and Origen}

Of course, Proclus, as a "pagan" Platonist, did not theorise a resurrection of the body together with the restoration of the soul, unlike Origen and his follower Gregory of Nyssa. However, the resurrection conceived by Origen and Nyssen was a resurrection of the spiritual body of the beginning of a rational creature's substantial creation (light, luminous, immortal, impassible etc.). This notion comes remarkably close to Proclus' idea of the apokatastatic return to the first body, the spiritual body that accompanies the rational soul from the beginning of the substantial creation of a rational creature. Evagrius, a close follower of Origen and Nyssen, ${ }^{183}$ as seen, on the basis of Nyssen even envisaged a final subsumption of the body into the soul, and of the latter into nous (and, in theosis, of the nous into God). Thus, in this respect there is not an abysmal difference between the two sides.

Rather, the principal divergence between Proclus and those Christian Neoplatonists is the infinity of the apokatastatic cycles that Proclus maintains in conformity with the theory of the perpetuity of the world. Origen and Gregory of Nyssa, instead, taking for granted that this world was created in time, also thought that it will have an end in time. Their motivation was not only the perishability axiom, well known to all Platonists, as mentioned (but applied also by Basil, for instance, to the world), but also Scripture, which speaks of the end of the world. Thus, already Origen made this a tenet of his philosophy of history and doctrine of apokatastasis. Consequently, Origen, like Gregory after him, thought that there is a cyclical succession of aeons, but this succession is finite, and it will have an end exactly with the eventual apokatastasis. This restoration, at the end of all aeons, that is, at the end of time, will occur only once, and not infinite times, as Proclus seems to postulate. This seems to constitute the main differentiation between Proclus and these Christian Neoplatonists.

As indicated earlier, Plato in Phaedrus 248CE suggested that, if a soul can attain a vision of the Forms, it will be released from incarnation for a cycle of ten thousand years, just as a soul that chooses the life of the philosopher for three subsequent periods of one thousand years. Proclus himself glosses the Phaedrus passage as a reference to the apokatastasis of the soul from the realm of generation and becoming ${ }^{184}$ to the intelligible world (although this

183 As I hope to have argued thoroughly in Ramelli $2015 \mathrm{C}$ and Ramelli $2017 \mathrm{~d}$.

184 The passage "from generation to generation before the perfect restoration" is associated by

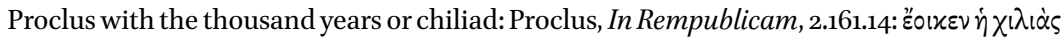

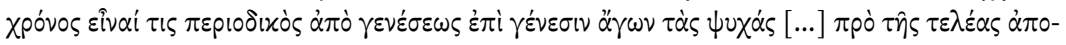




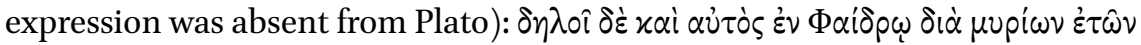

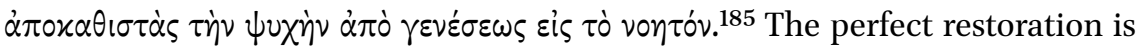
indeed the attainment of "the knowledge of all" or $\gamma \nu \omega \hat{\omega} \iota \varsigma \pi \alpha \dot{\nu} \tau \omega \nu$ (In Rempublicam 2.168.16). ${ }^{186}$ Again in In Rempublicam 1.175.26 Proclus refers to the same Platonic passage when he states that "souls, after being bridled for nine thousand years on earth, are restored at the tenth thousand year" ( $\dot{\varepsilon} v v \varepsilon \dot{\varepsilon} \alpha \chi \lambda \lambda_{1} \dot{\alpha} \delta \alpha \varsigma$

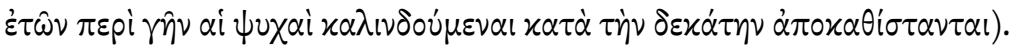

Only in one passage (reflecting some ambiguity already present in Plato) does Proclus suggest that the restoration after ten thousand years may be definitive: in In Rempublicam 2.170.27 he says that after such a restoration there is no other biological life, because the myriad is the limit of all generations. ${ }^{187}$ This, though, may also mean that there is no other biological life during that myriad, but there can be others in the following myriads. Not all souls, according to Proclus, can attain restoration to the intelligible realm: the less rational among them either are not restored at all to the intelligible realm, or they are restored to it only with great difficulty, or as the latest of all. ${ }^{188}$

Within "pagan" Neoplatonism, Plotinus seems to have postulated no release for the soul from the cycles of incarnation, and therefore infinite restorations to the intelligible world at the end of each cycle. Porphyry in De regressu animae, at least as reported by Augustine De civitate Dei 10.30; 12.27, claimed that the soul of the philosopher alone will finally be released forever. The soul, "once purified from all evils and established with the Father, will never again endure the evils of this world" (Regr. fr. 11). Therefore, the soul's return or restoration will be definitive and eternal, as in the theory of Origen. For Origen, all intellectual creatures will be restored (whereas the issue of universalism remains problematic in the case of Porphyry ${ }^{189}$ ), and there will be no new fall after the eventual apokatastasis. The restoration of the soul will not be temporary in the

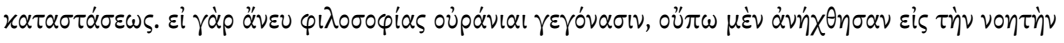

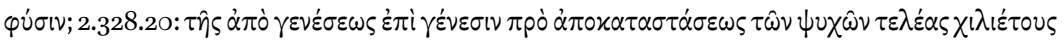

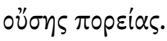

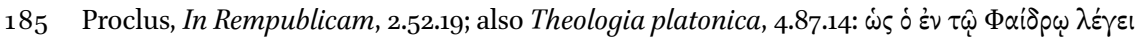

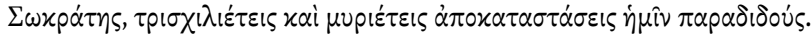

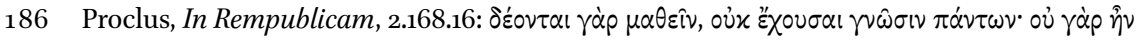

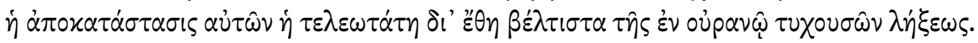

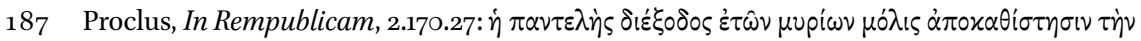

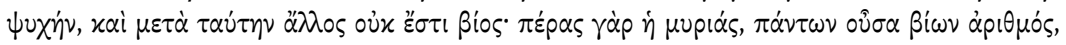

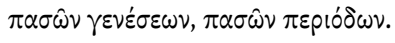

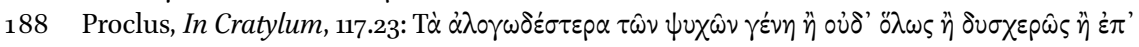

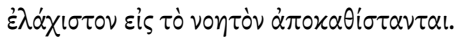

189 See above; Simmons 2015 and Ramelli forthcoming- $d$. 
framework of infinite cycles of restoration always followed by new falls into the realm of becoming.

The latter view was supported by Secundus Sallustius in De diis et mundo 20 , on the basis of the natural affinity of the soul for a body and of the limited number of souls, which must necessarily be reincarnated without end, given the eternity of the world. ${ }^{190}$ Proclus appears to be on the same line. He argues that, according to the cosmic law, each soul must become incarnate at least once in each cosmic cycle (In Timaeum 3.278.10), even though in In Cratylum 117 he makes an exception for souls such as that of Heracles, who may skip several cosmic cycles. Even in this case, however, the soul must continue to descend at least some times. In such cases, the descent is not a result of sin, but it is rather the effect of the generosity of a soul that wants to assist lesser souls in the process of salvation: "to do good to less perfect souls, out of providence for those

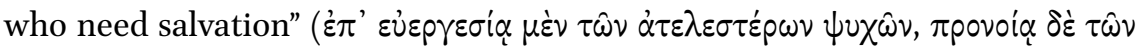

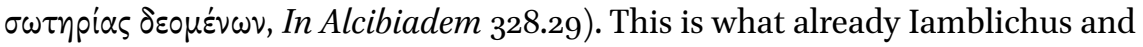
Origen admitted: some souls descend not because of sins of their own, but to assist divine providence.

According to Proclus, the cyclic periods of particular souls are infinite, and therefore their restorations also occur infinite times. This is clear from the Elements of Theology 206 as well, where Proclus also has recourse to the perishability axiom:

Every particular soul can descend into generation and ascend again from generation to being infinite times ( $\left.\dot{\varepsilon}^{\prime} \pi^{\prime} \ddot{\alpha} \pi \varepsilon ı \rho \nu\right)[\ldots]$ for what had no beginning in time will have no end either, and what has no end necessarily has no beginning. The consequence is that each soul makes ascents from generation and descents into generation, and this has no end ( $\alpha$ $\pi \alpha v \sigma \tau 0 \nu)$

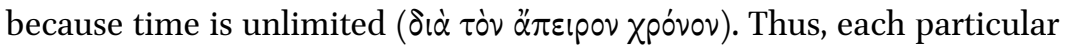
soul can descend and ascend infinite times, and this will never stop happening to every soul.

Within the field of philosophy of history, Proclus' notion of an infinity of apokatastaseis instead of one single apokatastasis at the end of time appears to constitute the main divergence between Proclus' doctrine of apokatastasis and that of the Christian Neoplatonists. But the convergencies are also impor-

190 With regard to the most perfect souls, Sallustius says that, separated from the irrational soul and pure, they will dwell with the gods (De diis et mundo 21), but not that they will do so forever. 
tant and, given Proclus' knowledge of Origen, one cannot rule out a possible influence of Origen's doctrine upon that of Proclus.

In the fifth century, Hierocles of Alexandria, like Proclus, explicitly mentioned and praised "Origen" (again, only indicated by his name and as a disciple of Ammonius Saccas, without any distinction between a Christian and a Platonist Origen). Hierocles styles Origen and Plotinus as Ammonius' most illustrious disciples (following Photius, Bibliotheca cod. 214.172b). That Plotinus and Origen were the best of all those who attended Ammonius' school is even repeated by Hierocles (Photius, Bibliotheca 251.461b). This is why Hierocles mentions Origen among the most important Neoplatonists, who followed Plato's "purified" thought, immediately after Plotinus and as a contemporary of his (Photius, Bibliotheca 214.172b). Hierocles may have known Origen's doctrine of apokatastasis.

Hierocles' two loci concerning apokatastasis bear remarkable similarities to Origen's theory of apokatastasis; in this light, some direct or indirect influence cannot be totally excluded. In In aureum carmen 20.5, Hierocles identifies the apokatastasis of human beings with their deification, exactly like Origen, and, like him, explains that it can be reached by means of virtue and knowl-

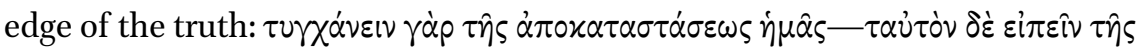

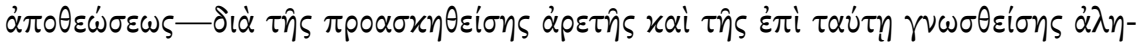
$\theta$ cias (these points will be developed by Evagrius in his own apokatastasis doctrine). ${ }^{191}$ The ascetic exercise of the soul in view of virtue, Hierocles adds, is

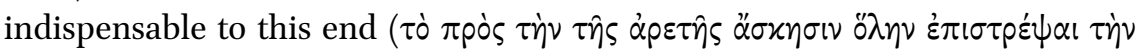
$\psi v \times \dot{\eta} \nu)$, as Evagrius also maintained with his bipartition of $\pi \rho \alpha \kappa \tau i x \dot{\eta}$ and $\theta \varepsilon \omega-$ pi $\alpha$, which in turn has roots in Neoplatonic theories. ${ }^{192}$ Then, in 27.2-3 Hierocles links the requirement of virtue in the soul with that of purity in its "pneumatic

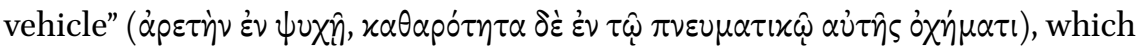
reminds us of Origen's spiritual body and of Proclus' primal body. In this way one can become "entirely healthy" and thus "be restored to the form of one's

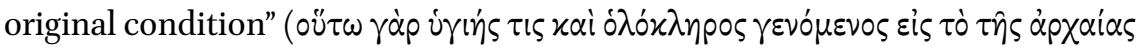

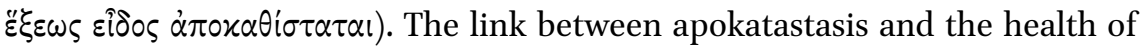
the soul is as old as Philo at least, ${ }^{193}$ and was kept by Origen and his followers, including Evagrius himself.

191 On the presence of exactly these characteristics of apokatastasis in Origen and Evagrius see Ramelli 2013a, chapters on Origen and Evagrius. For Origen, the connection between apokatastasis and theosis is further explored in a monograph in the works, ch. 2.

192 See Ramelli 2014e.

193 Argument in Ramelli 2014g. 
Hierocles describes again here apokatastasis as deification, like Origen ( $\tau$ ò

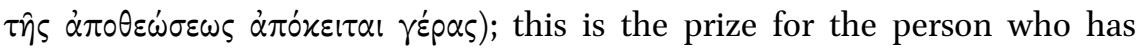
acquired virtue and the knowledge of the truth in his or her soul and purity in his or her pneumatic vehicle-note that Origen also conceived of likeness/assimilation to God and consequent deification as the reward of one's personal moral effort (in what I call his "theology of freedom," which was taken over by Nyssen as well). According to Hierocles, deification entails union

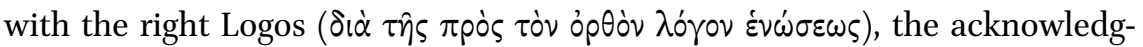

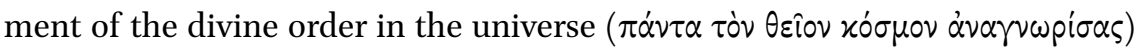

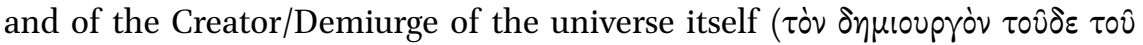
$\pi \alpha \nu \tau \dot{c} \varsigma \xi \xi \xi \varepsilon u p \omega \omega v)$. After acquiring this knowledge, following the due purification ( $\mu \varepsilon \tau \dot{\alpha} \tau \dot{\eta} \nu \varkappa \dot{\alpha} \theta \alpha \rho \sigma \nu)$-according to the Platonic purification-knowledge scheme, embraced by Origen, Gregory of Nyssa and Evagrius as well ${ }^{194}$ - one will be restored to the state that is always enjoyed by those beings who by

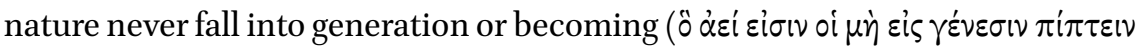
$\pi \varepsilon \varphi \cup x o ́ \tau \varepsilon \varsigma$ ), will be united to the universe thanks to knowledge ( $\tau \alpha \hat{\imath} \varsigma \mu \dot{\varepsilon} \nu ~ \gamma \nu \omega \dot{\sigma \varepsilon}$ -

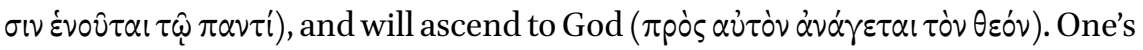

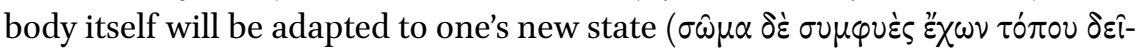

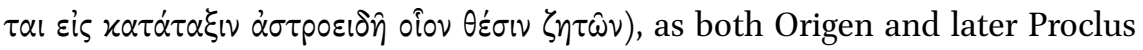
maintained. ${ }^{195}$

God $\pi \dot{\alpha} \nu \tau \alpha \dot{\varepsilon} \nu \pi \hat{\alpha} \sigma \nu \nu$ in Origen, His Followers, and Proclus' Elements of Theology

A pivotal — although so far rather neglected — point related to theology, metaphysics, and the doctrine of apokatastasis is shared by Proclus, Origen, Gregory of Nyssa, Iamblichus, and Dionysius: the notion that the divinity is "all in all" ( $\pi \dot{\alpha} v \tau \alpha \dot{\varepsilon} \nu \pi \hat{\alpha} \sigma \nu$, the expression common to all of these Neoplatonists) but in a

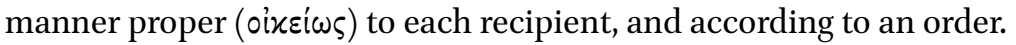

Origen seems to be the first Platonist in which this principle emerges and is used everywhere. Its declared foundation, according to Origen, is Biblical, in 1 Cor 15:28: here, Paul depicts the perfection of the telos as the state in which God is "all in all," $\tau \dot{\alpha} \pi \dot{\alpha} \nu \tau \alpha \dot{\varepsilon} \nu \pi \hat{\alpha} \sigma \nu$. Origen elaborated a great deal on this notion, making it the cornerstone of his protology, Christology, metaphysics, and doctrine of apokatastasis (in Paul, too, it was an eschatological tenet). ${ }^{196}$

194 Stefaniw 2010; Ramelli 2017d.

195 Documentation in Ramelli 2018b.

196 Analysis in Ramelli 2007b. 
In his commentary on 1 Cor 15:24-28, In illud: tunc et Ipse Filius, and elsewhere, Nyssen deepened Origen's thought in this respect — as in many others-

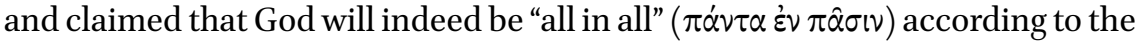
capacity of each recipient and in a precise order, depending on the degree of each one's adhesion to the Good. As Gregory explains in In illud, describing the triumphal march of the Good (God), who, in the end, will gain all to itself, those who are farthest removed from the Good will be the last to be restored to God-the Good. ${ }^{197}$ One can even suppose that Plotinus criticised Origen's doctrine, which he knew, when in Enneads 6.5.3.13-15 he claimed that the divinity, or the highest principle, far from being "in all," "is itself in nothing, but it is the other beings that participate in it, all those which can be present to it and insofar as they can be present to it." This is a criticism of the tenet that God is "all in all," although Origen himself was keen on explaining that Christ, qua God and the world of Ideas (including Virtue Forms), does not participate in everything but - as Plotinus' first principle - is rather participated by all creatures who share in a given virtue. Thus, for example, Christ is Justice itself, the Platonic Idea of Justice, and all the just participate in Christ, according to the Platonic category of $\mu \dot{\varepsilon} \theta \varepsilon \xi$ เ५ (Cels. 6.64). Plotinus' explanation of cathartic virtues is likewise based on the Platonic participation model: the cathartically

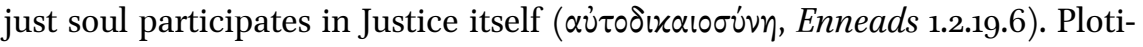
nus may have regarded the idea of God "all in all" as contravening the Platonic scheme of participation.

The notion of the presence of God "all in all" is found again in Neoplatonism, after Origen, on the "pagan" side. However, the context is different (at least before Proclus): it is the presence of all in all (an Anaxagorean principle), without mention of God or the highest Principle. Indeed, Proclus alone will develop the same formula as Origen did: that of God "all in all." Porphyry, who was well acquainted with Origen's work, has the (Anaxagorean) formulation without God, with the reference to "appropriateness" which will appear again in Proclus:

All is in all, but in an appropriate way (oixei $\omega \varsigma$ ) according to the essence of each thing: in the intellect in an intellectual way, in the (rational) soul in a rational way, in plants in a seminal way, in bodies in the form of images, and in what is beyond (intellect and being) in a super-intellectual and a super-essential way. (Sent. ad intell. 10)

197 Thorough analysis in Ramelli 2007b; further 2018a. 
Yet, Iamblichus declares that Porphyry rejected this principle of "all in all" elsewhere. ${ }^{198}$ Iamblichus did use this tenet, ${ }^{199}$ and attributed it to Numenius, ${ }^{200}$ a Middle-Platonist / Neopythagorean who was very well known to Origen. But Origen formulated this principle not in an Anaxagorean way, but in reference to God or the supreme $\dot{\alpha} p \times \dot{\eta}$, as Proclus later did.

Proclus took over both Origen's formulation of the "all in all" principle and that of Porphyry, Numenius, and Iamblichus. He frequently appealed to this tenet. Actually, the first proposition of his Elements of Theology states that God, the One, is in all, in that all multiplicity somehow participates in the One. In the Elements of Theology 23 he stresses that the first principle is "in all" ( $\dot{\varepsilon} v \pi \hat{\alpha} \sigma$ iv $\dot{\varepsilon} \sigma \tau \iota)$, but also voices the concern that it is not immanent, but transcendent. In

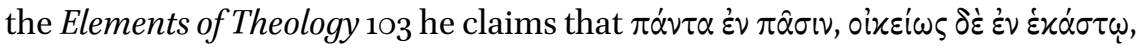
"all things are in all, but in each one in an appropriate manner" - the same formulation as in Porphyry's Sentences examined above.

Dionysius, a Christian Neoplatonist who was inspired by both Origen and Proclus, took over the principle both in Origen's and in Proclus' formulation. Proclus' formulation, without reference to God, emerges in the Divine Names

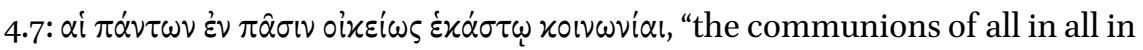
a manner appropriate to each one." Origen's and Proclus' formula, referring to the first principle as in Origen, appears in the Divine Names 1.7.596c-597a:

The Cause of All is "all in all ( $\pi \dot{\alpha} \nu \tau \alpha \dot{\varepsilon} \nu \pi \hat{\alpha} \sigma \mathrm{l})$ " according to the saying [Pauline, Origenian, or Procline?], and certainly it must be praised in that it is the Giver of existence to all, the Originator of all beings, who brings all to perfection, holding them together and protecting them; their seat,

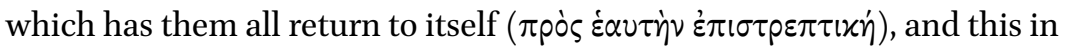
a unified, irresistible, absolute, and transcendent way.

Dionysius acknowledges the formula, both Biblical and philosophical, and calls it "saying," $\lambda$ ó $10 \mathrm{v}$, also meaning "divine utterance / oracle." It has both Proclus' metaphysical import and Origen's eschatological value, which Dionysius expresses in Proclean terms of reversion ( $\dot{\varepsilon} \pi \sigma \tau \rho \circ \varphi \eta \eta)$. The formula appears again in the Divine Names 11.5, p. 221 Suchla, in which Dionysius is speaking of the contents of his lost treatise, Outlines of Theology; here the formula is referred to Jesus qua God and his operations, and has both metaphysical and eschatological overtones: "What could be said of Christ's love for humanity, a

\footnotetext{
198 Ap. Stobaeus, Ecl. 1.49.31, p. 866 Hense.

199 Ap. Proclus, In Timaeum 1.426.20.

200 Ap. Stobaeus, Ecl. 1.49.31, p. 866 Hense.
} 
love that gives peace in profusion? Jesus who operates all in all ( $\tau \dot{\alpha} \pi \dot{\alpha} \nu \tau \alpha \dot{\varepsilon} \nu \pi \hat{\alpha} \sigma \mathrm{l}$

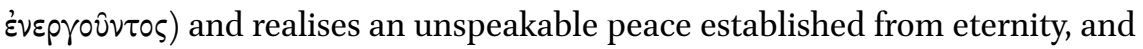
reconciles us to him in spirit, and, through himself and in himself, to the Father. Of these wonderful gifts I have abundantly and sufficiently spoken in the Theological Outlines, where to our testimony is joined that of the holy inspiration of Scriptures / of the sages / of the sayings / oracles ( $\lambda \circ \gamma^{\prime}(\omega \nu) . "$

In the Divine Names 9.5 Dionysius obviously follows Origen's formulation and relates the situation described by 1 Cor 15:28, God as "all in all," both to "the providence of God" and to "the salvation/preservation of all beings," which can bear both a historical and an eschatological meaning. He states that "in his providence, God is close to every being," continually assisting each of them until the end, "and (thus) becomes 'all in all." The reason for this is $\delta \dot{\alpha} \tau \tau \dot{\eta} \nu \pi \alpha \dot{\nu}$ $\tau \omega \nu \sigma \omega \tau \eta{ }^{\prime} \alpha \nu$, which can mean both the preservation of all beings now and their eventual salvation.

Gregory of Nyssa had also joined both Origen's eschatological formulation that God will be all in all, and the non-eschatological formula in An. et res. 132: "The power of the Spirit, which operates all in all/all things/all beings" ( $\tau \dot{\eta} \nu \tau \dot{\alpha}$

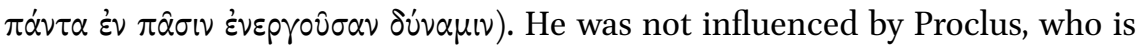
posterior, but certainly by Origen. Maximus, after both Proclus and Dionysius (and familiar with both), took over only Origen's theological and eschatological formulation, once again within the eschatological framework of apokatastasis (and interpreting God's final being "all in all" in the same way as Origen had done):

God will truly come to be "all in all," embracing all, and giving substance to all in Godself, in that no being will have any more a movement independent of God, and no being will be deprived of God's presence. Thanks to this presence, we shall be, and shall be called, gods and children, body and limbs, because we shall be restored to the perfection of God's project (Ambigua 7.1092Cff.).

\section{$7 \quad$ Concluding Reflections and Indications for Further Research}

Proclus' theory of apokatastasis and reversion, related to his Noetic Triad and to the idea of God being "all in all," displays remarkable convergencies with that of Origen. Many significant points of contact, which I have pointed out, together with Proclus' knowledge and appreciation of "Origen" and the extraordinary rate of occurrence of the very lexicon of $\dot{\alpha} \pi 0 x \alpha \tau \dot{\alpha} \sigma \tau \alpha \sigma \iota \zeta$ in Proclus' oeuvre (against the scanty or inexistent occurrences and the apparent lack of interest 
in this doctrine generally shown by previous "pagan" Platonists) certainly raises at least the suspicion that Proclus worked out his own doctrine of apokatastasis and $\dot{\varepsilon} \pi \sigma \tau \tau_{0} \varphi \eta$ ' with Origen's theory at the back of his mind, or possibly the reformulations of Origen's theory in later Christian Neoplatonism, especially in Gregory of Nyssa and Evagrius Ponticus.

Proclus' notion of apokatastasis did not rest, as in the case of Origen, on the Christian notion of "the end of the world," but rather presupposed a cosmology of an infinity of cycles of apokatastasis and thereby comes closer to the Stoic (and later 'pagan' Neoplatonic) theory of apokatastasis than to that of Origen and his followers. Of course, Proclus was a Platonist but not a Christian Platonist, so, unlike Origen, he did not feel bound by the Biblical tenet of the "end of the world." But his Elements of Theology, as well as other works such as the Commentary on the Parmenides, seem to have been informed by a good knowledge of Origen's ideas, both in connection with apokatastasis (and the dovetailing of $\dot{\pi} \pi \sigma \tau \rho \circ \varphi \eta$ and apokatastasis, and the concept of God as being "all in all but oix $\left.\varepsilon^{\prime} \omega \varsigma^{\prime}\right)$ and in connection with the "permanent" first body.

If Proclus' Origen, metaphysician and allegoriser of Plato, was the Christian Origen, metaphysician and allegoriser of Plato and Scripture, Proclus valued a Christian Platonist's exegesis of Plato and regarded Origen's 'Ammonian' writings as part of an authoritative Neoplatonist corpus. He probably knew Christian philosophical texts by Origen such as First Principles, Commentary on John — likely known also to Amelius and certainly to Porphyry—and Against Celsus. Proclus, indeed, like Hierocles, refers to doctrines expressed there, not just in Origen's 'Ammonian' treatises. Conversely, Porphyry F39 ascribes Greek doctrines to the Christian Origen in metaphysics and theology: "his ideas were those of a Greek in his view of the existing realities and God ( $x \alpha \tau \dot{\alpha} \tau \dot{\alpha} \varsigma \pi \varepsilon p i \tau \hat{\omega} \nu$

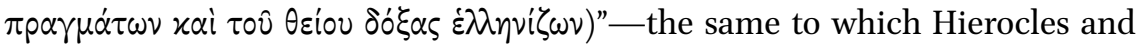
Proclus refer.

Porphyry, Hierocles, and Proclus esteemed Origen as a philosopher, albeit disagreeing on some points, and Porphyry and Proclus seem to have adopted some of Origen's concepts: Porphyry took up Origen's protological notion of hypostasis and attached it to Plotinus, besides being sensitized by Origen to the problem of universalism and probably being influenced by his ideas in a number of other ways. Proclus likely had Origen in mind about apokatastasis, God "all in all," first bodies, and probably other issues. ${ }^{201}$ Significantly, Justinian detested both Origen, with his legacy, and the Neoplatonists of Proclus' Athenian school. Like Hierocles, Proclus received and regarded highly a

201 Ramelli 2012a and a work on Origen, in preparation, Ch. 5 on Porphyry. 
"de-Christianised" Origen whose protology was criticised but taken into consideration, and whose Platonic exegesis was respected. Sergius of Resh'aina too, a disciple of the Neoplatonist Ammonios Hermeiou—Proclus' pupil—was well acquainted with Origen's ideas. ${ }^{202}$

\section{Bibliography}

\section{Manuscripts}

München, Bayerische Staatsbibliothek, Gr. 314.

\section{Primary Sources}

Aristotle, Metaphysica, ed. W. Jaeger, Oxford, Clarendon Press, 1957.

Athanasius De decretis Nicenae synodi, in Athanasius Werke, vol. 2/1, ed. H.G. Optiz, Berlin, de Gruyter, 1940.

Aristoxenus, Harmonica Elementa, in Antiquae musicae auctores septem graece et latine, vol. 1, ed. M. Meibom, Amsterdam, Elzevier, 1652.

Augustine, De civitate Dei (cCsL 47-48), eds B. Dombart, A. Kalb, 2 vols., Turnholt, Brepols, 1955 .

Damascius Olympiodorus In Platonis Phaedonem commentaria, ed. W. Norvin, Leipzig, Teubner, 1913 .

Damascius, Traité des premiers principes, eds L.G. Westerink, J. Combès, 3 vols., Paris, Les Belles Lettres, 1986-1991.

Eusebius Historia Ecclesiastica, ed. and transl. G. Bardy, 3 vols., Sources Chrétiennes 31, 41, 55, Paris, Éditions du Cerf, 1952-1958.

Gregory Thaumaturgus, Remerciement à Origène, ed. H. Crouzel, Paris, Cerf, 1969 .

Iamblichus, Réponse à Porphyre (De mysteriis), ed. and transl. H.-D. Saffrey, A.Ph. Segonds, Paris, Les Belles Lettres, 2013.

Irenaeus of Lyons, Contre les Hérésies, eds J. Rouseeau, H. Doutrelaeau, 10 vols., Paris, Cerf, 1972-1982.

Macrobius, Commentarii in Somnium Scipionis, ed.J. Willis, Stuttgart / Leipzig, Teubner, 1994.

Marinus, Proclus ou Sur le bonheur, ed. and transl. H.D. Saffrey, A.-P. Segonds, Paris, Les Belles Lettres, 2001.

Michael Psellos, De omnifaria doctrina, ed. L.G. Westerink, Utrecht, J.L. Beijers, 1948.

Origen, Against Celsus, transl. H. Chadwick, Cambridge, CuP, 1953.

Origen, Commentaria in Evangelium Iohannis, PG 14, Paris, Migne, 1862, cols. 21-83o.

202 As is also attested by Ps.-Zacharias, Chron. 9.19. 
Origen, De principiis, ed. P. Koetschau, Leipzig, Hinrichs, 1913.

Philoponus, In Aristotelis De anima libros commentaria, ed. M. Hayduck, CAG XV, Berlin, Reimer, 1897.

Philoponus, De aeternitate mundi contra Proclum, ed. H. Rabe, Leipzig, Teubner, 1899; repr. Hildesheim, Olms, 1984.

Photius, Bibliothèque, ed. and transl. R. Henry, 8 vols., Paris, Les Belles Lettres, 19591977.

Plato, Parmenides, in Platonis Opera, vol. 2, ed. J. Burnet, Oxford, Clarendon Press, 1903 .

Plotinus, Plotini Opera, eds P. Henry, H.-R. Schwyzer, 3 vol., Oxford, Clarendon Press, 1964-1982.

Plutarch, On the Generation of the Soul in the Timaeus, in Moralia, vol. XIII, part 1, transl. H. Cherniss, Cambridge, MA, Harvard University Press, 1976.

Plutarch, Isis and Osiris, in Moralia, vol. v, transl. F.C. Babbitt, Cambridge, MA, Harvard University Press, 1936.

Porphyry, Lettre à Anébon l'Égyptien, ed. and transl. H.-D. Saffrey, A.Ph. Segonds, Paris, Les Belles Lettres, 2012.

Porphyry, On Abstinence from Killing Animals, transl. G. Clark, London, Duckworth, 2000.

Proclus, De l'éxistence du mal, in Proclus: Trois études sur la providence, Vol. 3, ed. and transl. D. Isaac, Paris, Les Belles Lettres, 1982.

Proclus, Commentary on Plato's Republic, Volume I, Essays 1-6, transl. D. Baltzly, J.F. Finamore, G. Miles, Cambridge, CUP, 2018.

Proclus, De sacrificiis et magia, ap. Psellos, Scripta minora.

Proclus, Die mittelalterliche Übersetzung der Stoicheiosis phusike des Proclus, ed. H. Boese, Berlin, Akademie Verlag, 1958.

Proclus, In Platonis Parmenidem Commentaria, Tomus I libros I-III continens, eds C. Steel, C. Macé, P. d'Hoine, Oxford, Clarendon Press, 2007.

Proclus, In Platonis Parmenidem Commentaria, Tomus II libros IV-V continens, eds C. Steel, A. Gribomont, P. d'Hoine, Oxford, Clarendon Press, 2008.

Proclus, In Platonis Parmenidem Commentaria, Tomus III libros VI-VII continens, eds C. Steel, L. Van Campe, Oxford, Clarendon Press, 2009.

Proclus, In Platonis Timaeum commentaria, ed. E. Diehl, 3 vols., Leipzig, Teubner, 19031906 (repr. Amsterdam, Hakkert, 1965).

Proclus, Hypotyposis astronomicarum positionum, ed. C. Manitius, Leipzig, Teubner, 1909 (repr. Stuttgart, Teubner, 1974).

Proclus, In primum Euclidis elementorum librum commentarii, ed. G. Friedlein, Leipzig, Teubner, 1873 (repr. Hildesheim, Olms, 1967).

Proclus, In Platonis Cratylum commentaria, ed. G. Pasquali, Leipzig, Teubner, 1908 (repr. Stuttgart, Teubner, 1994). 
Proclus, The Elements of Theology (2nd ed.), ed. E.R. Dodds, Oxford, Clarendon Press, 1963.

Proclus, Théologie platonicienne, ed. and transl. H.D. Saffrey, L.G. Westerink, 6 vol., Paris, Les Belles Lettres, 1968-1997.

Procopius, Commentarius in Genesim, PG 87/1, Paris, Migne, cols. 13-512.

Pseudo-Zacharias, The Chronicle of Pseudo-Zachariah Rhetor: Church and War in Late Antiquity, ed. G. Greatrex and transl. R.R. Phenix, C.B. Horn, Liverpool, Liverpool University Press, 2011.

Sallustius, Concerning the Gods and the Universe, ed. and transl. A.D. Nock, Cambridge, CUP, 1926.

Porphyry, Sententiae ad intelligibilia ducentes, ed. Erich Lamberz, Berlin, De Gruyter, 1975 .

Stobaeus, Ioannis Stobaei anthologii libri duo posteriores, ed. O. Hense, 3 vols., Berlin, Weidmann, 1894-1912.

Stobaeus, Ioannis Stobaei anthologii libri duo priores, qui inscribi solent eclogae physicae et ethicae, ed. C. Wachsmuth, 2 vols., Berlin, Weidmann, 1884.

Stoicorum Veterum Fragmenta, ed. H. von Arnim, Leipzig, Teubner, 1903-1905

Suidae lexicon, ed. A. Adler, Leipzig, Teubner, 1928-1938.

Syrianus, In Metaphysica commentaria, in Commentaria in Aristotelem Graeca, Volume vi, Part i, ed. W. Kroll, Berlin, Reimer, 1902.

\section{Secondary Sources}

Addey, C. (2014), Divination and Theurgy in Neoplatonism, Farnham, Ashgate.

Bäbler, B., Nesselrath, H.-G. (2018), Origenes der Christ und Origenes der Platoniker, Tübingen, Mohr Siebeck.

Baltzly, D. (2017), "The Skopos Assumption: Its Justification and Function in the Neoplatonic Commentaries on Plato", in International Journal of the Platonic Tradition 11, p. 173-195.

Beatrice, P.F. (1992), "Porphyry's judgment on Origen”, in R.J. Daly (ed.), Origeniana Quinta, Leuven, Peeters, p. 351-367.

Beatrice, P.F. (2009), "Origen in Nemesius' treatise On the nature of man", in G. Heidl, R. Somos, in coll. with C. Németh (eds), Origeniana nona, Leuven, Peeters, p. 505532.

Beatrice, P.F. (2019), "Porphyry at Origen's School at Caesarea", in B. Bitton-Ashkelony, O. Irshai, A. Kofsky, H. Newman, L. Perrone (eds), Origeniana Duodecima, Leuven, Peeters, p. 267-284.

Biblia Patristica: Origène (1980), Paris, Editions du Centre national de la Recherche scientifique.

Böhm, T. (2002), "Origenes-Theologe und (Neu-)Platoniker? Oder: Wem soll man mißtrauen-Eusebius oder Porphyrius?", in Adamantius 8, p. 7-23. 
Böhm, T. (2003), "Unbegreiflichkeit Gottes bei Origenes und Unsagbarkeit des Einen bei Plotin”, in L. Perrone (ed.), Origeniana Octava, Leuven, Peeters, p. 451-463.

Böhm, T. (2004), "Denken des Einen: die platonischen Voraussetzungen der 'sethianischen' Gnosis”, in J.-M. Narbonne, A. Reckermann (eds), Pensées de l'Un dans l' histoire de la philosophie. Études en hommage au professeur Werner Beierwaltes, Paris / Laval, Vrin / Presse de l' Université Laval, p. 123-139.

Chiaradonna, R. (2016), "Porphyry and the Aristotelian Tradition", in A. Falcon (ed.), Brill's Companion to the Reception of Aristotle in Antiquity, Leiden, Brill, p. 321340.

Chlup, R. (2012), Proclus. An Introduction, Cambridge, Cambridge University Press.

Clark, G. (2007), "Augustine's Porphyry and the Universal Way of Salvation", in G. Karamanolis, A. Sheppard (eds), Studies on Porphyry, London, University of London, p. 127-140.

Clark, S., "Plotinus, Eriugena and the Uncreated Image", lecture in the Oxford Workshop, Eriugena's Christian Platonism and Its Sources in Ancient and Patristic Philosophy, ed. I.L.E. Ramelli, forthcoming in Studia Patristica.

Corrigan, K. (2000), "Platonism and Gnosticism: The Anonymous Commentary on the Parmenides: Middle or Neoplatonic?”, in J.D. Turner, R. Majercik (eds), Gnosticism and Later Platonism: Themes, Figures, and Texts, Atlanta (GA), Society of Biblical Literature, p. 141-177.

Coutts, J. (2017), The Divine Name in the Gospel ofJohn: Significance and Impetus, Tübingen, Mohr Siebeck.

Crouzel, H. (1956), "Origène et Plotin élèves d' Ammonios Saccas”, in Bulletin de littérature ecclésiastique 57, p. 193-214.

d'Hoine, P., Martijn, M. (eds) (2017), All from One: A Guide to Proclus, Oxford, Oxford University Press, 2017.

DePalma Digeser, E. (2012), A Threat to Public Piety: Christian, Platonists, and the Great Persecution, Ithaca (NY) / London, Cornell University Press, 2012.

Edwards, M. (2004), "Pagan and Christian Monotheism in the Age of Constantine", in M. Edwards, S. Swain (eds), Approaching Late Antiquity, Oxford, Oxford University Press, p. 211-234.

Edwards, M. (2015), "One Origen or Two? The Status Quaestionis", in Symbolae Osloenses Norwegian Journal of Greek and Latin Studies 89.1, p. 81-103.

Edwards, M. (2019), Aristotle and Early Christian Thought, London, Routledge.

Falcon, A. (2019), review of Edwards, Aristotle and Early Christian Thought, in Sehepunkte 19(9.2) http://www.sehepunkte.de/2019/og/33o99.html

Finamore, J. (2021), "Proclus and the Conjunction of Soul and Body", in S.S. Griffin, I.L.E. Ramelli (eds), Lovers of Souls and Lovers of Bodies: Philosophical and Religious Perspectives in Platonism, Cambridge (MA), Harvard University Press (in press). 
Frede, M. (1999), "Monotheism and Pagan Philosophy in Late Antiquity", in M. Frede, P. Athanassiadi (eds), Pagan Monotheism in Late Antiquity, Oxford, Oxford University Press, p. 41-68.

Gardner, D. (2018), “The Ambiguity of the 'One' in Plato's Parmenides”, in Méthexis 30.1, p. 36-59.

Gersh, S. (1978), From Iamblichus to Eriugena, Leiden, Brill, 1978 (Italian transl. Da Giamblico a Eriugena, Bari, Pagina, 2009).

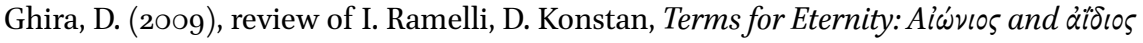
in Classical and Christian Author, in Maia 61, p. 732-734.

Hadot, P. (1960), "Citations de Porphyre chez Augustin", in Revue d'études augustiniennes et patristiques 6(3), p. 205-244.

Helmig, C., Steel, C. (2015), "Proclus", in Stanford Encyclopedia of Philosophy https:// plato.stanford.edu/entries/proclus/.

Hertz, G. (2016), “Un Dieu 'pas même indicible' (Elenchos, VII, 2O, 3): examen de la théologie basilidienne dans son rapport polémique aux théologies contemporaines", in B. Pouderon, A. Usacheva (eds), Dire Dieu. Les principes méthodologiques de l'écriture sur Dieu en patristique, Paris, Beauchesnes, p. 89-112.

Hirsch-Luipold, R., Görgemanns, H., von Albrecht, M. (eds) (20o9), Religiöse Philosophie und philosophische Religion der frühen Kaiserzeit, Tübingen, Mohr Siebeck.

Johnson, A.P. (2013), Religion and Identity in Porphyry of Tyre. The Limits of Hellenism in Late Antiquity, Cambridge, Cambridge University Press.

Karamanolis, G. (2016), "Early Christian Philosophers on Aristotle", in A. Falcon (ed.), Brill's Companion to the Reception of Aristotle in Antiquity, Leiden, Brill, p. 46o-479.

Kettler, F.H. (1979), "Origenes, Ammonios Sakkas und Porphyrius", in A.M. Ritter (ed.), Kerygma und Logos (Festschrift C. Andresen), Göttingen, Vandenhoek und Ruprecht, p. $322-328$.

Limone, V. (2018), “Origen's Explicit References to Aristotle and the Peripateticians", in Vigilae Christianae 72.4, p. 390-404.

Majercik, R. (1992), "The Existence-Life-Intellect Triad in Gnosticism and Neoplatonism", in Classical Quarterly 42, p. 475-488

Majercik, R. (2001), "Chaldean Triads in Neoplatonic Exegesis: Some Reconsiderations”, in Classical Quarterly 51, p. 265-296.

Markschies, C. (2007), Origenes und sein Erbe, Berlin, De Gruyter.

Marx, H. (2016), Spiritual Taxonomies and Ritual Authority: Platonists, Priests, and Gnostics in the Third Century c.E., Philadelphia (PE), University of Pennsylvania.

Menn, S. (1995), Plato on God as Nous, Carbondale (IL), Southern Illinois University.

Menn, S. (2013), "Plato's Soteriology?", in V. Adluri (ed.), Greek Religion: Philosophy and Salvation, Berlin, de Gruyter, p. 191-216.

Mitchell, S., van Nuffelen, P. (eds) (2010), One God. Pagan Monotheism in the Roman Empire, Cambridge, Cambridge University Press. 


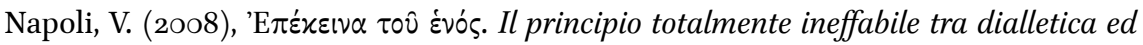
esegesi in Damascio, Catania, CUECM.

North, J. (2017), "The Religious History of the Roman Empire", in Oxford Research Encyclopedia of Religion, http://religion.oxfordre.com/view/10.1093/acrefore/978019934 o378.oo1.0oo1/acrefore-9780199340378-e-114.

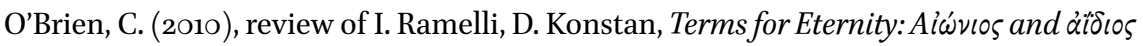
in Classical and Christian Author, in The Classical Review 6o.2, p. 390-391

Opsomer, J. (2001), "Proclus vs Plotinus on Matter (De mal. subs. 30-37)", in Phronesis 46, p. $154-188$.

Opsomer, J. (2018), "Proclus", in S. Cartwright, A. Marmodoro (eds), History of Mind and Body in Late Antiquity, Cambridge, Cambridge University Press, p. 129-150.

Pouderon, B., Usacheva, A. (eds) (2017), Dire Dieu: Principes méthodologiques de l'écriture sur Dieu en patristique, Paris, Beauchesne.

Ramelli, I.L.E. (2007a), Gregorio di Nissa sull'anima e la resurrezione, Milan, Bompiani.

Ramelli, I.L.E.(2007b), "Christian Soteriology and Christian Platonism. Origen, Gregory of Nyssa, and the Biblical and Philosophical Basis of the Doctrine of Apokatastasis", in Vigiliae Christianae 61.3, p. 313-356.

Ramelli, I.L.E. (2008a), "Philosophical Allegoresis of Scripture in Philo and Its Legacy in Gregory of Nyssa", in Studia Philonica Annual 2o, p. 55-99.

Ramelli, I.L.E. (2008b), “Origen's Exegesis of Jeremiah: Resurrection Announced throughout the Bible and its Twofold Conception", in Augustinianum 48, p. 59-78.

Ramelli, I.L.E. (2008c), “Origene ed il lessico dell'eternità", in Adamantius 14, p. 100-129. Ramelli, I.L.E. (2009a), “Origen, Patristic Philosophy, and Christian Platonism: ReThinking the Christianisation of Hellenism", in Vigilae Christianae 63, p. 217-263.

Ramelli, I.L.E. (2009b), Bardaișan of Edessa: A Reassessment of the Evidence and a New Interpretation, Piscataway (NJ), Gorgias Press.

Ramelli, I.L.E. (2011a), review of R. Hirsch-Luipold, H. Görgemanns, M. von Albrecht (eds), Religiöse Philosophie und philosophische Religion der frühen Kaiserzeit, in Anzeiger für die Altertumswissenschaft 64.3/4, p. 168-171.

Ramelli, I.L.E. (2011b), “Origen's Anti-Subordinationism and Its Heritage in the Nicene and Cappadocian Line", in Vigilae Christianae 65, p. 21-49.

Rdamelli, I.L.E. (2011c), "The Philosophical Stance of Allegory in Stoicism and its Reception in Platonism”, in International Journal for Classical Tradition 18, p. 335-371.

Ramelli, I.L.E. (2011d), "Origen the Christian Middle-Neoplatonist: New Arguments for a Possible Identification”, in Journal of Early Christian History 1.1, p. 98-130.

Ramelli, I.L.E. (2011e), "The Birth of the Rome-Alexandria Connection: The Early Sources on Mark and Philo, and the Petrine Tradition", in The Studia Philonica Annual 23, p. 69-95.

Ramelli, I.L.E. (2012a), "Origen, Greek Philosophy, and the Birth of the Trinitarian Meaning of Hypostasis", in The Harvard Theological Review, 105.3, p. 302-350. 
Ramelli, I.L.E. (2012b), "Philo as Origen's Declared Model. Allegorical and Historical Exegesis of Scripture", in Studies in Christian-Jewish Relations 7, p. 1-17.

Ramelli, I.L.E. (2012c), “The Dialogue of Adamantius: A Document of Origen's Thought? Part 1", in Studia Patristica 52, p. 71-98; 56.4 (2013) 227-273.

Ramelli, I.L.E. (2013a), The Christian Doctrine of Apokatastasis. A Critical Assessment from the New Testament to Eriugena, Leiden, Brill.

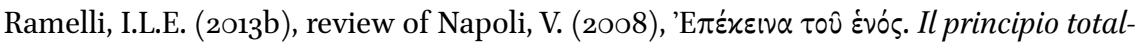
mente ineffabile tra dialletica ed esegesi in Damascio in Stylos 22, p. 250-255.

Ramelli, I.L.E. (2013c), “Origen and Augustine: A Paradoxical Reception”, in Numen 6o, p. $280-307$.

Ramelli, I.L.E. (2013d), "Harmony between arkhe and telos in Patristic Platonism and the Imagery of Astronomical Harmony Applied to the Apokatastasis Theory", in International Journal of the Platonic Tradition 7.1, p. 1-49.

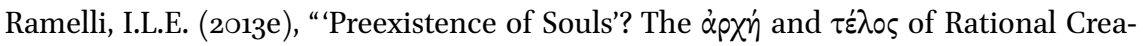
tures in Some Origenian Authors", in Studia Patristica LVI.4, p. 167-226.

Ramelli, I.L.E. (2013f), "The Dialogue of Adamantius: A Document of Origen's Thought? Part 2", in Studia Patristica 56.4, p. 227-273.

Ramelli, I.L.E. (2014a), "Monotheism", in A. Di Berardino, T.C. Oden, J.C. Elowsky, J. Hoover (eds), Encyclopedia of Ancient Christianity. Vol. 2, Downers Grove (IL), InterVarsity Press, p. 829-833.

Ramelli, I.L.E. (2014b), "The Stoic Doctrine of Oikeiosis and its Transformation in Christian Platonism", in Apeiron 47, p. 116-140.

Ramelli, I.L.E. (2014c), “Alexander of Aphrodisias: A Source of Origen's Philosophy?”, in Philosophie Antique 14, p. 237-29o.

Ramelli, I.L.E. (2014d), The Stoic Doctrine of Oikeiosis and its Transformation in Christian Platonism, in Apeiron 47.1, p. 1-25.

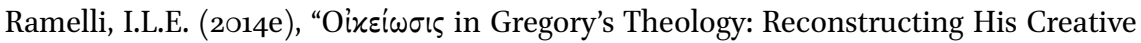
Reception of Stoicism," in J. Leemans, M. Cassin (eds), Gregory of Nyssa: Contra Eunomium III. An English Translation with Commentary and Supporting Studies. Proceedings of the 12th International Colloquium on Gregory of Nyssa (Leuven, 1417 September 2010), Leiden, Brill, 2014, p. 643-659.

Ramelli, I.L.E. (2014f), “Iamblichus, De anima 38 (66.12-15 Finamore-Dillon): A Resolving Conjecture?", in Rheinisches Museum 157, p. 106-111.

Ramelli, I.L.E. (2014g), "Philo's Doctrine of Apokatastasis: Philosophical Sources, Exegetical Strategies, and Patristic Aftermath", in The Studia Philonica Annual 26, p. $29-55$.

Ramelli, I.L.E. (2015a), "Proclus and Christian Neoplatonism: Two Case Studies", in M. Knežević (ed.), The Ways of Byzantine Philosophy, Alhambra (CA), Sebastian Press, p. 37-70.

Ramelli, I.L.E. (2015b), Tempo ed eternità in età antica e patristica. Grecità, Ebraismo e Cristianesimo, Assisi, Cittadella. 
Ramelli, I.L.E. (2015c), Evagrius' Kephalaia Gnostika, Atlanta (GA), Society of Biblical Literature, 2015 .

Ramelli, I.L.E. (2015d), "Evagrius Ponticus, the Origenian Ascetic (and not the Origenistic 'Heretic')", in J.A. McGuckin (ed.), Orthodox Monasticism, Past and Present, Piscataway (NJ), Gorgias Press, p. 147-205.

Ramelli, I.L.E. (2016a), "Bardaisan: a Christian Middle Platonist from Edessa and his Reading of Scripture in the Light of Plato," in C. Horn, S.H. Griffith (eds), Biblical \& Qur'ānic Traditions in the Middle East, Warwick, RI, Abelian Academic, p. 215238.

Ramelli, I.L.E. (2016b), “Origen's Allegoresis of Plato's and Scripture's Myths," in N.P. Desrosiers, L.C. Vuong (eds), Religious Competition in the Greco-Roman World, Atlanta (GA), Society of Biblical Literature, p. 85-106.

Ramelli, I.L.E. (2017a), "Proclus and Apokatastasis", in D. Butorac, D. Layne (eds), Proclus and His Legacy, Berlin, de Gruyter, p. 95-122.

Ramelli, I.L.E. (2017b), review of M.B. Simmons, Universal Salvation in Late Antiquity: Porphyry of Tyre and the Pagan-Christian Debate in The Classical Journal http://cj .camws.org/sites/default/files/reviews/2017.05.02\%20Ramelli\%20on\%2OSimmon s.pdf

Ramelli, I.L.E. (2017c), “Origen and the Platonic Tradition", in Religions 8(2).21 https:// www.mdpi.com/180006

Ramelli, I.L.E. (2017d), “Gregory Nyssen's and Evagrius' Biographical and Theological Relations: Origen's Heritage and Neoplatonism”, in I. Ramelli, in collaboration with K. Corrigan, G. Maspero, M. Tobon (eds), Evagrius between Origen, the Cappadocians, and Neoplatonism, Leuven, Peeters, p. 165-231.

Ramelli, I.L.E. (2018a), review of B. Pouderon, A. Usacheva (eds), Dire Dieu: Principes méthodologiques de l'écriture sur Dieu en patristique in Journal of Theological Studies 69, p. 810-814.

Ramelli, I.L.E. (2018b), "Origen”, in A. Marmodoro, S. Cartwright (eds), A History of Mind and Body in Late Antiquity, Cambridge, Cambridge University Press, p. 245-266.

Ramelli, I.L.E. (2018c), "Philo as One of the Main Inspirers of Early Christian Hermeneutics and Apophatic Theology", in Adamantius 24, p. 276-292.

Ramelli, I.L.E. (2018d), "Mysticism and Mystic Apophaticism in Middle and Neoplatonism across Judaism, 'Paganism' and Christianity," in A. Wilke (ed.), Constructions of Mysticism as a Universal. Roots and Interactions Across the Borders, Wiesbaden, Harrassowitz.

Ramelli, I.L.E. (2018e), "The Role of Allegory, Allegoresis, and Metaphor in Paul and Origen", in Journal of Greco-Roman Christianity and Judaism 14, p. 130-157.

Ramelli, I.L.E. (2018f), “Origen to Evagrius”, H. Tarrant, D. Baltzly, D.A. Layne, F. Renaud (eds), Brill's Companion to the Reception of Plato in Antiquity, Leiden, Brill, p. 271291. 
Ramelli, I.L.E. (2018g), "Gregory of Nyssa”, in A. Marmodoro, S. Cartwright (eds), A History of Mind and Body in Late Antiquity, Cambridge, Cambridge University Press, p. $283-305$.

Ramelli, I.L.E. (2018h), "Gregory of Nyssa on the Soul (and the Restoration): From Plato to Origen", in A. Marmodoro, N. McLynn (eds), Exploring Gregory of Nyssa: Historical and Philosophical Perspectives, Oxford, Oxford University Press, p. 110141.

Ramelli, I.L.E. (2019a), “The reception of Plato's Parmenides in Origen of Alexandria," lecture, provisional version published by International Plato Society https:// platosociety.org/event/ilaria-ramelli-the-reception-of-platos-parmenides-in-orige n-of-alexandria/ partially published as "Parmenides' Philosophy through Plato's Parmenides in Origen of Alexandria”, in G. Cornelli et al. (eds), Eleatic Ontology: Origin and Reception, 1.6: Eleatic Ontology in the Hellenistic Period to Late Antiquity, forthcoming.

Ramelli, I.L.E. (2019b), “Origen's Critical Reception of Aristotle: Some Key Points and Aftermath in Christian Platonism”, in M. Knezevic (ed.), Aristotle in Byzantium, Alhambra (CA), Sebastian Press, p. 1-44.

Ramelli, I.L.E. (2019c), "Philo's Dialectics of Apophatic Theology, His Strategy of Differentiation, and His Impact on Patristic Exegesis and Theology", in Philosophy 3, p. 36-92.

Ramelli, I.L.E. (2019d), A Larger Hope?, Volume 1: Universal Salvation from Christian Beginnings to Julian of Norwich, Eugene (OR), Cascade Books.

Ramelli, I.L.E. (202O), "Sources and Reception of Dynamic Unity in Middle and Neoplatonism, 'Pagan' and Christian"Journal of the Bible and Its Reception 7, p. 31-66.

Ramelli, I.L.E. (2021), “Gregory of Nyssa's Purported Criticism of Origen's Purported Doctrine of the Preexistence of Souls," in S.S. Griffin, I.L.E. Ramelli (eds), Lovers of Souls and Lovers of Bodies: Philosophical and Religious Perspectives in Platonism, Cambridge (MA), Harvard University Press (in press).

Ramelli, I.L.E. (forthcoming- a), "La triade Ousia-Dynamis-Energeia in Gregorio di Nissa e nei Cappadoci: Paralleli filosofici e ascendenze origeniane”, in G. D'Onofrio, R. De Filippis, E. Mainoldi (eds), La triade dell'Essere. Essenza-Potenza-Atto nel pensiero tardo-antico, medievale e rinascimentale, Turnhout, Brepols.

Ramelli, I.L.E. (forthcoming- b), “The Logos/Nous One-Many between 'Pagan' and Christian Platonism, Part II", in Studia Patristica: 102 (2021), p. 11-44.

Ramelli, I.L.E. (forthcoming- d), "Origen and Porphyry: Continuity and Polemics between Psychology and Eschatology: Preliminary Remarks", in M. Knežević (ed.), Philosophos-Philotheos-Philoponos: Studies and Essays as Charisteria in Honor of Professor Bogoljub Šijaković on the Occasion of His 65th Birthday, Belgrade / Podgorica, Gnomon Centre for the Humanities.

Ramelli, I.L.E. (forthcoming- e), “'Pagan’ and Christian Platonism in Dionysius: The 
Double-Reference Scheme and Its Meaning", in S. Klitenic Wear, F. Lauritzen (eds), Byzantine Platonists 284-1453, Washington, The Catholic University of America Press, p. 92-112.

Ramelli, I.L.E. (forthcoming-g), “Origen, Evagrius and Dionysius”, in M. Edwards, D. Pallis, G. Steiris (eds), The Oxford Handbook of Dionysius the Areopagite, Oxford, Oxford University Press.

Ramelli, I.L.E. (forthcoming- h), Eriugena's Christian Platonism and Its Sources in Ancient and Patristic Philosophy, Leuven, Peeters.

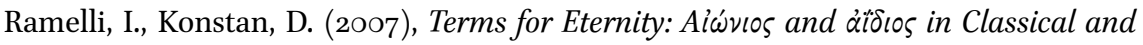
Christian Authors, Piscataway (NJ), Gorgias Press (new editions 2011 and 2013).

Reydams-Schils, G.J. (ed.) (2003), Plato's Timaeus as Cultural Icon, Notre Dame (IN), University of Notre Dame.

Rüpke, J. (2018), Pantheon: A New History of Roman Religion, trans. David Richardson, Princeton (NJ), Princeton University Press.

Saffrey, H.D. (2012), Porphyre: Lettre à Anébon l'égyptien, Paris, Les Belles Lettres.

Simmons, M.B. (2006), "Via universalis animae liberandae: The Pagan-Christian Debate on Universalism in the Later Roman Empire", in Studia Patristica 42, p. 319-324.

Simmons, M.B. (2009), "Porphyrian Universalism: A Tripartite Soteriology and Eusebius's Response", in The Harvard Theological Review 102.2, p. 169-192.

Simmons, M.B. (2015), Universal Salvation in Late Antiquity: Porphyry of Tyre and the Pagan-Christian Debate, Oxford, Oxford University Press.

Smith, A. (1974), Porphyry's Place in the Neoplatonic Tradition. A Study in Post-Plotinian Neoplatonism, The Hague, Martinus Nijhoff, p. 136-141.

Smith, A. (1992), "Porphyrian Studies since 1913", in W. Haase (ed.), Aufstieg und Niedergang der Römischen Welt 2.36/2, Berlin, De Gruyter, p. 717-773.

Stefaniw, B. (2010), "Exegetical Curricula in Origen, Didymus, and Evagrius: Pedagogical Agenda and the Case for Neoplatonist Influence", in Studia Patristica 44, p. 281295 .

Tarrant, H. (2017), "Plotinus, Origenes and Ammonius on the King", in A. Klostergaard Petersen, G. van Kooten (eds), Religio-Philosophical Discourses Within the GrecoRoman, Jewish and Early Christian World, Leiden, Brill, p. 323-337.

Tarrant, H. (2017), "Plotinus, Origenes, and Ammonius on the 'King', in A.K. Petersen, G.H. van Kooten (eds), Religio-Philosophical Discourses in the Mediterranean World. From Plato, through Jesus, to Late Antiquity, Leiden, Brill, p. 323-337.

Tempelis, E., Terezis, C. (2017), Proclus on the Transition from Metaphysical Being to Natural Being, Piscataway (NJ), Gorgias Press.

Tzamalikos, P. (2016), Anaxagoras, Origen, and Neoplatonism: The Legacy of Anaxagoras to Classical and Late Antiquity, 1-2, Berlin, De Gruyter, 2016.

van Riel, G. (2013), Plato's Gods, Farnham, Ashgate, 2013. 